\title{
Safety of the fungal workhorses of industrial biotechnology: update on the mycotoxin and secondary metabolite potential of Aspergillus niger, Aspergillus oryzae, and Trichoderma reesei
}

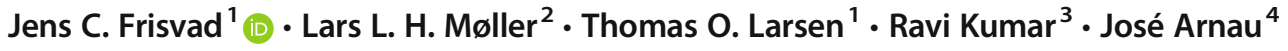

Received: 12 July 2018 /Revised: 28 August 2018 / Accepted: 29 August 2018 / Published online: 6 October 2018

(C) The Author(s) 2018

\begin{abstract}
This review presents an update on the current knowledge of the secondary metabolite potential of the major fungal species used in industrial biotechnology, i.e., Aspergillus niger, Aspergillus oryzae, and Trichoderma reesei. These species have a long history of safe use for enzyme production. Like most microorganisms that exist in a challenging environment in nature, these fungi can produce a large variety and number of secondary metabolites. Many of these compounds present several properties that make them attractive for different industrial and medical applications. A description of all known secondary metabolites produced by these species is presented here. Mycotoxins are a very limited group of secondary metabolites that can be produced by fungi and that pose health hazards in humans and other vertebrates when ingested in small amounts. Some mycotoxins are species-specific. Here, we present scientific basis for (1) the definition of mycotoxins including an update on their toxicity and (2) the clarity on misclassification of species and their mycotoxin potential reported in literature, e.g., A. oryzae has been wrongly reported as an aflatoxin producer, due to misclassification of Aspergillus flavus strains. It is therefore of paramount importance to accurately describe the mycotoxins that can potentially be produced by a fungal species that is to be used as a production organism and to ensure that production strains are not capable of producing mycotoxins during enzyme production. This review is intended as a reference paper for authorities, companies, and researchers dealing with secondary metabolite assessment, risk evaluation for food or feed enzyme production, or considerations on the use of these species as production hosts.
\end{abstract}

Keywords Safety $\cdot$ Mycotoxins $\cdot$ Secondary metabolites $\cdot$ Industrial enzymes

\section{Introduction}

Earlier reviews on the safety of Aspergillus niger, Aspergillus oryzae, and Trichoderma reesei have been published (Schuster et al. 2002; Tanaka et al. 2002; Barbesgaard et al.

Jens C. Frisvad

jcf@bio.dtu.dk

1 Department of Biotechnology and Biomedicine (DTU

Bioengineering), Technical University of Denmark, Søltofts Plads, B. 221, 2800 Kongens Lyngby, Denmark

2 Department of Product Safety, Novozymes A/S, Krogshoejvej 36, 2880 Bagsvaerd, Denmark

3 Department of Genomics and Bioinformatics, Novozymes Inc., 1445 Drew Ave., Davis, CA 95618, USA

4 Department of Fungal Strain Technology and Strain Approval Support, Novozymes A/S, Krogshoejvej 36, 2880 Bagsvaerd, Denmark
1992; Jørgensen 2007; Blumenthal 2004), but since these reviews were written, much progress has been made in the taxonomy, toxicology, natural product chemistry, genomics, genetics, and molecular biology of these fungi.

There is a clear distinction between mycotoxins and other secondary metabolites with attractive properties for diverse applications. Fungal species containing industrial strains have the potential to produce a rather limited number of compounds that are toxic to vertebrates (mycotoxins) and a large variety of other compounds that can display anticarcinogenic or antimicrobial activity, antioxidant activity, be pigments, etc. (Mushtaq et al. 2018). A clear definition of mycotoxin and secondary metabolite is presented here to provide a clear basis for the consideration of safety. The fungal strains that represent the workhorses of industrial biotechnology have a long and extensively documented history of safe use for food and feed applications. Strains belonging to the Aspergillus species A. niger and A. oryzae have been used for fermentation of food for more than 2 millennia and to manufacture food 
enzymes for over 50 years, while strains of Trichoderma reesei have been used safely for decades in enzyme production. Hundreds of enzymes produced in these species are considered as safe by regulatory authorities. Furthermore, mycotoxins and other secondary metabolites are not produced during the controlled, industrially relevant growth conditions where nutrients are not limited and where there is no growth challenge by any other microorganism.

This report includes a comprehensive update of the current knowledge about the mycotoxin and the promising secondary metabolite potential of these industry relevant fungal species. We have considered all published work and have critically evaluated the validity of the data and the accuracy of the taxonomic identification in each case. Consequently, not all publications have been included herein. The report is divided into three sections (taxonomy, mycotoxins, and secondary metabolite potential) for each species.

\section{Taxonomy of Aspergillus niger, Aspergillus oryzae, and Trichoderma reesei}

Traditional identification of fungal species relied on microscopic and macroscopic morphological traits, e.g., sporulation structures and other phenotypic features like growth and colony features (see Fig. 1 for examples of A. niger, A. oryzae, and its close relative Aspergillus flavus, together with $T$. reese $i$ ). In the last decades, taxonomical classification aided by secondary metabolite profiles has also proven successful (Frisvad and Larsen 2015; Samson et al. 2014). More recently, the use of diagnostic gene sequences like rRNA and, later, the availability of whole genome sequences, have enabled direct comparison of different species at the nucleotide level, throughout the genome. In fact, rDNA-derived ITS sequences are recommended as one of the main "barcodes" for species identification (Samson et al. 2014). However, at least in some Aspergillus clades, there is limited variation in, e.g., ITS sequences, requiring the use of additional barcodes like calmodulin or $\beta$-tubulin (Samson et al. 2014). The level of resolution of these molecular techniques provides new ways to investigate what defines the species boundaries (Vesth et al. 2018). Still, differences in DNA sequences alone cannot always provide a biological understanding. Also, the profiles of secondary metabolites are species-specific (Frisvad and Larsen 2015) and thereby consistent with phylogenetic relationships in fungi (Larsen et al. 2005; Kocsubé et al. 2016). When taxonomical identification is required, it is therefore advantageous to combine the accumulated knowledge on morphological, physiological, and molecular characteristics. Taxonomical classification of A. niger, $A$. oryzae, and $T$. reesei together with relevant related species is described in the following texts.

\section{Aspergillus niger}

Aspergillus niger is placed within the Aspergillus niger clade in the Aspergillus section Nigri (Varga et al. 2011a). The species is well-circumscribed, but it has a sibling species, with the same properties, called Aspergillus welwitschiae (Hong et al. 2013a). The latter species shares all morphological, physiological, and chemical characters with A. niger (Fig. 1), and the two species can only be distinguished by sequencing preferably one of the secondary bar-coding genes (Hong et al. 2013b). The DNA barcodes of Aspergillus welwitschiae are as follows: ITS (internally transcribed spacer regions and the $5.8 \mathrm{~S}$ of the ribosomal gene): FJ629340; BenA ( $\beta$-tubulin): FJ629291; CaM (calmodulin): KC480196, while A. niger has the following barcodes: ITS: EF 661186; BenA ( $\beta$-tubulin): EF661089; CaM (calmodulin): EF661154; RPB2 (RNA polymerase B2: EF661058). Different strains of Aspergillus niger have been genome-sequenced (see Baker 2006; Pel et al. 2007; Andersen et al. 2011).

Other species closely related to A. niger are Aspergillus neoniger, Aspergillus tubingensis, Aspergillus vadensis, Aspergillus luchuensis, Aspergillus encalypticola, Aspergillus costaricaensis, and Aspergillus piperis, but it is mostly A. luchuensis (formerly Aspergillus acidus or Aspergillus foetidus var. acidus), A. vadensis, and A. tubingensis that are used in the industry. In some cases, the latter have been misidentified as $A$. niger, and A. niger is by far most commonly used species in the industry (Frisvad et al. 2011). A. luchuensis is found in fermented Puerh tea (Mogensen et al. 2009) and is used often for koji production (also under the names Aspergillus kawachii and Aspergillus awamori) (Fujimoto et al. 1993; Hong et al. 2013a; Fujii et al. 2016). A. niger sensu stricto is the most commonly used species in biotechnology (Andersen et al. 2011; Frisvad et al. 2011). An often examined typical strain of $A$. niger is ATCC 1015.

Unlike the situation in A. flavus, which has a taxonomically accepted domesticated form A. oryzae, the domesticated form of A. niger, A. awamori (Nakazawa 1907, Sakaguchi et al. 1951; Raper and Fennell 1965; Murakami 1979; AlMusallam 1980), has not been accepted as a valid name, probably because of a mistaken neotypification. Perrone et al. (2011) used the name A. awamori for a taxon that was isolated from Welwitschia mirabilis, but since the ex-type isolate (CBS 557.65) was not from a koji environment, that species was renamed $A$. welwitschiae by Hong et al. (2013a). Other names such as Aspergillus usamii and A. kawachii have also been used for domesticated forms of A. niger or A. luchuensis (Hong et al. 2013b). However, none of these names have been officially taken up for the domesticated form of $A$. niger. The names Aspergillus phoenicis and Aspergillus ficuum predate $A$. niger and have therefore been rejected, and the name $A$. niger officially conserved because of the economical importance of the latter species (Kozakiewicz et al. 1992). 
Fig. 1 Macroscopic characteristics of 7-day old fungal species growing on solid medium (CYA). a Aspergillus niger; b A. oryzae; c A. flavus; d

Trichoderma reesei (Photo:

Birgitte Andersen)
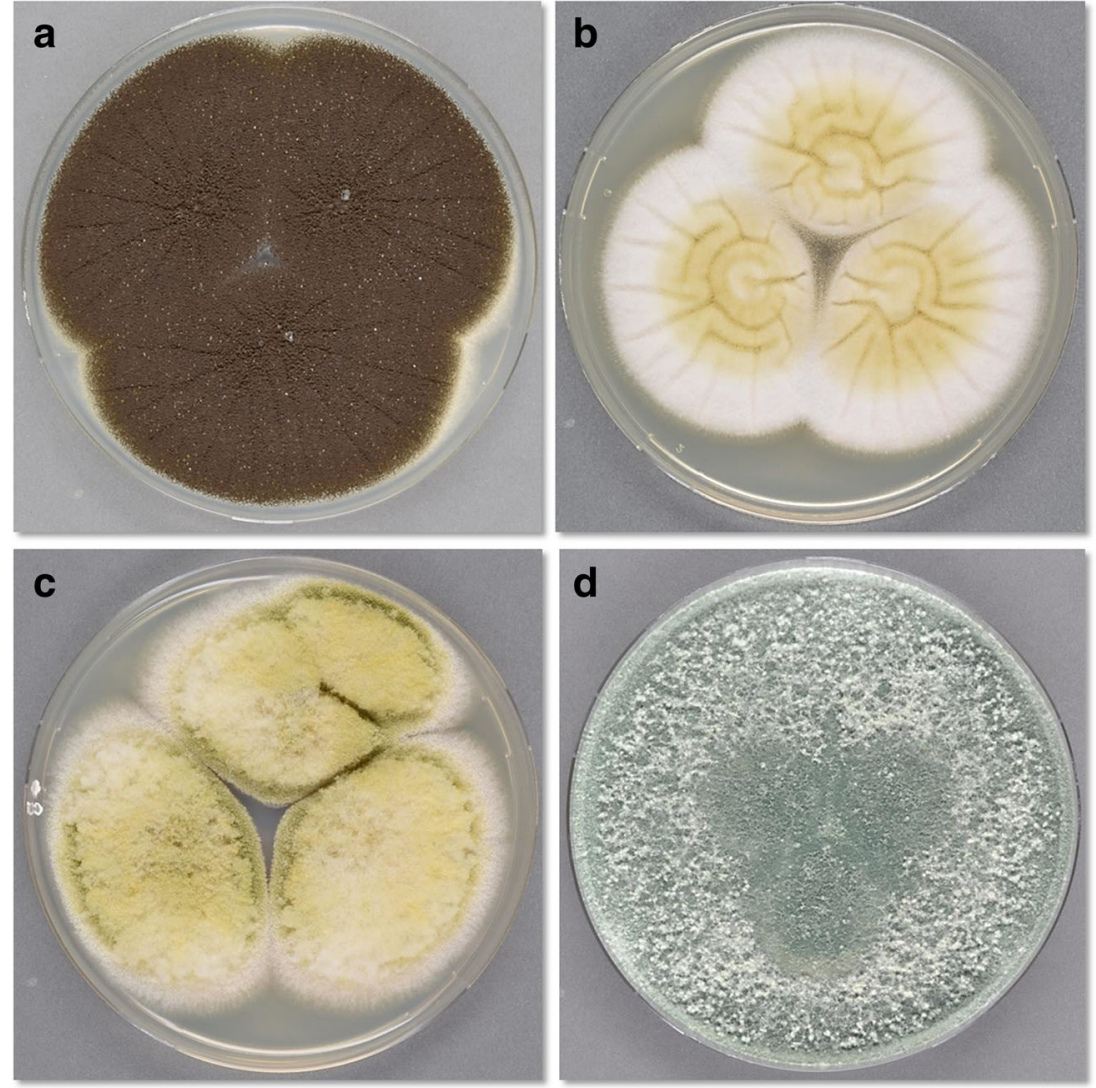

Average nucleotide identity (ANI) has become the gold standard for taxonomic confirmation of prokaryotes. Two species having $>95 \%$ ANI are considered the same species (Rodriguez and Konstantinidis 2014). Although ANI is not widely used in eukaryotes and there are no studies done to layout an ANI-based species framework in fungi, ANI values can still be used to determine the relatedness of two strains or species and can give a better resolution of phylogenetic tree-based inferences (Goris et al. 2007). ANI can also discriminate between closely related populations, and it provides a higher resolution than other sequence analyses, at least in bacteria (Rodriguez and Konstantinidis 2014).

We performed comparative genomics within species of the Nigri clade for which the genome sequence is available using ANI that showed a relatively high identity ( $85 \%$ or higher) between different species in this clade, while a lower level ( $76 \%$ ) was obtained when comparing to species outside the clade like A. oryzae or Aspergillus nidulans (Table 1). Remarkably, a higher ANI was obtained when comparing $A$. tubingensis and A. luchuensis ( 93\%) and a slightly lower ANI when comparing $A$. tubingensis with $A$. vadensis or $A$. luchuensis with $A$. vadensis ( 92\%). These three species appear to be more closely related (Table 1), and they all produce asperazines (Nielsen et al. 2009). A phylogenetic tree based on the above-mentioned genome comparison displays the closer relationship between these three species and the clustering of A. niger and Aspergillus brasiliensis (Fig. 2).

Recently, wild-type $A$. niger has been considered as a class 2 microorganism by the German authorities (BAUA see previous texts) because of its potential mycotoxin production and pathogenicity to humans and animals. It is important to discriminate between (1) mycotoxin production as a health hazard during food manufacture and spoilage and corn silage and (2) the growing number of reports of opportunistic pathogens that have resulted in disease, normally in immunocompromised patients. In fact, the baker's yeast (Saccharomyces cerevisiae) can also be considered as a pathogen since it has been associated with disease in severely immunocompromised patients. Perhaps the concept of what constitutes a "pathogen" needs a comprehensive revision and it is not solely related to the taxonomy of the microbe (Casadevall and Pirofski 2003).

\section{Aspergillus oryzae}

A. oryzae is regarded by most taxonomists as the domesticated form of A. flavus (Blochwitz 1929; Wicklow 1984; Klich and Pitt 1988; Georgianna et al. 2009; Rokas 2009; Varga et al. 2011b; Gibbons et al. 2012; Houbraken et al. 2014; Frisvad et al. 2019). Wicklow (1984) claims that domestication (in rice fermentations) has resulted in the following phenotypic 
Table 1 Reciprocal average nucleotide identity (ANI, Goris et al. 2007) of relevant Aspergillus species. A standalone version of the software was downloaded from http://enve-omics.ce.gatech.edu/ani/. Pair-wise comparisons of different combinations were performed using $\mathrm{R}$ script and phyton programming

\begin{tabular}{|c|c|c|c|c|c|c|c|c|c|}
\hline Strain & $\begin{array}{l}\text { A. oryzae } \\
\text { A1560 }\end{array}$ & $\begin{array}{l}\text { A. oryzae } \\
\text { RIB40 }\end{array}$ & $\begin{array}{l}\text { A. flavus } \\
\text { NRRL3357 }\end{array}$ & $\begin{array}{l}\text { A. niger } \\
\text { CBS513.88 }\end{array}$ & $\begin{array}{l}\text { A. brasiliensis } \\
\text { CBS101740 }\end{array}$ & $\begin{array}{l}\text { A. tubingensis } \\
\text { CBS134. } 48\end{array}$ & $\begin{array}{l}\text { A. luchuensis } \\
\text { NBRC } 4314\end{array}$ & $\begin{array}{l}\text { A. vadensis } \\
\text { CBS } 113365\end{array}$ & $\begin{array}{l}\text { A. nidulans } \\
\text { FGSCA4 }\end{array}$ \\
\hline $\begin{array}{r}\text { A. oryzae } \\
\text { A1560 }\end{array}$ & $100.00 \mid 0.00$ & $99.94 \mid 0.85$ & $99.14 \mid 1.75$ & $77.77 \mid 5.76$ & $77.63 \mid 5.22$ & $77.46 \mid 5.48$ & $77.24 \mid 4.90$ & $77.20 \mid 5.08$ & $76.28 \mid 4.68$ \\
\hline $\begin{array}{l}\text { A. oryzae } \\
\text { RIB40 }\end{array}$ & $99.97 \mid 0.34$ & $100.00 \mid 0.00$ & $99.16 \mid 1.61$ & $79.00 \mid 7.19$ & $78.09 \mid 5.61$ & $77.95 \mid 5.64$ & $77.42 \mid 5.21$ & $77.60 \mid 5.39$ & $76.31 \mid 4.72$ \\
\hline $\begin{array}{l}\text { A. flavus } \\
\text { NRRL3357 }\end{array}$ & $99.18 \mid 1.52$ & $99.18 \mid 1.49$ & $100.00 \mid 0.00$ & $77.44 \mid 5.15$ & $77.51 \mid 5.02$ & $77.54 \mid 5.39$ & $77.41 \mid 4.99$ & $77.14 \mid 4.98$ & $76.28 \mid 4.72$ \\
\hline $\begin{array}{l}\text { A. niger } \\
\text { CBS513.88 }\end{array}$ & $77.84 \mid 6.01$ & $78.35 \mid 6.66$ & $77.45 \mid 5.31$ & $100.00 \mid 0.00$ & $85.67 \mid 5.18$ & $86.87 \mid 5.23$ & $86.78 \mid 5.19$ & $86.89 \mid 5.23$ & $77.02 \mid 4.95$ \\
\hline $\begin{array}{l}\text { A. brasiliensis } \\
\text { CBS101740 }\end{array}$ & $77.59 \mid 5.09$ & $77.61 \mid 5.14$ & $77.49 \mid 5.00$ & $85.67 \mid 5.18$ & $100.00 \mid 0.00$ & $85.18 \mid 5.13$ & $85.08 \mid 5.10$ & $85.17 \mid 5.13$ & $77.16 \mid 5.37$ \\
\hline $\begin{array}{l}\text { A. tubingensis } \\
\text { CBS134.48 }\end{array}$ & $77.43 \mid 5.41$ & $77.49 \mid 5.40$ & $77.53 \mid 5.40$ & $86.85 \mid 5.24$ & $85.17 \mid 5.14$ & $100.00 \mid 0.00$ & $93.25 \mid 4.44$ & $92.54 \mid 4.76$ & $76.91 \mid 4.95$ \\
\hline $\begin{array}{l}\text { A. luchuensis } \\
\text { NBRC } 4314\end{array}$ & $77.30 \mid 4.90$ & $77.53 \mid 5.33$ & $77.38 \mid 4.95$ & $86.77 \mid 5.19$ & $85.09 \mid 5.09$ & $93.28 \mid 4.39$ & $100.00 \mid 0.00$ & $92.12 \mid 4.63$ & $76.85 \mid 4.94$ \\
\hline $\begin{array}{l}\text { A. vadensis } \\
\text { CBS } 113365\end{array}$ & $77.10 \mid 5.04$ & $77.17 \mid 5.00$ & $77.12 \mid 4.98$ & $86.86 \mid 5.26$ & $85.16 \mid 5.13$ & $92.53 \mid 4.78$ & $92.07 \mid 4.72$ & $100.00 \mid 0.00$ & $77.04 \mid 4.93$ \\
\hline $\begin{array}{l}\text { A. nidulans } \\
\text { FGSCA4 }\end{array}$ & $76.30 \mid 4.73$ & $76.31 \mid 4.73$ & $76.25 \mid 4.72$ & $77.00 \mid 4.97$ & $77.15 \mid 5.35$ & $76.84 \mid 4.99$ & $76.79 \mid 4.95$ & $77.05 \mid 4.93$ & $100.00 \mid 0.00$ \\
\hline
\end{tabular}

differences: conidia in A. oryzae are smoother and slightly larger (to adapt to the rice habitat), amylase production is higher, the conidiophore stipes are longer, the mycelium is more floccose, and the conidium color en masse is light brownish green rather than yellow grass green as compared to A. flavus (Fig. 1). While there are no genotypic differences between A. oryzae and A. flavus (Thom and Church 1921; Raper and Fennell 1965; Murakami 1971; Christensen 1981; Pitt et al. 1983; Wicklow 1984; Klich and Pitt 1985, 1988; Geiser et al. 1998, 2000; Gibbons et al. 2012; Powell et al. 2008; Varga et al. 2011; Gilbert et al. 2018; Frisvad et al. 2019), there are several morphological and physiological differences between the two species as listed previously. Furthermore Aspergillus oryzae cannot produce aflatoxins, aspergillic acid, and flavimine, that are otherwise present in most strains of Aspergillus flavus (Thom and Church 1921;
Raper and Fennell 1965; Murakami 1971; Christensen 1981; Wicklow 1984; Klich and Pitt 1985, 1988; Pitt et al. 1983; Varga et al. 2011; Frisvad et al. 2018; Fig. 1). Klich and Mullaney (1987) were able to distinguish between strains of A. oryzae and A. flavus by DNA restriction enzyme fragment polymorphisms. Nearly all strains of A. flavus produce a bright orange reverse on the medium AFPA (Aspergillus flavus parasiticus agar), while A. oryzae strains produce a cream-colored reverse (Bothast and Fennell 1974; Hamsa and Ayres 1977; Pitt et al. 1983).

In accordance with this, genome sequencing of $A$. flavus (Nierman et al. 2015; Faustinelli et al. 2016) and strains of $A$. oryzae (Machida et al. 2005; Galagan et al. 2005; Umemura et al. 2012, 2013a,b; Zhao et al. 2012, 2013a,b, 2014a,b) have shown that these two species are very similar. Interestingly, the first sequenced strain of $A$. oryzae may be an A. flavus

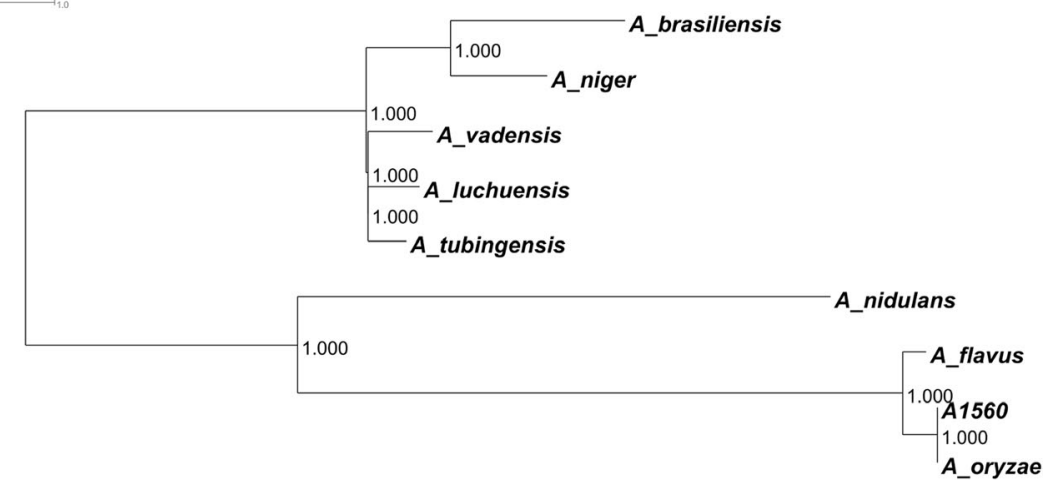

Fig. 2 Phylogram based on whole genome sequences of available Aspergillus species within the Nigri and Flavi clades. The phylogram was made using kSNP (version 3.1; Gardner et al. 2015) which computes a core SNP matrix from all the genomes and then executed
FastTree (Price et al. 2009) with the maximum likelihood option to compute the tree. The tree was then midpoint-rooted and rendered as a Phylogram using Dendroscope (Huson and Scornavacca 2012) 
"sensu stricto." The isolate RIB40 produces large globose sclerotia (Rank et al. 2012; Fig. 1) and was isolated from a broad bean, Kuriyamacho, Kyoto, Japan, in a field, not from a fermentation factory. Based on the first identification as $A$. oryzae var. brunneus, it has brownish conidia and, therefore, resemble $A$. oryzae. RIB40 does not produce aflatoxin as it contains disabling mutations in the gene cluster (Tominaga et al. 2006). It has been shown that A. flavus isolates gradually lose their ability to produce spores, sclerotia, and aflatoxinproducing capability after several serial transfers (Torres et al. 1980; Horn and Dorner 2001; Chang et al. 2007). The production of large globose sclerotia is characteristic for A. flavus sensu stricto (Geiser et al. 2000), and only few strains of $A$. flavus (for example NRRL 3251) produce small sclerotia (Hesseltine et al. 1970; Saito and Tsuruta 1993), while other strains with small sclerotia belong to the species Aspergillus minisclerotigenes, Aspergillus aflatoxiformans, Aspergillus austwickii, and Aspergillus cerealis (Varga et al. 2011; Frisvad et al. 2018). Overall, none of the characterized true A. oryzae isolates produce aflatoxins. For A. flavus, the situation is more complex since some isolates, including the extype strain (NRRL1957), do not produce aflatoxin. However, aflatoxin production has been shown for a large number of $A$. flavus including NRRL3357.

Genome sequencing has allowed several comparative studies to be carried out (Abe et al. 2006; Payne et al. 2006; Kobayashi et al. 2007; Rokas et al. 2007; Machida et al. 2008). A. oryzae is used extensively in enzyme production at industrial scale (Barbesgaard et al. 1992; Jørgensen 2007) and as a successful expression host for production of secondary metabolites (Sakai et al. 2008; Liu et al. 2015; Minami et al. 2016; He et al. 2018). In practice, sequence barcodes for $A$. oryzae include the following: (1) ITS (accession no. EF661560); (2) BenA ( $\beta$-tubulin, accession no. EF661483); (3) CaM (calmodulin accession no. EF661506); and (4) RPB2 (RNA polymerase B2, accession no. EF661438) and for $A$. flavus: (1) ITS: (AF027863); (2) BenA (EF661485); (3) CaM (EF661508); and RPB2 (EF661440). Remarkably, the barcodes are not sufficient to effectively separate $A$. flavus and $A$. oryzae. More elaborate molecular techniques are required to distinguish these species (Godet and Munaut 2010). ANI analysis showed a very high degree of sequence homology, well above $99 \%$, between RIB40 and other A. oryzae strains used in industrial enzyme production like A1560 (synonym IFO 4177), while a slightly lower percentage is observed when comparing $A$. flavus and A. oryzae (Table 1). The use of the \% identity between A. oryzae RIB40, A1560 or A. flavus NRRL3357 (99.9\% versus $99.1 \%$ ) does not allow a direct species discrimination based on ANI. Furthermore, ANI between A. oryzae and species from the Nigri section display an ANI value below $80 \%$. Members of the Nigri section display an ANI of $85 \%$ or higher. Lower ANI (approx. $75 \%$ ) is obtained when comparing either A. oryzae/A. flavus to
A. nidulans or species from the Nigri section to A. nidulans. Overall, as in the case of $A$. niger, the above-mentioned data demonstrate that genome homology data alone cannot be used for taxonomical purposes and need to be complemented by phenotypic properties.

\section{Trichoderma reesei}

Trichoderma reesei (anamorph) has also been named Hypocrea jecorina (teleomorph and holomorph), but with the new nomenclatural system used after 2011, Trichoderma reesei is considered the correct name for this fungus (Samuels et al. 1998; Samuels et al. 2012, Fig. 1). Most of the industrial strains have a single common ancestor, RUT-C30, which displays a blue-green color on solid medium (Fig. 1). The genome sequence has also been reported for this species (Martinez et al. 2008). The T. reesei type strain is QM6a.

\section{Mycotoxins are a very limited group of fungal secondary metabolites}

Fungal secondary metabolites can be defined as outward-directed, small differentiational molecules of restricted taxonomic distribution that are genetically encoded by clustered genes and accumulated and normally secreted. Secondary metabolites are a very heterogeneous chemical group of low molecular weight compounds that include antimicrobials, antioxidants, pigments, hormones, and metal chelators. A great number of these compounds have therefore a very significant potential application.

In general, any competition-selected fungal species has the potential to produce hundreds of individual secondary metabolites coded by up to 90 biosynthetic gene clusters (Clevenger et al. 2017; Lind et al. 2017). The major biosynthetic classes of secondary metabolites are polyketides, non-ribosomal peptides, terpenes, and shikimic acid-derived compounds, but many compounds are hybrids of these classes. The genes coding for the enzymes involved in the biosynthesis of these compounds are associated in gene clusters. The genomes of A. niger, A. oryzae, and T. reesei include 78,75 , and 27 gene clusters for secondary metabolite biosynthesis, respectively (Lind et al. 2015; Zeilinger et al. 2016; Wasil et al. 2018), although these numbers may vary depending on the strain and the software package used. Furthermore, each biosynthetic gene cluster may be responsible for the production of a large number of precursors, shunt products, and final products. For example Aspergillus oryzae was reported to produce many members (26) of the cyclopiazonic acid biosynthetic family of compounds (Liu et al. 2018), including cyclopazonic acids, speradines, cyclopiamides, and asporydines. With the development of new genome mining approaches (Kjærbølling et al. 2018) and algorithms such as antiSMASH (Blin et al. 2017), 
the prediction of secondary metabolite encoding gene clusters has become easier. On the other hand, the chemical modifications based on important accessory tailoring genes on the core structure of secondary metabolites may be more difficult to predict from sequences (Bertrand et al. 2018) and often require full structure elucidation. In this context, it is important to note that majority of gene clusters are not expressed under standard cultivation and that no fungal species synthesizes all potential secondary metabolites at any given time. As mentioned previously, production of secondary metabolites does not normally occur under production-relevant growth conditions where no species competition or nutrient starvation threat is used.

Mycotoxins are a very limited group of fungal secondary metabolites. Regarding biotechnology, mycotoxins are important if they pose a safety concern in the industrial application of fungi for enzyme or bulk metabolite production as well as in other areas like food spoilage and in building environments. There have been numerous definitions of the word mycotoxin (Bennett and Inamdar 2015; Taevernier et al. 2016), but a strict consensus definition that we endorse is the following: Mycotoxins are secondary metabolites genetically encoded by clustered genes and produced by fungi. These mycotoxins are acutely or chronically toxic and pose health hazards or death in humans and other vertebrates when acquired in small amounts via a natural route (orally, by inhalation, or via the skin). This definition is a combination of that of Jarvis and Miller (2005), Frisvad (2011), Bennett and Inamdar (2015), and Taevernier et al. (2016). Taevernier et al. (2016) suggested that a quantitative level of cell cytotoxicity on preferably human cell cultures with an $\mathrm{IC}_{50}$ (the concentration required for $50 \%$ of cell viability) of less than $1000 \mu \mathrm{M}$ could be used to determine whether a fungal secondary metabolite was considered a mycotoxin or not. We cannot accept this definition as such molecules may be cytotoxic, while not necessarily being toxic when acquired via a natural route. Earlier claims of mycotoxicity were based on other toxicity data, such as toxicity including cancerogenicity after intraperitoneal or subcutaneous injection (Dickens and Jones 1961; Cole and Cox 1981; Lu et al. 2017), but this too is not a natural route of intake. For example, patulin and penicillic acid were originally claimed to be cancerogenic based on subcutaneous injection (Dickens and Jones 1961), but Enomoto and Saito (1972) rightly mention that experimental production of cancer should be confirmed in animals by oral administration of mycotoxin.

The safe use of fungal strains is recognized in official classifications of biological agents into risk groups; e.g., BAUA (German Federal Institute for Occupational Safety and Health) classifies A. niger and A. oryzae as risk group 2 biological agents. Importantly, BAUA recognizes that strains belonging to these species may still be classified as risk group 1 biological agents if documentation of safety and/or history of safe use is provided.
In the following sections, we describe the mycotoxins that are potentially produced by the three industrial organisms and relevant related species. Only mycotoxins with a documented effect are described. All other secondary metabolites are described in the section on secondary metabolite potential and are not considered mycotoxins according to the definition herein.

\section{Mycotoxins potentially produced by Aspergillus niger}

Aspergillus niger has been claimed to produce a very large number of mycotoxins and other secondary metabolites (Table 2; Nielsen et al. 2009). Apart from a large number of volatiles and small organic acids (Wani et al. 2010; Priegnitz et al. 2015; Costa et al. 2016), A. niger sensu stricto can produce very few mycotoxins but a large number of other secondary metabolites. In many cases, fungi identified as A. niger were indeed $A$. tubingensis or other closely related species (Table 2).

\section{Fumonisins}

Fumonisins are strongly reduced polyketides with two added tricaballyllic acid groups and an amino group added from a non-ribosomal peptide. They are mycotoxins associated with multiple human and animal diseases, as they are produced in large amounts in cereals by common Fusarium species (Braun and Wink 2018; Cendoya et al. 2018). Fumonisins induce leukoencephalomalacia in horses, nephro- and hepatotoxicity in rodents, and pulmonary toxicity in pigs, and they have been classified as International Agency for Research on Cancer (IARC) type 2B carcinogens in humans (esophageal cancer) (Cendoya et al. 2018). However, Aspergillus niger and its sibling species $A$. welwitschiae (originally named $A$. awamori) also produce fumonisins of the $\mathrm{B}_{2}, \mathrm{~B}_{4}$, and $\mathrm{B}_{6}$ types (Frisvad et al. 2007; 2010) and may produce fumonisins in cereals and grapes (Logrieco et al. 2009; Mogensen et al. 2010; Munkvold et al. 2018). Several industrial strains have the capability to produce fumonisins (Frisvad et al. 2010; Han et al. 2017), so it is important to use strains that do not produce these mycotoxins. Current $A$. niger production strains have been developed that either have been selected due to the lack of fumonisin production or contain a deletion of the fumonisin gene cluster (unpublished results).

The impact of fumonisins on human health remains poorly understood (Voss and Riley 2013). It has been known for long that fumonisins are hepatotoxic, nephrotoxic, atherogenic (induces formation of plaque in arteries), immunosuppressive, and embryotoxic in experimental animal systems (Nair 1998). Structurally, fumonisin B1 shows similarity to the cellular sphingolipids, and this similarity has been shown to disturb the metabolism of sphingolipids leading to accumulation of sphinganine in cells and tissues. The cellular mechanisms behind fumonisin $\mathrm{B}_{1}$-induced toxicity include the induction of 
Table 2 Mycotoxins from Aspergillus niger (and its sibling species A. welwitschiae) (Nielsen et al. 2009)

\begin{tabular}{|c|c|c|}
\hline Mycotoxin & Reference & Comment \\
\hline Fumonisin $\mathrm{B}_{2}$ & Frisvad et al. $(2007,2011)$ & $\begin{array}{l}\text { This mycotoxin has been found in more than } 75 \% \text { of strains examined of } A \text {. } \\
\text { niger (Frisvad et al. 2011) }\end{array}$ \\
\hline Fumonisin $\mathrm{B}_{4}$ & Mogensen et al. (2010); Månsson et al. (2010) & \\
\hline Fumonisin $\mathrm{B}_{6}$ & Månsson et al. (2010) & \\
\hline Ochratoxin A & Abarca et al. (1994) & $\begin{array}{l}\text { This mycotoxins has been found in less than } 10 \% \text { of the strains of A. niger } \\
\text { examined (Frisvad et al. 2011) }\end{array}$ \\
\hline Oxalic acid & $\begin{array}{l}\text { Raistrick and Clark (1919); Yassin et al. } \\
\text { (2015) }\end{array}$ & Nearly all strains of $A$. niger produce oxalic acid \\
\hline
\end{tabular}

oxidative stress, apoptosis, and cytotoxicity, as well as alterations in cytokine expression (Stockmann-Juvala and Savolainen 2008). Mechanistically, the toxicity of fumonisin $\mathrm{B}_{2}$ and $\mathrm{B}_{3}$ is relatively poorly understood, but a comparison of the toxicities of fumonisin $\mathrm{B}_{1}, \mathrm{~B}_{2}$, and $\mathrm{B}_{3}$ individually and in combination has shown that all three are toxic, but with fumonisin $B_{1}$ being the most toxic of the three (Henry and Wyatt 2001).

\section{Ochratoxin}

Ochratoxin A (OTA) is a mycotoxin that is a common contaminant of a wide variety of food products. The molecular structure comprises a chlorinated polyketide dihydroisocoumarin ring linked to phenylalanine and, as shown in different producing fungal species, a polyketide synthase (PKS) is a major part of the biosynthetic pathway (Wang et al. 2016; Massi et al. 2016; Gallo et al. 2017; Gill-Serna et al. 2018). OTA inhibits protein synthesis and energy production, induces oxidative stress, cell apoptosis and necrosis, and DNA adduct formation, and is mostly recognized as a nephrotoxin (Heussner and Bingle 2015; Közégi and Poór 2016). It is classified as an IARC type B2 carcinogen in human beings.

\section{Oxalic acid}

Oxalic acid is a strong dicarboxylic acid. Oxalic acid is a reducing agent and its conjugate base, known as oxalate, is a chelating agent for metal cations. Typically, oxalic acid occurs as the dihydrate. Excessive ingestion of oxalic acid or prolonged skin contact can be dangerous. Oxalic acid is hepatotoxic, but it will only have a negative effect in quite high doses (Jahn 1977). Aspergillus niger infections are often accompanied with oxalosis (Kredics et al. 2008; Oda et al. 2013), and in one case, calcium oxalate produced by $A$. niger in the lungs caused hyperoxaluria in the kidneys (Vaideeswar and Sakhdeo 2009), so both kidneys and the liver can be affected. However, such cases are rare and will only happen in severely immunocompromised patients. Otomycoses are often caused by Aspergillus tubingensis rather than A. niger (Kredics et al. 2008).

\section{Improved safety of $A$. niger industrial strains}

As mentioned previously, A. niger has the potential to produce ochratoxin, fumonisin, and oxalic acid. Industrial strains have been developed by classical mutagenesis and by deletion of the genes involved in the biosynthesis (Susca et al. 2014).

\section{Mycotoxins from Aspergillus oryzae and A. flavus}

A. oryzae and its closely related species $A$. flavus can produce a very limited number of mycotoxins (Table 3 ). Their macroscopic similarity has contributed to a disparity of reports on the potential production of mycotoxins from either species. Mycotoxins produced by these species are described in the following texts with attention to knowledge about the potential production of these compounds by either species and reports that describe production in wrongly assigned species.

A. oryzae is a domesticated species originating probably from Aspergillus flavus, and the two species can not be distinguished by DNA sequence differences. Since A. oryzae is domesticated, it can only be expected to be found in fermentation environments. Any A. oryzae recovered in nature can only be found there if it has escaped such a fermentation plant, and based on its adaptation to the fermentation environment, it must be expected to be a poor competitor in cereals, oilseeds, and nuts, where A. flavus is a very competitive species (Wicklow 1984).

\section{Aflatoxins}

The aflatoxins ( $\mathrm{B}_{1}$ and $\mathrm{B}_{2}$ primarily) are polyketides that have been found in many strains of Aspergillus flavus, albeit not the culture ex type of A. flavus (Varga et al. 2009). Aflatoxin (AFL) has been reported from strains of Aspergillus oryzae, but these data are based on misidentified strains or misidentified mycotoxins or contaminated cultures (Varga et al. 2009). It has been shown that strains of Aspergillus oryzae 
Table 3 Mycotoxins reported from Aspergillus flavus and its domesticated form A. oryzae

\begin{tabular}{|c|c|c|}
\hline Metabolite & Reference & Comment \\
\hline $\begin{array}{l}\text { Aflatoxins } B_{1}, B_{2}, B_{2 \alpha}, B_{3} \text { and precursors } \\
\text { Aflatoxins } \mathrm{G}_{1} \text { and } \mathrm{G}_{2} \text { have been found in few } \\
\text { strains of } A \text {. flavus from South Korea. }\end{array}$ & $\begin{array}{l}\text { Hartley et al. (1963); Asao et al. (1963); van } \\
\text { der Merwe et al. (1963); van Dorp et al. } \\
\text { (1963); Asao et al. 1965; Burkhart and } \\
\text { Forgacs 1968; Dutton and Heathcote } \\
\text { (1968); Rodricks et al. (1968); Waiss et al. } \\
\text { (1968); Heathcote and Dutton (1969); } \\
\text { Holker et al. (1966); Cole et al. (1970); } \\
\text { Schroeder and Kelton (1975); Frisvad et al. } \\
\text { (2019); Rodríguez et al. (2012) }\end{array}$ & $\begin{array}{l}\text { Only found in some strains of Aspergillus } \\
\text { flavus and never found in A. oryzae }\end{array}$ \\
\hline $\begin{array}{l}\text { Cyclopiazonic acid and iso- } \alpha \text {-cyclopiazonic } \\
\text { acid, } \beta \text {-cyclopiazonic acid (= } \\
\text { bissecodehydrocyclopiazonic acid), } \\
\alpha \text {-cyclopiazonic acid imine, } \\
\text { 2-oxocyclopiazonic acid, cyclopiamide A, } \\
\text { cyclopiamide E \& H, speradine A, B, C, D, } \\
\text { E, F, H, I, 3-hydroxy-speradine A, cAATrp, } \\
\text { and asperorydine A-M }\end{array}$ & $\begin{array}{l}\text { Ohmomo et al. (1973) (misidentified as A. } \\
\text { versicolor; Domsch et al. 2007); Luk et al. } \\
\text { (1977); Orth (1977); Gallagher et al. } \\
\text { (1978); Tokuoda et al. (2008); Hu et al. } \\
\text { (2014a,b); Ma et al. (2015); Uka et al. } \\
\text { (2017); Liu et al. (2018) }\end{array}$ & $\begin{array}{l}\text { Cyclopiazonic acid has been found in several } \\
\text { strains of both } A \text {. flavus and } A \text {. oryzae }\end{array}$ \\
\hline$\beta$-Nitropropionic acid & $\begin{array}{l}\text { Bush et al. (1951); Nakamura and Shimoda } \\
\text { (1954); Iwasaki and Kosikowski (1973); } \\
\text { Orth (1977); He et al. (2016) }\end{array}$ & $\begin{array}{l}\text { Found in some strains of both A. oryzae and } \\
\text { A. flavus }\end{array}$ \\
\hline
\end{tabular}

sensu stricto cannot produce AFL, as a result of the lack of essential parts of the gene cluster, e.g., deletion of the aflR gene involved in induction of biosynthesis (Cary and Ehrlich 2006; Chang et al. 2007; Lee et al. 2006a,b; Tominaga et al. 2006; Takahashi et al. 2008, 2012; Kiyota et al. 2011; Hong et al. 2013b; Lee et al. 2014; Tao and Chung 2014). Therefore, AFL production can be excluded in $A$. oryzae sensu stricto. Furthermore, current industrial strains contain a deletion of the whole AFL gene cluster, providing additional safety in enzyme production. Type $G$ aflatoxins (aflatoxin $G_{1}$ and $G_{2}$ ) have rarely been reported from Aspergillus flavus. In some cases, the $\mathrm{G}$ type aflatoxins were produced by $A$. parasiticus and other species from section Flavi (Varga et al. 2011), rather than isolates that confidently can be allocated to A. flavus sensu stricto. Saldan et al. (2018) reported on aflatoxin $\mathrm{G}_{1}$ production by A. flavus ATCC 9643, but this strain may not be an A. flavus sensu stricto. Five Korean strains of $A$. flavus sensu stricto were reported to produce the G-type aflatoxins (Frisvad et al. 2019).

\section{Cyclopiazonic acids}

Cyclopiazonic acid (= $\alpha$-cyclopiazonic acid) $(\mathrm{CPA})$ is an indol tetrameric acid, hybrid polyketide/non-ribosomal peptide/ DMAT (dimethylallyl terpene unit) compound that was isolated from A. flavus originally by Luk et al. (1977) and Gallagher et al. (1978) but has since been found repeatedly in A. flavus (Varga et al. 2011b). It was originally isolated from a fungus identified as Penicillium cyclopium, but the strains of Penicillium-producing cyclopiazonic acid were Penicillium griseofulvum and Penicillium commune (Frisvad 1989; Frisvad et al. 2004). CPA has also been isolated repeatedly from Aspergillus oryzae (Orth
1977; Ohmomo et al. 1973, erroneously reported as $A$. versicolor; see Domsch et al. 2007; Frisvad 1989; Tokuoda et al. 2008; Shaaban et al. 2014). It is possible to remove the CPA gene cluster and thus avoid CPA production in biotechnological processes (Kato et al. 2011). A. oryzae and A. flavus can produce a large number of secondary metabolites related to CPA including iso- $\alpha$-cyclopiazonic acid, $\beta$-cyclopiazonic acid (= bissecodehydrocyclopiazonic acid), $\alpha$-cyclopiazonic acid imine, 2-oxocyclopiazonic acid, cyclopiamide (A), cyclopiamide E \& $\mathrm{H}$, speradine A, B, C, D, E, F, H, I, 3-hydroxy-speradine A, cAATrp, and asperorydine A-M (Ohmomo et al. 1973; Holzapfel et al. 1990; Hu et al. 2014a,b; Ma et al. 2015; Tokuoka et al. 2015; Xu et al. 2015; Uka et al. 2017; Liu et al. 2018) from A. oryzae and A. flavus, but speradine A is also produced by Aspergillus tamarii (Tsuda et al. 2003). Some of the strains reported as $A$. oryzae producing these tetramic acids have been isolated from marine sources, so they may in fact be $A$. flavus. However, the speradines are related to CPA, produced by many strains of both A. flavus and A. oryzae, and so speradines are not unlikely secondary metabolites in $A$. oryzae. There have been some problems with the naming of speradine $\mathrm{B}$ that is a different speradine in Penicillium dipodomyicola (Wang et al. 2015) than that from A. flavus, so some of the speradines need to be renamed.

\section{$\beta$-nitropropionic acid}

$\beta$-nitropropionic acid (BNP) is one of the real mycotoxins reported from authentic Aspergillus oryzae strains, but also from A. flavus strains (Bush et al. 1951; Nakamura and Shimoda 1954; Iwasaki and Kosikowski 1973; Orth 1977). 
It has caused sugarcane disease in children eating sugarcane infected with Nigrospora spp. that produce $\beta$-nitropropionic acid also (Liu et al. 1989; Ming 1995; Fu et al. 1995; Johnson et al. 2000; Fernagut et al. 2002; He et al. 1995). The genetic basis for production of BNP is not completely understood. Therefore, BNP levels are monitored in industrial enzyme productions.

\section{Mycotoxins from Trichoderma reesei}

It seems that chemotaxonomy is working excellently at the species level in Trichoderma (Kang et al. 2011). In the latter paper, T. reese $i$ was not included, and it is only few mycotoxins that are ascribed to T. reesei (Zeilinger et al. 2016) (Table 4). Reported mycotoxins from T. reesei (claimed to be a mutant of QM 9414 and called P-12) include trichodermin (Watts et al. 1988), but this ability to produce trichodermin by $T$. reesei has been rejected by Nielsen et al. (2005). The latter authors claimed that only Trichoderma brevicompactum can produce trichodermin, and possibly also Trichoderma arundinaceum (Zeilinger et al. 2016). There are also some trichothecene genes in Trichoderma gamsii and Trichoderma asperellum, but such genes have not been observed in T. reesei (Zeilinger et al. 2016). Also, the mycotoxin gliotoxin has been mentioned as a potential secondary metabolite in Trichoderma, because a gene cluster seems to be present in the genome of this fungus (Zeilinger et al. 2016). However, gliotoxin has never been detected in any culture of $T$. reesei (Martinez et al. 2008; Kubicek and Druzhinina 2016). T. reesei thus seems to be unable to produce mycotoxins.

\section{Toxicity of fungal mycotoxins relevant for $A$. niger, $A$. oryzae, and $T$. reesei}

Mycotoxins often affect different vertebrate species very differently. However, to enable a comparison of the relative toxicity of the mycotoxins potentially produced by $A$. niger, $A$. oryzae, and T. reesei, an overview of acute oral toxicity is provided (Table 5). In the enzyme industry, it is ensured that production strains based on A. niger, A. oryzae, and T. reesei do not produce mycotoxins when grown at large scale.

As shown previously, A. niger can produce the mycotoxins ochratoxin $\mathrm{A}$, fumonisins $\mathrm{B}_{2}, \mathrm{~B}_{4}$, and $\mathrm{B}_{6}$, and oxalic acid, and A. oryzae can produce the mycotoxins cyclopiazonic acid and $\beta$-nitropropionic acid, and T. reesei has not been convincingly shown to produce any mycotoxins.

\section{Improved safety of $A$. oryzae industrial strains}

As mentioned previously, A. oryzae strains are not able to produce aflatoxins due to the presence of disabling mutations in the gene cluster. Modern industrial strains have been developed that contain a large DNA deletion. This region includes the aflatoxin gene cluster and genes involved in the biosynthesis of cyclopiazonic acid (CPA, Christensen et al. 2000). Thus, during industrial enzyme production using strains derived from A1560 containing the chromosomal deletion, the presence of neither aflatoxin nor CPA is a concern.

\section{Secondary metabolite potential}

Fungal secondary metabolites are very diverse and include compounds with a wide range of applications (e.g., antibiotics, cancer treatment, immunosuppressing drugs, pigments, antioxidants).

Like many other fungi, Aspergillus species are capable of producing a very large number of drugs and drug-lead compounds. Among the best known for medical applications are the antibiotic penicillin to combat bacterial infections, the cholesterol-lowering mevinolin from Aspergillus terreus, the anticancer compound fumagillin from Aspergillus fumigatus, the antifungal echinocandin from Aspergillus pachycristatus and mulundocandin from Aspergillus mulundensis (Baltz et al. 2010; Houbraken et al. 2014; Zeiliger et al. 2015; Bills et al. 2016; Park et al. 2017a).

Fungi produce a large number of other secondary metabolites. Among them, fungal pigments such as polyketidederived azaphilones are used to add color and as antioxidants in food. Aspergillus species are used to produce yellow and brown pigments like fumigatin (Hanson 2008). Additionally, red pigments have been reported in, e.g., an A. flavus strain (Gurupavithra et al. 2017). Carotenes are important terpenoid pigments and antioxidants that are produced in many bacteria, fungi, algae, and plants. Interestingly, carotene is produced by few Aspergillus species and not by Trichoderma reesei (Avalos and Limon 2015).
Table 4 Mycotoxins reported from Trichoderma reesei

\begin{tabular}{lll}
\hline Metabolite & Reference & Comment \\
\hline Gliotoxin & Zeilinger et al. (2016) & $\begin{array}{l}\text { Actual gliotoxin production was not shown } \\
\text { Trichodermin }\end{array}$ \\
Watts et al. (1988); & $\begin{array}{c}\text { Culture could have been contaminated, but claimed to be derived } \\
\text { from QM 9414 as strain P-12; the claim that T. reesei produces } \\
\text { this mycotoxin may also be based on insufficient analytical } \\
\text { chemical methods }\end{array}$ \\
\hline
\end{tabular}




\section{Secondary metabolites described in A. niger}

Aspergillus niger has been claimed to produce a very large number of secondary metabolites (Table 6; Nielsen et al. 2009) including isoflavones which are actually plant metabolites (Umezawa et al. 1975; Nielsen et al. 2009). Apart from many volatiles and small organic acids (Wani et al. 2010; Priegnitz et al. 2015; Costa et al. 2016), A. niger sensu stricto can produce a variety of other secondary metabolites. In many cases, fungi identified as $A$. niger were indeed A. tubingensis or other closely related species (Table 2).

Asperazine and similar diketopiperazine heterodimers (Varoglu et al. 1997; Li et al. 2015) are not produced by $A$. niger, but consistently by $A$. tubingensis, $A$. vadensis, and $A$. luchuensis (Nielsen et al. 2009; Varga et al. 2011a; Hong et al. 2013). However, such re-identifications from $A$. niger to $A$. tubingensis mean that co-occurrring metabolites are not necessarily produced by A. niger. For example, an asperazineand asperazine A-producing isolate of A. tubingensis also produced cyclo(D-Phe-L-Trp), cyclo(L-Trp-L-Trp), walterolactone A, campyrones A-C, and kojic acid. According to our data, campyrones A-C are only produced by strains of A. tubingensis, and not by A. niger (but see Talontsi et al. 2013). Varoglu and Crews (2000) reported on asperic acid, hexylitaconic acid, malformin $\mathrm{C}$, and pyrophen production by an asperazine-producing fungus, which should also be identified as A. tubingensis. Several of these compounds have later been found in A. tubingensis including 2methylene-3-(6-hydroxyhexyl)-butanedioic acid, 2carboxymethyl-3-hexyl-maleic acid anhydride, 2-methylene3-hexyl-butanedioic acid (Almassi et al. 1994), demethylkotanin, TMC-256A1, TMC-256-C1 with an asperazine derivative (Ovenden et al. 2004), ergosterimide, 5,7-dihydroxy-2-[1-(4-methoxy-6-oxo-6H-pyran-2-yl)-2- phenylethylamino]-[1,4]naphthoquinone, asperamide A \& B, aspergillusol, asperpyrone $\mathrm{A} \& \mathrm{C}$, dianhydroauransperone $\mathrm{C}$, fonsecinone $A-D$, isopyrophen, nigerasperone $A-C$, aurasperone $\mathrm{A}-\mathrm{B}$, pyrophen, cyclo(L-Trp-L-Ile), cyclo(LTrp-L-Phe), cyclo(L-trp-L-Tyr) (Zhang et al. 2007a,b,c,d, 2010) asperic acid, campyrone A \& C, tubigenoid anhydride A, 2-carboxymethyl-3-hexylmaleic anhydride (Koch et al. 2014), 6-isovaleryl-4-methoxy-pyran-2-one, asperpyrone A, campyrone A and rubrofusarin B (Ma et al. 2016), nigerapyrone A-E and asnipyrone $\mathrm{A} \& \mathrm{~B}$, and nigerasterols (Liu et al. 2011, 2013), and malformin A1, cyclo(Gly-L-Pro) and cyclo(Ala-Leu) (Tan et al. 2015). Gibberellic acid reported from A. "niger" NRRL 2270 (Ates and Gökdere 2006) is rather produced by A. tubingensis (this strain has indeed been reidentified as such) (Frisvad et al. 2011). A strain of Pestalotiopsis theae was probably overgrown by a strain of A. tubingensis, and thus, further secondary metabolites from A. tubingensis include pastalazine A \& B and pestalamide A$\mathrm{C}$ together with asperazine, aspernigrin $\mathrm{A}$, and carbonarone $\mathrm{A}$ (see Ding et al. 2008).

A strain identified as A. niger was reported to produce asperiamide B and C (Wu et al. 2008), but it also produces the aflatoxin precursors averufin and nidurufin, so this strain was probably an A. flavus.

\section{Small acids of Aspergillus niger}

Oxalic acid, gluconic acid, and citric acid are small chelating organic acids derived from the citric acid cycle, but since they are secreted and accumulated may be characterized as secondary metabolites (Poulsen et al. 2012; Niu et al. 2016). These are by far the small organic acids produced in the highest amounts, but other acids can be produced by A. niger (Table 5).

Table 5 Acute oral toxicity of mycotoxins potentially expressed by Aspergillus niger, A. oryzae, and Trichoderma reesei

\begin{tabular}{|c|c|c|c|c|}
\hline \multirow[t]{2}{*}{ Species } & \multirow[t]{2}{*}{ Metabolite } & \multicolumn{2}{|c|}{ LD50 (acute oral toxicity, mg/kg) } & \multirow[t]{2}{*}{ Reference } \\
\hline & & Rat & Mouse & \\
\hline \multirow[t]{4}{*}{ Aspergillus niger } & $\begin{array}{l}\text { Fumonisin B2 } \\
\text { Fumonisin B4 }\end{array}$ & $>46.4^{\mathrm{a}}$ & - & McKean et al. (2006) \\
\hline & Fumonisin B6 & & & \\
\hline & Oxalic acid & 375 & - & Vernot et al. (1977) \\
\hline & Ochratoxin A & 20 & 46 & $\begin{array}{l}\text { Purchase and Theron (1968) } \\
\text { Kayoko (1985) }\end{array}$ \\
\hline \multirow[t]{3}{*}{ Aspergillus oryzae } & Cyclopiazonic acid & 36 & 13 & Purchase (1971); Nishie et al. (1985) \\
\hline & ß-Nitropropionic acid & 60 & 68 & $\begin{array}{l}\text { Burdock et al. (2001) } \\
\text { Blumenthal et al. (2004) }\end{array}$ \\
\hline & Kojic acid ${ }^{b}$ & 1800 & 5100 & SCCS (2012) \\
\hline
\end{tabular}

${ }^{\mathrm{a}}$ The listed value is for fumonisin B1 as the exact values for B2, B4, and B6 have not been determined

${ }^{\mathrm{b}}$ Kojic acid is not a mycotoxin and is included for comparison purposes only 
Table 6 Secondary metabolites reported from A. niger and closely related species

Secondary metabolite

Small acids: Glyoxylic acid, glycolic acid, hydropyruvic acid, parasorbic acid, sorbic acid, ascorbic acid, fumaric acid, gluconic acid, citric acid, glutaric acid, phenylacetic acid, phenoxyacetic acid,

p-methoxyphenylacetic acid,

4-hydroxymandelic acid, D-galactonic acid Anominine and other aflavinines

Asperamide A \& B

Asperenone

\author{
Aspergetide \\ Aspergillin \\ Aspernigrin A, B, C, D \\ Azanigerones A-F \\ Bicoumanigrin \\ Carlosic acid, agglomerin F, carlosic acid \\ methyl ester \\ Chlovalicin \\ Cycloleucomelon and atromentin \\ Cyclo (trans-4-hydroxy-L-Pro-L-Leu), cyclo \\ (L-Pro-L-Phe), cyclo \\ (trans-4-hydroxy-L-Pro-L-Phe, Cyclo \\ (L-Pro-L-Tyr), cyclo (L.Pro-L-val), cyclo

$$
\text { (L-Pro-L-Leu) }
$$

Funalenone

Gibberellic acid, gibberellin, indoleacetic acid

JBIR-86 and JBIR-87

Malformin A1, A2, B1, B2, B3, B5, C

Kotanin, desmethylkotanin, orlandin

\section{Maltoryzin}

4-Methoxybenzyl-7-phenylacetamido-3-vinyl-3-cephem-4-carboxylate

Nafuredin

Naphtho- $\gamma$-pyrones (asperpyrone A-E, aurasperone $\mathrm{A}-\mathrm{H}, 10,10^{\prime}$-bifonsecin, 6'-O-demethylnigerone,

8'-O-demethylnigerone,

8'-O-demethylisomigerone,

dianhydroaurasperone $\mathrm{C}$,

6,9-dibromoflavasperone, flavasperone,

fonsecin, fonsecine $\mathrm{B}=$ fonsecin

monomethyl ether, fonsecinone A-D,

2-hydroxydihydronigerone, isoaurasperone

$\mathrm{A}, \mathrm{F}$, isonigerone, nigerasperone $\mathrm{A}-\mathrm{C}$,

nigerone, rubasperone $\mathrm{A}-\mathrm{G}$, rubrofusarin,

rubrofusarin $\mathrm{B}=$ heminigerone,

rubrofusarin-6-O- $\alpha$-D-ribofuranoside,
Reference

Comment

Nielsen et al. (2009); Cairns et al. (2018)

Frisvad et al. (2014)

Found in sclerotia of $A$. niger

Zhang et al. (2007a,b,c,d)

Jefferson (1967a,b); Yu et al. (1967);

Pattenden $(1969,1970)$; Rabache et al.

(1974); Rao et al. (2002)

Lee et al. (2015)

Ray and Eakin (1975)

Hiort et al. (2004); Ye et al. (2005); Zhou et al. (2016)

Zabala et al. (2012)

Hiort et al. (2004)

Yang et al. (2014)

Uchoa et al. (2017)

Hiort et al. (2004)

Uchoa et al. (2017)

Produced by A. brasiliensis

Identity of producer not convincingly confirmed

Identity of producer not convincingly confirmed

Inokoshi et al. (1999)

Cihangir (2002); Ates et al. (2006); Lubna et al. (2018)

Takagi et al. (2010); Henrikson et al. (2011)

Curtis and Tanaka (1967); Yoshizawa et al. (1975); Sugawara et al. (1990); Kim et al. (1993); Zhou et al. (2016); Uchoa et al. (2017)

Cutler et al. (1979); Sørensen et al. (2009); Hüttel and Müller (2007); Girol et al.

(2012); Mazzaferro et al. (2015)

Abdelghany et al. (2017)

Bandara et al. (2015)

Ui et al. (2001)

Bouras et al. (2005, 2007); Lu et al. (2014); Choque et al. (2015); Happi et al. (2015); Li et al. (2013); Leutou et al. (2016); Li et al. (2016); Zhou et al. (2016)
Producer is probably A. tubingensis

Identity of producer not convincingly confirmed

Naphtho- $\gamma$-pyrones can be active against antibiotic resistant bacteria, have CNS repressant effects, inhibit Taq DNA polymerase, inhibit xanthine oxidase, inhibit acyl-CoA:cholesterol acyltransferase. Some produced only by $A$. carbonarius or $A$. tubingensis 
Table 6 (continued)

\begin{tabular}{|c|c|c|}
\hline Secondary metabolite & Reference & Comment \\
\hline \multicolumn{3}{|l|}{$\begin{array}{l}\text { (R)-10-(3-succimidyl)-TMC-256A1, } \\
\text { TMC-256A1, B1, C1, C2) }\end{array}$} \\
\hline Nigerasterol A \& B & Liu et al. (2013) & Only produced by $A$. tubingensis \\
\hline Nigerazine A \& B & Iwamoto et al. $(1983,1985)$ & $\begin{array}{l}\text { The producer strain was probably a } \\
\text { A. tubingensis }\end{array}$ \\
\hline Nigerloxin & Rao et al. (2002); Sing et al. (2016) & $\begin{array}{l}\text { Identity of the producer strain is } \\
\text { questionable }\end{array}$ \\
\hline Nigragillin and aspernigerin & $\begin{array}{l}\text { Caesar et al. (1969); Alvi et al. (2000); Shen et } \\
\text { al. (2006); Frisvad et al. (2014); Bandara et } \\
\text { al. (2015) }\end{array}$ & \\
\hline Nygerone A and B & Henrikson et al. (2009) & \\
\hline Penicillin/penicillin-like & Foster and Karow (1945) & Not yet confirmed \\
\hline Pestalamide C & Bandara et al. (2015) & A tensidol \\
\hline "Product B" & Lv et al. (2015) & Structure not known \\
\hline Protocatechuic acid & Lv et al. (2014) & Small acid \\
\hline Pseurotin A \& D & Uchoa et al. (2017) & $\begin{array}{l}\text { Identity of producer not } \\
\text { convincingly confirmed }\end{array}$ \\
\hline Pyranonigrin A-E, S & $\begin{array}{l}\text { Hiort et al. (2004); Schlingmann et al. (2007); } \\
\text { Miyake et al. (2008); Awakawa et al. (2013) }\end{array}$ & \\
\hline Pyrophen & Barnes et al. (1990) & $\begin{array}{l}\text { The producer strain was probably an } \\
\text { A. tubingensis }\end{array}$ \\
\hline Tensidol A and B & Fukuda et al. (2006); Henrikson et al. (2011) & \\
\hline Tensyuic acid A-F & Hasegawa et al. (2007) & \\
\hline Ustiloxin like cyclic ribosomal peptides & Nagano et al. (2016) & \\
\hline $\begin{array}{l}\text { Yanuthones (A-E, 22-deacetylyanuthone, } \\
\text { 1-hydroxyyanuthone A-C) }\end{array}$ & $\begin{array}{l}\text { Bugni et al. (2000); Holm et al. (2014); } \\
\text { Petersen et al. (2015) }\end{array}$ & \\
\hline
\end{tabular}

\section{Aflavinines}

Aflavinines are indoloterpenes biosynthesized from tryptophan and dimethylallyl units. They are only produced in sclerotia of A. niger (Frisvad et al. 2014). Such sclerotia are not produced on ordinary laboratory media, except if they are induced by the presence of small dried fruits, such as raisins (Frisvad et al. 2014). Most aflavinines are antiinsectan, but are not known to be toxic towards vertebrates (Gloer et al. 1988).

\section{Asperamides}

Asperamides are sphingolipids and unusual cerebrosides (Zhang et al. 2007a,b,c,d). Such sphingolipids appear to be pretty widespread in fungi, but their function in fungi is often unknown. The similar flavusides from A. flavus are antibacterial (Yang et al. 2011).

\section{Asperenones}

The terpenes asperenones, asperyellones, and asperrubrols are carotenoid-like secondary metabolites. Asperenone is a human platelet aggregation inhibitor, and a strain of $A$. niger has been optimized for higher production of this bioactive compound (Chidananda et al. 2008).

\section{Aspergitides}

Aspergitides are NRP-derived tetrapeptides which are potentially anti-inflammatory (Lee et al. 2015). These hydrophobic tetrapeptides have some similarity with fungisporins and nidulanins which appear to be generally present in Aspergillus and Penicillium species (Ali et al. 2014; Klitgaard et al. 2015; Hautbergue et al. 2017).

\section{Aspergillin}

Aspergillin is a green polyketide (Ray and Eakin 1975) that may be connected with the production of the black pigment in the spores of $A$. niger. Other (yellow) pigments, such as funalenone and naphtho- $\gamma$-pyrones, are also connected with black melanin (Jørgensen et al. 2011).

\section{Aspernigrins}

The aspernigrins, carbonarones, nygerones, pestalamides, pyrophen, and tensidols are all related 2-benzylpyridin-4- 
one-containing metabolites of non-ribosomal peptide (NRP) and polyketide origin. They have several effects such as inhibiting HIV virus, being antifungal, or having neuroprotective effects (Hiort et al. 2004; Ye et al. 2005; Ding et al. 2008, Bandara et al. 2015; Zhou et al. 2016). They have been isolated from Aspergillus section Nigri isolates and from fungi claimed to be Cladosporium (Ye et al. 2005) and Pestalotiopsis theae (Ding et al. 2008). The latter two fungi appear to have been overgrown by Aspergillus niger and Aspergillus tubingensis, respectively, as all secondary metabolites from these fungi have only been found in Aspergillus section Nigri (Nielsen et al. 2009).

\section{Azanigerones}

The azanigerones A-F needed chromatin remodeling in order to be produced by Aspergillus niger (Zabala et al. 2012). These compounds are polyketides, and little is known of their activity. However, like other azaphilones, they can probably bind amino acids, but no nitrogen-containing derivatives have been found yet.

\section{Cycloleucomelone}

Cycloleucomelone, leucomelone, and atromentin are shikimic acid-derived secondary metabolites that have been found in basidiomycetes (Turner 1971; Turner and Aldridge 1983) but also species in Aspergillus section Nigri (Hiort et al. 2004; Nielsen et al. 2009). These types of compounds may have radiation-protective characteristics, and they are widespread in Aspergillus (Frisvad and Larsen 2015). The analogous (heteroisoextrolites) terphenyllins are for example produced by members of Aspergillus section Candidi and aspulvinones by Aspergillus section Terrei (Turner 1971; Turner and Aldridge 1983; Frisvad and Larsen 2015).

\section{Funalenone and naphtho- $\gamma$-pyrones}

These polyketides have some genes in common with the pksA gene for production of the black pigment in Aspergillus niger (Jørgensen et al. 2011). Some naphtho- $\gamma$-pyrones have been claimed to be toxic (Ghosal et al. 1979), but they are not mycotoxins according to the definition accepted here. In fact, they can be exploited industrially as they have anti-oxidant, anti-cancer, anti-microbial, anti-HIV, anti-hyperuricuric, and anti-tubercular effects (Choque et al. 2015).

\section{Malformins}

Malformins are NRP cyclic peptides that originally were cited as toxic (Anderegg et al. 1976; Kobbe et al. 1977; Cole and Cox 1981), but they are not within the definition of mycotoxins in a strict sense, as malformin $\mathrm{A}$ has an oral $\mathrm{LD}_{50}$ of more than $50 \mathrm{mg} / \mathrm{kg}$ body weight in male mice. The toxicity data of Anderegg et al. (1976) and Kobbe et al. (1977) were based on malformin injection, which is not a natural route of intake. Furthermore, malformins have never been detected after mycotoxicosis caused by $A$. niger. Malformins are very promising anti-cancer agents, however (Park et al. 2017b).

\section{Nafuredin}

Nafuredin is a polyketide terpene-derived secondary metabolite and is an inhibitor of anaerobic electron transport in pig roundworm, but it has very low effect on mammalian enzymes (Ui et al. 2001). It is a promising antihelminthic drug lead candidate.

\section{Nigerasterols}

Nigerasterols are terpene-derived sterols that display potent activity against tumor cell lines (Liu et al. 2013). There are as yet no data on vertebrate toxicity. The fungus (MA-132) was identified only by using ITS sequences, so it may be another species in Aspergillus section Nigri than A. niger that produces nigerasterols.

\section{Nigerazines, aspernigerin, and nigragillins}

The nigerazines, nigragillins, and aspernigerin are all related NRP-derived secondary metabolites. They are weakly insecticidal, and nigerazine B inhibits the root growth of lettuce seedlings (Caesar et al. 1969; Iwamoto et al. 1983). They have not been reported as mycotoxins.

\section{Nigerloxin}

Nigerloxin is derived from an inhibitor of soy bean lipoxygenase and rat lens aldose reductase (Rao et al. 2002a,b). It is a polyketide NRP hybrid. It is a strong antioxidant and is anti-diabetic and of low toxicity (Rao et al. 2005; Suresha and Srinivasan 2013; Vasantha et al. 2018).

\section{Pseurotins}

Pseurotins are NRP polyketide hybrid secondary metabolites that have neuritogenic (Komagata et al. 1996), antibiotic (Mehedi et al. 2010; Pinheiro et al. 2013), anti-inflammatory (Shi et al. 2015), chitin-synthase inhibitor (Wenke et al. 1993), and antileishmanial and anticancer (Martinez-Luis et al. 2012) characteristics. Pseurotin A \& D was reported to be produced together with chlovalicin (Uchoa et al. 2017) probably coded by an intertwined gene clusters, as is the case for Aspergillus fumigatus, where pseurotin A and fumagillin, chemically closely related to chlovalicin, are coded by an intertwined gene cluster (Wiemann et al. 2013; Kishimoto et al. 2017). 
However, psurotins have not been reported from any other isolate of A. niger (Nielsen et al. 2009), so the two metabolites may be produced by another species in Aspergillus section Nigri.

\section{Pyranonigrins}

The pyranonigrins A-K are NRP-PK derived antioxidant secondary metabolites from A. niger (Hiort et al. 2004; Miyake et al. 2007; Kishimoto et al. 2017). There are several pyranonigrins isolated from Aspergillus niger, including pyranonigrin A-K (Kishimoto et al. 2017).

\section{TAN-1612}

The polyketide tetracyclic compound TAN-1612=BMS192548 has been isolates from Aspergillus tubingensis WB 2346 and A. niger ATCC 1015 (Li et al. 2011). It is a neuropeptide Y receptor and neurokinin-1 receptor inhibitor (Kodukula et al. 1995; Shu et al. 1995).

\section{Tensyuic acids}

The tensyuic acids are itaconic acid-derived secondary metabolites with anti-protozoan and antibacterial activities (Hasegawa et al. 2007; Matsumara et al. 2008).

\section{Yanuthones}

The yanuthones are meroterpenoids with a 6-methyl salicylic acid precursor and terpene units attached (Holm et al. 2014; Petersen et al. 2015; Nielsen et al. 2017). There are no toxicity data for yanuthones, but they have antifungal activity (Petersen et al. 2015).

\section{Secondary metabolites described in $A$. oryzae and $A$. flavus}

A. flavus and A. oryzae can produce many secondary metabolites (Table 7). These can be subdivided into biosynthetic families. It is very interesting to note that, e.g., ustiloxin B and ustilaginoidin $\mathrm{C}$, have both been isolated from the rice false smut pathogen Villosiclava virens (= Ustilaginoidea virens) even though they are not biosynthetically related. However, these two types of secondary metabolites have also been found in Aspergillus flavus (Umemura et al. 2014; Tsukui et al. 2015; Yoshimi et al. 2016). This is remarkable as both unrelated fungi occur on rice. One speculation could be that the gene clusters for both ustiloxins and ustilaginoidins were horizontally transferred from one fungus to the other during evolution. Ustilaginoidins are bis-naphtho- $\gamma$-pyrones (even called "mycotoxins" in the paper of Meng et al. 2015 and ustiloxins for toxic cyclic peptides by Tsukui et al. 2015).
Like the heteroisoextrolite (Frisvad and Larsen 2015) analogues in Aspergillus section Nigri (normally also called naphtho- $\gamma$-pyrones, Nielsen et al. 2009; Lu et al. 2014; Choque et al. 2015), the ustilaginoidins are probably also involved in the formation of the green conidium color of Aspergillus section Flavi as it is known for the involvement of naphtho- $\gamma$-pyrones in black pigmentation in Aspergillus section Nigri isolates (Chiang et al. 2011; Jørgensen et al. 2011; Frisvad et al. 2014; Niu et al. 2016). Other important secondary metabolites are described subsequently. Additionally, secondary metabolites that have been erroneously assigned to A. flavus or A. oryzae are also listed (Table 8).

\section{Aflatrems}

Aflatrem and $\beta$-aflatrem and their precursors are indoloterpenes that have been found in sclerotia of Aspergillus flavus (Gallagher and Wilson 1980; Gallagher et al. 1980a,b; Valdes et al. 1985; Tanaka et al. 1989; TePaske et al. 1992; Zhang et al. 2004; Duran et al. 2007; Nicholson et al. 2009; Ehrlich and Mack 2014; Tang et al. 2015; Gilbert et al. 2016). Aspergillus oryzae RIB 40 was found to produce the 13-desoxypaxilline precursor to aflatrem (Rank et al. 2012), and aflatrem has been heterologously expressed in A. oryzae NSAR1 (Tagami et al. 2014). However, if RIB40 is indeed a real A. flavus, A. oryzae sensu stricto isolates are not be able to produce sclerotia and sclerotial metabolites such as aflatrem.

\section{Aflavarins}

Aflavarins are polyketides found in the sclerotia of Aspergillus flavus (TePaske et al. 1992). These polyketides have not yet been found in any A. oryzae strain. Leporins, also found in A. leporis (TePaske et al. 1991), have been found in A. flavus (Cary et al. 2015), but they are not expected to be produced by A. oryzae.

\section{Aflavinins}

The aflavinins are sclerotium-borne indoloterpenes first isolated from A. flavus (Gallagher et al. 1980a,b; Cole et al. 1981; Wicklow and Cole 1982; Gloer et al. 1988). These indoloterpenes and aflavazol were also isolated from the sclerotia of A. oryzae RIB40 (TePaske et al. 1990; Rank et al. 2012). The aflavinins isolated from A. flavus (possibly A. minisclerotigenes or $A$. aflatoxiformans) include aflavinine, dihydroxyaflavinine, monohydroxyaflavinine, and monohydroxyisoaflavinine (Nozawa et al. 1989; Tang et al. 2015).

\section{Asperfuran}

Asperfuran is a dihydrobenzofuran compound that was isolated from Aspergillus oryzae "HA 302-84" (Pfefferle et al. 
Table 7 Primary and secondary metabolites reported from Aspergillus flavus and its domesticated form A. oryzae apart from aflatoxins and CPArelated compounds

\begin{tabular}{|c|c|c|}
\hline Metabolite & Reference & Comment \\
\hline $\begin{array}{l}\text { Antioxidants: } \gamma \text {-tocopherol, d-tocopherol, } \\
\text { genistin, daizein, genistein and } \\
\text { 3-hydroxyanthranilic acid }\end{array}$ & Esaki et al. (1996); Matsuo (1997) & $\begin{array}{l}\text { These are plant metabolites from Glycine } \\
\max \text { (soya) and not produced by the } \\
\text { fungus, however the vitamins } \\
\text { (tocopherols) could also be produced by } \\
\text { A. flavus and A. oryzae }\end{array}$ \\
\hline Asperfuran (= arthrographol) & Pfefferle et al. (1990); Ayer and Nozawa (1990) & \\
\hline Aspergillic acid & $\begin{array}{l}\text { White and Hill (1943); Dutcher (1947); Dunn et } \\
\text { al. (1949); Hummel, 1956; Nakamura 1960; } \\
\text { MacDonald (1961);Assante et al. (1981); } \\
\text { Lebar et al. (2018); Saldan et al. (2018) }\end{array}$ & $\begin{array}{l}\text { Aspergillic acids are strong iron chelators } \\
\text { (Assante et al. 1981), and not produced } \\
\text { by A. oryzae, but by A. flavus }\end{array}$ \\
\hline $\begin{array}{l}\text { Aspergillomarasmin and anhydromarasmic } \\
\text { acid }\end{array}$ & $\begin{array}{l}\text { Plattner and Clauson-Kaas (1945); Hardegger et } \\
\text { al. (1963); Haenni et al. (1962; 1965); Robert } \\
\text { et al. (1962); Lallouette (1962); Lederer } \\
\text { (1962) }\end{array}$ & $\begin{array}{l}\text { The related phytotoxin lycomarasmin is } \\
\text { produced by Fusarium species }\end{array}$ \\
\hline Asperopterin A \& B & Matsuura et al. (1972) & Nucleobase derived \\
\hline $\begin{array}{l}\text { Aspirochlorin = oryzachlorin, } \\
\text { dechloroaspirochlorine and } \\
\text { O,O-dimethylaspirochlorine, } \\
\text { trithioaspirochlorine }\end{array}$ & $\begin{array}{l}\text { Kato et al. (1969); Berg et al. (1976); Sakata et al. } \\
\text { (1982, 1983, 1987,b); Klausmeyer et al. } \\
\text { (2005); Rank et al. (2012); Chankhamjon et al. } \\
\text { (2014) }\end{array}$ & $\begin{array}{l}\text { Original production strains classified as } A \text {. } \\
\text { tamarii, A. oryzae and A. flavus }\end{array}$ \\
\hline Biotin & Fukui et al. $(1955 \mathrm{a}, \mathrm{b})$ & Vitamine \\
\hline Bromoaspirochlorine & Sakata et al. $(1987 a, b)$ & $\begin{array}{l}\text { Aspirochlorin biosynthetic family of } \\
\text { compounds }\end{array}$ \\
\hline Canadensolide & Sakata et al. (1982) & \\
\hline Citric acid & Sakaguchi et al. (1953) & $\begin{array}{l}\text { While A. niger can accumulate large } \\
\text { amounts of citric acid, A. flavus only } \\
\text { produce low amounts }\end{array}$ \\
\hline Drim-9(11)-en-8-ol (R and S) & $\begin{array}{l}\text { Wada et al. (1983); Leite et al. (1986); } \\
\text { Domínguez et al. (1991); Shishido et al. } \\
\text { (1991); Armstrong et al. (1996); Jansen and de } \\
\text { Groot (1991; 2004) }\end{array}$ & \\
\hline $\begin{array}{l}\text { Flufuran, } \\
\text { 5-(hydroxymethyl)-2-furancarboxylic acid, } \\
\text { vanillic acid, 2-furanol, } \\
\text { 2-(4.hydrophenyl)-ethanol, } \\
\text { 3,4-dihydroxybenzoic acid }\end{array}$ & Evidente et al. (2009); Saldan et al. (2018) & \\
\hline Fumaric acid & Sakaguchi et al. (1953) & Small acid \\
\hline l-Glutamic acid & Kinoshita et al. (1961) & Amino acid \\
\hline $\begin{array}{l}\text { Heptelidic acid (= koningic acid), gliocladic } \\
\text { acid, trichoderonic acid, hydroheptelidic } \\
\text { acid }\end{array}$ & $\begin{array}{l}\text { Lee et al. (2016); Skóra et al. (2017); Nishimura } \\
\text { et al. (2018) }\end{array}$ & \\
\hline Inositol & Fukui et al. (1955a,b) & Sugar alcohol \\
\hline$\alpha$-Ketoglutaric acid & Sakaguchi et al. (1953) & Small acid \\
\hline $\begin{array}{l}\text { Kojic acid, methyl kojic acid, dimethyl kojic } \\
\text { acid }\end{array}$ & $\begin{array}{l}\text { Saito (1907); Yabuta (1922); Tamiya (1927); } \\
\text { Birkinshaw et al. (1931); Jennings and } \\
\text { Williams (1945); Parrish et al. (1966); Morton } \\
\text { et al. (1945); Marston (1949); Kistner (1962); } \\
\text { Bentley (2006); Yang et al. (2011) }\end{array}$ & $\begin{array}{l}\text { Production strains classified as A. effusus, } \\
\text { A. luteovirescens or A. lutescens }\end{array}$ \\
\hline Kojic acid-2 (BGY-F) & Zeringue et al. (1999) & Bright green flourescent molecule \\
\hline Kojistatin A = CPI-4, CPI 1-3, CPI 5 & Sato et al. (1996); Yamada et al. (1998) & \\
\hline Lactic acid & Sakaguchi et al. (1953) & Small acid \\
\hline$l$-Malic acid & Sakaguchi et al. (1953); Abe et al. (1961) & Small acid \\
\hline Orange-red pigment & Manonmani and Sreektaniah (1984) & Unknown structure \\
\hline Oryzacidin & Shimoda (1951) & $\mathrm{C}_{8} \mathrm{H}_{13} \mathrm{O}_{5} \mathrm{~N}$, an antibiotic \\
\hline Oryzachlorin $=$ Aspirochlorine $=$ A 30641 & Kato et al. (1969) & See Aspirochlorin \\
\hline Pantothenic acid & Fukui et al. (1955a,b) & Vitamine \\
\hline
\end{tabular}


Table 7 (continued)

\begin{tabular}{|c|c|c|}
\hline Metabolite & Reference & Comment \\
\hline Penicillin & $\begin{array}{l}\text { A. oryzae: Waksman and Bugie (1943); Foster } \\
\text { and Karow (1945); Marui et al. (2010) } \\
\text { A. flavus: White (1940); Bush and Goth (1943); } \\
\text { McKee and MacPhillamy (1943); McKee et } \\
\text { al. (1944); Waksman and Bugie (1943); Bush } \\
\text { et al. (1945); Dey (1945); Adler and } \\
\text { Wintersteiner (1948); Guida (1948) }\end{array}$ & \\
\hline Pyrodoxine & Fukui et al. $(1955 a, b)$ & Vitamine \\
\hline Riboflavin & $\begin{array}{l}\text { Pontovich (1943); Zalesskaya et al. (1950); Mogi } \\
\text { et al. (1952); Higuchi (1956) }\end{array}$ & Vitamine \\
\hline Sporogene AO1 & Tanaka et al. (1984a,b); Tamogami et al. (1996) & \\
\hline Succinic acid & $\begin{array}{l}\text { Srinisavan and Ramakrishnan (1952); Sakaguchi } \\
\text { et al. (1953) }\end{array}$ & Small acid \\
\hline Thiamine & Fukui et al. $(1955 a, b)$ & Vitamine \\
\hline Ustilaginoidin $\mathrm{C}$ & Brown et al. (2003) & Conidium pigment \\
\hline Violacetin & Kobayashi (1966) & $\begin{array}{l}\text { Probably a mistake, most likely originated } \\
\text { from a contaminating Actinomycete }\end{array}$ \\
\hline Vitamine $\mathrm{B}_{12}$ (cyanocobalamine) and $\mathrm{K} 3$ & Sakai (1953); Ramakrishnan and Sathe (1956) & $\begin{array}{l}\text { Vitamine, production strain A. oryzae var. } \\
\text { microsporus }\end{array}$ \\
\hline Ustiloxin B & $\begin{array}{l}\text { Umemura et al. (2013); Nagano et al. (2016); Ye } \\
\text { et al. (2016); Yoshimi et al. (2016) }\end{array}$ & No production in A. oryzae RIB40 \\
\hline
\end{tabular}

1990), but it has also been isolated under the name of arthrographol from Arthrographis pinicola (Ayer and Nozawa 1990) and as asperfuran from Penicillium species (Yamaji et al. 1999; Frisvad et al. 2004, 2006). Asperfuran is antifungal, but there are no reports on toxicity of this compound. Asperfuran production by authentic strains of $A$. oryzae has later been confirmed, and it has also been detected in Aspergillus sojae (Varga et al. 2011b).

\section{Aspergillic acids}

These iron-chelating compounds have been used for discrimination between A. flavus and A. oryzae, in that Aspergillus oryzae sensu stricto has been claimed not to produce any of these pyrazine compounds. Testing Aspergillus flavus sensu stricto and Aspergillus oryzae sensu stricto has shown that it is only the former that can produce aspergillic acids (Bothast and Fennell 1974; Hamsa and Ayres 1977; Pitt et al. 1983; Assante et al. 1981; Liljegren et al. 1988; Varga et al. 2011b). However, compounds in this class have been reported from A. oryzae, including mutaaspergillic acid (Nakamura and Shiro 1959a,b; Nakamura 1961; Sugiyama et al. 1967; Ohta and Ohta 1983), hydroxyaspergillic acid (Nakamura and Shiro 1959a,b; Dutcher 1958 (as A. flavus); MacDonald 1962; Ohta and Ohta 1983; Sano et al. 2007), VI-2 (Ueno et al. 1977), A-2 (Sano et al. 2007), and aspergillic acid (Nishimura et al. 1991). Aspergillic acids have been evaluated for toxicity (Sasaki et al. 1968; MacDonald 1973; Perry et al. 1984), but Sano et al. (2007) suggest that the toxicity of aspergillic acids is so low that it can be present in fermented foods used for consumption. The strains producing aspergillic acid, indicated by the medium AFPA (Aspergillus flavus parasiticus agar), are probably representing Aspergillus flavus sensu stricto, but because of issues with potential aflatoxin production, they are called $A$. oryzae "short stipes." The indicative red-orange color is caused by reaction of ferric ions with aspergillic acids (Assante et al. 1981) with none of these strains have been reported to produce aflatoxins (Sano et al. 2007).

\section{Aspergillomarasmins}

Aspergillomarasmin A, anhydroaspergillomarasmin A, and anhydromarasmic acid are polyamino acid compounds/ phytotoxins related to lycomarasmin from Fusarium (Plattner and Clauson-Kaas 1945; Hardegger et al. 1963), but they have also been found in Aspergillus oryzae or A. flavus (A. "flavus oryzae") (Haenni et al. 1962; Haenni et al. 1965; Robert et al. 1962). Aspergillomarasmin A is very interesting as it inhibits metallo-beta-lactamases and could thus help in overcoming bacterial resistance to penicillin (King et al. 2014; Koteva et al. 2016). There are no data of toxicity of these compounds yet.

\section{Asperopterins}

Asperopterin $\mathrm{A}$ and $\mathrm{B}$ are compounds containing a pteridin ring system that were isolated from Aspergillus oryzae "T-17" (Kaneko and Sanada 1969; Matsuura et al. 1972; Hanaka et al. 
Table 8 Secondary metabolites erroneously ascribed to Aspergillus flavus or A. oryzae

\begin{tabular}{|c|c|c|}
\hline Metabolite & Reference & Comment \\
\hline Aflatoxins in A. oryzae & $\begin{array}{l}\text { El-Hag and Morse (1976) (see Fennell, } \\
\text { 1976); El-Kady et al. (1994); Atalla et } \\
\text { al. (2003) }\end{array}$ & $\begin{array}{l}\text { Aflatoxin production reported from NRRL } 1988 \text { was refuted } \\
\text { by Fennell (1976). The culture was a mixed culture with a } \\
\text { strain of Aspergillus parasiticus. Later reports on aflatoxin } \\
\text { production by A. oryzae were erroneous (Varga et al. 2009) }\end{array}$ \\
\hline Aflatoxin $\mathrm{G} 1$ in A. flavus & Saldan et al. (2018) & $\begin{array}{l}\text { Aflatoxin } \mathrm{G}_{1} \text { has only been found very rarely in A. flavus but } \\
\text { has been found more often in other species in section Flavi } \\
\text { (Frisvad et al. 2019) }\end{array}$ \\
\hline Asperaculin A & Son et al. (2018) & $\begin{array}{l}\text { Identity of strain (KCCM 12698) and compound dubious, } \\
\text { compound only tentatively assigned }\end{array}$ \\
\hline Asperentin $=$ cladosporin, asperentin & Grove (1972a, 1973a) & Producer strain is A. pseudoglaucus (Chen et al. 2017) \\
\hline
\end{tabular}

8-O-methylether, asperentin 6-O-methyl

ether, 5'-hydroasperentin

Asperflavin, anhydroasperflasvin,

5,7-dihydroxy-4-methylphthalide

Asporyzin A, B and C

Austalide F \& H

Aspyrone

Betaine

Chrysogine

Cyclopenol

Deacetoxyscirpenol (DON)

Deacetylparasiticolide A

Decumbenone B

5,7-Dihydroxy-4-methylisobenzofuran-1(3H)-one

Dihydroxymethoxycoumarin \&

ketone-citreoisocoumarin

Emindole SB

Emeniveol

Gliotoxin

\section{Gregatin B}

Hexylitaconic acid

4-hydroxy-asperentin, 5'-hydroxyasperentin 8-methyl ether

Hydroxysydonic acid

Isoflavipucine

JBIR-03

Kipukacin J

Maltoryzin

Mycophenolic acid

Nicotinic acid

Nivalenol, deoxynivalenol, T-2 toxin
El-Hag and Morse (1976) (see Fennell, 1976); El-Kady et al. (1994); Atalla et

Grove (1972b)

Qiao et al. (2010a); Nozawa et al. (1988); Kimura et al. (1992)

Son et al. (2018)

Saldan et al. (2018)

Saldan et al. (2018)

Saldan et al. (2018)

Zhuravleva et al. (2016)

Rahssaparpoor (2014)

Saldan et al. (2018)

Zhuravleva et al. (2016)

Grove (1972a,b); Kobayashi et al. (1990)

Son et al. (2018)

Qiao et al. (2010a); Nozawa et al. (1988); Kimura et al. (1992)

Qiao et al. (2010a); Nozawa et al. (1988); Kimura et al. (1992)

Lewis et al. (2005); Kupfahl et al. (2008)

Saldan et al. (2018)

Son et al. (2018)

Grove (1973b)

Saldan et al. (2018)

Mituzani et al. (2016)

Qiao et al. (2010a); Nozawa et al. (1988); Kimura et al. (1992)

Zhuravleva et al. (2016)

Iizuka and Iida (1962); Bakhali et al. (2013)

Kobayashi et al. (1990)

Saldan et al. (2018)

Elsahrkawy and Abbas, 1991; Atalla et al. (2003)
Producer strain is A. pseudoglaucus (Chen et al. 2017)

Producer strain is A. niveus, A. cejpii or A. striatus

Identity of strain and compound dubious, compounds tentatively assigned

Identity of strain and compound dubious

Identity of strain and compound dubious

Chrysogine has not been found in A. flavus, but in other members of Aspergillus section Flavi (Frisvad et al. 2019)

Producer strain was probably Aspergillus amoenus

Misidentification of compound. Producer strain was claimed to be $A$. flavus

Identity of strain and compound dubious, parasiticolides have not been found in A. flavus, but in other members of Aspergillus section Flavi (Frisvad et al. 2018)

Producer strain is probably Aspergillus amoenus

A. pseudoglaucus is the actual producer of this compound

Identity of strain and compound dubious; compound tentatively assigned

Producer strain is A. niveus, A. cejpii or A. striatus

Producer strain is A. niveus, A. cejpii or A. striatus

Data not substantiated (Patron et al. (2007); Manzanares-Miralles (2016); Vidal-Garcia et al. (2018)

Identity of strain and compound dubious

Identity of strain and compound dubious; compound tentatively assigned by MS

A. pseudoglaucus is the actual producer of this compound

Identity of strain and compound dubious

Producer strain is A. flavipes, not $A$. flavus

Producer strain is A. niveus, A. cejpii or A. striatus

Producer strain is Aspergillus amoenus

Assigned to A. flavus var. microsporis but the producer strain is probably A. clavatus (Varga et al. 2007)

A. pseudoglaucus is the actual producer of this compound (Chen et al. 2017)

Identity of strain and compound dubious

Apparently both fungus and mycotoxin were misidentified in this work, the substrate was contaminated, or the 
Table 8 (continued)

\begin{tabular}{|c|c|c|}
\hline Metabolite & Reference & Comment \\
\hline & & $\begin{array}{l}\text { trichotecenes were biotransformed (also the case for } A \text {. } \\
\text { niger) }\end{array}$ \\
\hline Ochratoxin A and B & Atalla et al. (2003) & $\begin{array}{l}\text { Apparently both fungus and mycotoxin were misidentified in } \\
\text { this work }\end{array}$ \\
\hline Pentahydroxy-anthraquinone & Son et al. (2018) & $\begin{array}{l}\text { Identity of strain and compound dubious; compound } \\
\text { tentatively assigned }\end{array}$ \\
\hline Omoflavipucine & Mituzani et al. (2016) & Producer strain is A. flavipes, not A. flavus \\
\hline Phomaligin A & Saldan et al. (2018) & Identity of strain and compound dubious \\
\hline Spinulosin & Saldan et al. (2018) & Identity of strain and compound dubious \\
\hline Sterigmatocystin in A. oryzae & Atalla et al. (2003) & $\begin{array}{l}\text { Apparently both fungus and mycotoxin were misidentified in } \\
\text { this work }\end{array}$ \\
\hline (3S,6S)-Terramide A and B & Garson et al. (1986) & $\begin{array}{l}\text { Listed as being produced also by } A \text {. flavus, in addition to } A \text {. } \\
\text { terreus in AntiBase, no references could be found to the } \\
\text { possible fact that } A \text {. flavus can produce terramides }\end{array}$ \\
\hline Terrein & Saldan et al. (2018) & Identity of strain and compound dubious \\
\hline Taxol & El-Sayed et al. (2018) & $\begin{array}{l}\text { Both producer and secondary metabolite production needs to } \\
\text { be verified }\end{array}$ \\
\hline Violacetin & Kobayashi (1966); Aiso et al. (1955) & $\begin{array}{l}\text { Violacetin is a Streptomyces secondary metabolite, not of } \\
\text { fungal origin }\end{array}$ \\
\hline Zearalenone & Atalla et al. (2003) & $\begin{array}{l}\text { Apparently both fungus and mycotoxin were misidentified in } \\
\text { this work }\end{array}$ \\
\hline
\end{tabular}

2012) and have since been synthesized (Sugimoto et al. 1986; Hanaka and Yamamoto 2013). Unfortunately, the original producer strain is not available, and there are no toxicity data available for the asperopterins. These compounds are blue fluorescing, so if they are produced by $A$. oryzae sensu stricto, these may be the compounds that could have been erroneously detected and identified as aflatoxins.

\section{Aspirochlorines}

Aspirochlorine is a halogenated diketopiperazine with a central disulfide bridge that was first isolated from Aspergillus oryzae IAM-2613 under the name oryzachlorin (Kato et al. 1969). The compound has also been chemically synthesized (Miknis and Williams 1993; Wu et al. 2000). However, oryzachlorin was later shown to be the same as aspirochlorine and A30641 (Sakata et al. 1982, 1983, 1987a, 1987b). It was isolated under the name A30641 from Aspergillus tamarii NRRL 8101, where it was co-occurring with canadensolide (Berg et al. 1976), as was also the case of a strain identified as A. flavus (Sakata et al. 1982). A strain of the latter was not available for more detailed studies. Another strain identified as A. flavus ("MDH-1420") was shown to produce aspirochlorin and the related compound tetrathioaspirochlorine, and evidence for presence of the trithio analogue also (Klausmeyer et al. 2005). Furthermore, a bromoaspirochlorin, dechloroaspirochlorine, and O,Odimethylaspirochlorine have been reported (Sakata et al. 1987). Aspirochlorin has been shown to be a highly selective and potent inhibitor of protein synthesis (Monti et al. 1999) and an effective inhibitor of fungi, bacteria, viruses, and murine tumor cells (Monti et al. 1999; Chankhamjon et al. 2014). For these reasons and because epipolythiodiketopiperazines are generally toxic, the latter authors called aspirochlorin for a mycotoxin. The related mycotoxin gliotoxin was reported from 4 and 13\% of clinical Aspergillus flavus strains (Lewis et al. 2005; Kupfahl et al. 2008), but there is some doubt whether these data are correct (Patron et al. 2007; Manzanares-Miralles et al. 2016; Vidal-Garcia et al. 2018). On the other hand, Shaaban et al. (2014) isolated the reduced form of gliotoxin from A. "oryzae" MMAO1, and this latter isolate could be Aspergillus flavus sensu stricto. Gliotoxin-producing isolates have not been available for the scientific community (Varga et al. 2011b). Aspirochlorin is a product of many species in section Flavi: $A$. avenaceus, A. caelatus, A. oryzae, A. parvisclerotigenus, $A$. sojae, and A. tamarii (Varga et al. 2011b).

\section{Asporyergosterol}

Asporyergosterol and several other sterols were isolated from isolated from Aspergillus oryzae "cf-2" = CCTCC M 2010045, isolated from a marine alga (Qiao et al. 2010b). The strain isolated could equally well be another Aspergillus, as A. oryzae in principle cannot be isolated from natural sources. An oxylipin and several sterols were isolated from A. flavus, isolated from an alga by the same authors (Qiao et al. 2011). The isolate also produced emeniveol and similar compounds and could probably in reality be A. cejpii, A. niveus, or A. striatus. 


\section{Avenaciolides and canadensolides}

Canadensolides are formed via condensation of an acetate derived chain with a TCA cycle intermediate (Brookes et al. 1963; Turner 1971; Tanabe et al. 1973). It was first isolated from "Penicillium" canadense (McCorkindale et al. 1968), but it has been reported once from A. flavus (Sakata et al. 1982), and the related avenaciolide has been reported from A. avenaceus in Aspergillus section Flavi (Brookes et al. 1963; Tanabem et al. 1973; Varga et al. 2011b). The avenaciolides are also present in Aspergillus glaber and A. stramenius from Aspergillus section Fumigati (Ellis et al. 1964; Samson et al. 2007), and the avenaciolides are active against methicillin-resistant Staphylococci (Chang et al. 2015). Avenaciolide is also a specific inhibitor of glutamate transport in rat liver mitochondria (McGivan and Chappell 1970). Isoavenaciolide has been reported as an anti-cancer agent (Al-Tel et al. 2009). However, there are no indications that avenaciolide is a mycotoxin.

\section{Csypyrones}

Type III polyketides are rare among fungi, but more common in plants and bacteria (Juvvadi et al. 2005; Hashimoto et al. 2014; Shimizu et al. 2017). Aspergillus oryzae can, however, produce csypyrone B1, B2, and B3 and 3,5-dihydroxybenzoic acid (Seshime et al. 2005, 2010a,b; Hashimoto et al. 2013). Interestingly, Aspergillus niger produces protocatechuic acid, also a type III polyketide (Lv et al. 2014). Other fungi that can produce type III polyketides are and Botrytis cinerea (Hashimoto et al. 2014). There are no toxicity data for these secondary metabolites.

\section{Drim-9(11)-en-8-ol (R and S)}

This sesquiterpene compound has been isolated from $A$. oryzae strains that also produce sporogen $\mathrm{AO} 1$ and similar compounds, but very little is known on the bioactivity of this compound (Wada et al. 1983; Leite et al. 1986; Domíngues et al. 1991; Shishido et al. 1991; Armstrong et al. 1996; Jansen and de Groot 1990; 2004).

\section{Flufuran}

Flufuran, other related furans, and small molecular weight secondary metabolites, including 4-hydroxybenzoic acid, were isolated from Aspergillus oryzae and A. flavus (Evidente et al. 2009; Lee et al. 2016; Saldan et al. 2018). Flufuran has antifungal activity (Evidente et al. 2009).

\section{Heptelidic acids}

Heptelidic acid (=koningic acid), hydroheptelidic acid, gliocladic acid, and trichoderonic acid are sesquiterpenes that have antibiotic and anticancer properties (Itoh et al. 1989; Nakazawa et al. 1997; Kim and Lee 2009). Heptelidic acid has been reported from both Aspergillus oryzae and A. flavus (Lee et al. 2016; Skóra et al. 2017).

\section{Kojic acids}

Kojic acid was the first compound to be isolated from Aspergillus oryzae (Yabuta 1912, 1922; Birkinshaw et al. 1931; Jennings and Williams 1945; Parrish et al. 1966; Morton et al. 1945; Marston 1949; Bentley 2006). A dimer of kojic acid has been structure-elucidated as the bright greenish yellow flourescence pigment from Aspergillus flavus (Zeringue et al. 1999). Koji acid is common for nearly all species in Aspergillus section Flavi (Varga et al. 2011b). However, kojic acid is not regarded as a mycotoxin (Bentley 2006). The gene cluster coding for kojic acid production is known (Terabayashi et al. 2010). 7-O-acetylkojic acid has also been isolated from A. flavus (Sun et al. 2014).

\section{Kojistatins}

An isolate of an industrial strain of Aspergillus oryzae (ATCC 20386 and FERM-15834) produced kojistatin A = CPI-4 and related cystein protease inhibitors, called CPI 1-5 (Sato et al. 1996; Yamada et al. 1998). The kojistatins are nonribosomal peptide-polyketide hybride molecules. There are no data on the toxicity of these compounds.

\section{Maltoryzin}

The polyketide maltoryzin was reported from a strain of $A$. oryzae var. "microsporis" isolated from malting barley (Iizuka and Iida 1962). However, the fungus could also be an Aspergillus clavatus, which is very common in malting barley (Lopez Diaz and Flannigan 1997). A. oryzae or A. flavus has not been reported from malting barley. On the other hand, Bakhali et al. (2015) reported on maltoryzin production by A. flavus from walnuts.

\section{Miyakamides}

Miyakamides $A_{1}, A_{2}, B_{1}$, and $B_{2}$ (Shiomi et al. 2002), and oryzamide $A_{1-2}$ (Rank et al. 2012) have been reported from both Aspergillus flavus "var. columnaris" FKI-0739 and A. oryzae RIB40 and are NRPs. The miyakamides are antimicrobial compounds, but there are no toxicity data on these compounds. Since the A. flavus strain FKI-0739 produced hydroxyaspergillic acid also (Shiomi et al. 2002), it was probably an A. flavus sensu stricto. As discussed earlier, RIB40 may also in reality be an A. flavus sensu stricto. 


\section{Oryzaeins}

The polyketides oryzaein A-D, tabaisocoumarin A, caudacoumarin $\mathrm{C}$, versicolol $\mathrm{B}$, and exserolide $\mathrm{D}$ and $\mathrm{F}$ are antiviral and cytotoxic isocoumarin derivatives isolated from a fungus identified as A. oryzae isolated from the rhizome of the marine Paris polyphylla var. yunnanensis (Zhou et al. 2016), and thus, the producing strain is probably an A. flavus sensu stricto. However, compounds with isochroman chromophores have been found in extracts of some A. oryzae (Frisvad JC, "personal data"). The four oryzaeins had moderate to weak inhibitory effect against some human tumor cell lines (Zhou et al. 2016), but their actual toxicity is unknown.

\section{Oryzines}

Oryzines are maleidrides biosynthetically produced from acyl CoA thiolester and from oxaloacetic acid (Wasil et al. 2018). RIB 203, the producing strain, is from sake-koji and thus represents a real A. oryzae. There are no data on the bioactivity of these compounds as yet.

\section{Parasiticolides}

Parasiticolide $\mathrm{A}=$ astellolide $\mathrm{A}$ is a sesquiterpene that was first found in Aspergillus parasiticus from section Flavi (Hamasaki et al. 1975) and Aspergillus stellatus from section Nidulantes (Gould et al. 1981), and later parasiticolide A, dideacetylparasiticolide A, and 14-deacetyl parasiticolide A were isolated from A. oryzae RIB40 (Rank et al. 2012). Ren et al. (2015) found astellolides A, B, C-E, and F-I in Aspergillus oryzae QXPV-4 isolated from the insect Coccinella septempunctata. The origin of QXPV-4 indicates that this was also an A. flavus sensu stricto, rather than an A. flavus. Shinohara et al. (2016) also found parasiticolides $=$ astellolides in A.oryzae RIB40: 14-deacetyl astellolide A = 14-deacetyl parasiticolide A (already found by Rank et al. 2012), and 14-deacetyl astellolide B. Depending on the opinion of the taxonomic status of A. flavus and A. oryzae, parasiticolides are secondary metabolites of one of these species or both.

\section{Penicillins}

Penicillins are non-ribosomally synthesized tripeptides (NRP) that have been reported from A. oryzae (Waksman and Bugie 1943; Foster and Karow 1945; Marui et al. 2010) and A. flavus originally as flavicidin (Bush and Goth 1943; McKee and MacPhillamy 1943; McKee et al. 1944; Waksman and Bugie 1943; RG Benedict, unpublished in Raper 1946). This important antibiotic is not regarded as a mycotoxin, but it is unwanted in industrial fermentations due to its wide use to treat microbial infections.

\section{Pseurotins}

Pseurotins are hybrid NRP/PKS compounds that have been found in A. leporis and A. nomius from Aspergillus section Flavi (Varga et al. 2011b) and were also reported from $A$. "oryzae" MMAO1 (Shaaban et al. 2014) and A. flavus (Rodríguez et al. 2015). The pseurotins are not regarded as mycotoxins, but these compounds should be examined in more detail, as they have neuritogenic (Komagata et al. 1996), antibiotic (Mehedi et al. 2010; Pinheiro et al. 2013), anti-inflammatory (Shi et al. 2015), chitin-synthase inhibitor (Wenke et al. 1993), and antileishmanial and anticancer (Martinez-Luis et al. 2012) characteristics.

\section{Sporogens}

Sporogen AO1 (=13-desoxyphomenone) is a sesquiterpenoid that was isolated from Aspergillus oryzae NOY-2, but the strain is not available to the scientific community. This compound induces conidiation in a less sporulating strain (Tanaka et al. 1984,b). Sporogen AO1 has later been found in strains of $A$. flavus (Frisvad and Larsen, unpublished). Phomenone, related to sporogen AO1, is a potent inhibitor of protein synthesis (Moule et al. 1977) and has moderate toxicity to shrimps (Capasso et al. 1984). Phomenone was recently shown to stimulate pro-inflammatory responses in murine cells and thus may exacerbate allergic reactions if inhaled (Rand et al. 2017). There are no direct data showing that these compounds are mycotoxins, but they are not unlike the mycotoxin PR-toxin in structure (Cole and Cox 1981; Moule et al. 1977; Capasso et al. 1984). Many of the sporogens are phytotoxins (Daengrot et al. 2015).

\section{TMC-2A, $-2 B$ and $-2 C$}

The NRP-derived peptide-like compounds TMC-2A, -2B, and $2 \mathrm{C}$ were isolated from a strain identified as A. oryzae A374 = FERM P-14934 (Nonaka et al. 1997; Asai et al. 1997). From the description of the strain, and as it was isolated from soil, it appears that the strain is rather an Aspergillus tamarii, as the conidia were large, distinctly roughened, and brown. These peptide-like compounds may be used as lead compounds to find better rheumatoid arthritis inhibitors, but toxicity data have not been presented.

\section{Tryptophenalins}

A fungus identified as A. oryzae (MMAO1) was isolated from rice hulls, and this fungus produced a dimeric diketopiperazine compound, ditryptophenaline, 7,9-dihydroxy-3-(1H-indol-3ylmethyl)-8-methoxy-2,3,11,11a-tetrahydro-6H-pyrazino[1,2b]isoquinoline-1,4-dione, cyclo-(Trp-Tyr), cyclo-(Pro-Val), $\alpha$ cyclopiazonic acid, (bismethylthio)gliotoxin, pseurotin A, kojic acid, linoleic acid, and uridine (Shaaban et al. 2014). Since the 
isolate was from rice hulls in a domesticated field, it was probably an A. flavus, but it could also be an A. nomius since pseurotin A has only been found once in A. flavus (see Varga et al. 2011b; Rodríguez et al. 2015). Ditryptoleucine, related to ditryptophenaline from A. flavus (Springer et al. 1977) was isolated from A. oryzae RIB40 (Rank et al. 2012). The toxicity of the diketopiperazines cyclo-(Trp-Tyr), cyclo-(Pro-Val) is unknown. The monomer of ditryptophenaline, cyclo-Nmethylphenyl-alanyltryptophanyl has also been isolated (Kozlovskii et al. 1990).

\section{Ustilaginoidins}

The polyketide ustilaginoidin $\mathrm{C}$ was isolated as a suggested conidium pigment from A. parasiticus (Brown et al. 2003), and a compound with the same chromophore has been isolated from A. flavus (Frisvad, JC, unpublished data), so it could be representing the general naphtho- $\gamma$-pyrone pigment type produced in Aspergillus section Flavi. There are no toxicity data on these compounds.

\section{Ustiloxin B}

This ribosomally produced cyclic peptide (RIPS, ribosomally produced peptides) compound was isolated from Aspergillus flavus and A. oryzae (Umemura et al. 2013, b, 2014; Ye et al. 2016; Yoshimi et al. 2016). The ustiloxins are phytotoxins first isolated from Villosiclava virens (= Ustilaginoidea virens), and they exibit potent antimitotic activity and inhibit microtubule assembly (Koiso et al. 1994), and they have also been called mycotoxins (Koiso et al. 1992). The ustiloxins are not established as mycotoxins. A. oryzae RIB40 does not produce ustiloxin B, probably because of the large deletion of the ustR gene encoding a transcriptional regulation that regulates ustiloxin B production (Umemura et al. 2014).

\section{Secondary metabolites that are not produced by $A$. flavus or A. oryzae}

Due to the close relatedness between A. flavus and A. oryzae as well as their similarity to other species, some reports have misleadingly described production of secondary metabolites in A. flavus or A. oryzae that they do not produce (Table 8).

\section{Secondary metabolites described in $T$. reesei}

Peptaibol non-ribosomal peptides (peptaibiotics) and similar peptides are produced by many Trichoderma species (Zeilinger et al. 2016), but it is only paracelsin A, C, and D in this class that have been reported from T. reesei (Brückner and Graf 1983; Brückner et al. 1984; Pócsfalvi et al. 1997; Przybylski et al. 1984). The paracelsins were reported from an authentic strain of $T$. reesei (QM 9414 (mutant of QM 6a) = ATCC 26421 = CBS 392.92 and the wild ex type strain from cotton duck shelter, Bougainville Island QM 6a (= ATCC 13631=CBS 383.78). Paracelsins are linear peptides containing a high level of uncommon amino acids, alphaaminoisobutyric acid (Aib), and isovaline (Iva), together with an acetylated N-terminal amino acid and a Cterminal amino alcohol (Pócsfalvi et al. 1997). These compounds have shown antimicrobial activity. There are no data on the toxicity of the paracelsins.

The sorbicillin biosynthetic family compounds have been reported from Trichoderma sp. USF 2690 (Abe et al. 2001) (strain not available in any culture collection), and it is only mentioned to be a product of $T$. reese $i$ in the Antibase secondary metabolite database. The Trichodermatides (A-D) are produced by a fungus claimed to be a marine $T$. reesei (Sun et al. 2008; Shigehisa et al. 2015), but the culture is unavailable in culture collections, and may be one of the many other known Trichoderma species. T. reesei may also produce some other non-ribosomal peptides, including intracellular and extracellular siderophores (Zeilinger et al. 2016). Siderophores such as ferricrocin have not been claimed to be toxic. Among the polyketides, the genes for a conidium pigment related to aurofusarin and bikaverin have been reported (Zeilinger et al. 2016). This polyketide compound (not structure elucidated) is probably a precursor for the green pigment (melanin) in the conidia of $T$. reesei, and generally, these conidium pigments have not been claimed to be toxic. T. reesei have PKS gene clusters for production of other polyketides, which are not unlike those for citrinin and fumonisins (Baker et al. 2012), but neither citrinin nor fumonisins have been detected in $T$. reesei. In conclusion, the only secondary metabolites that appear to be naturally produced by $T$. reesei are the paracelsins.

Based on genome sequencing data (Schmoll et al. 2016), several potential toxic secondary metabolites may be produced under special conditions. Such secondary metabolites have not been detected yet in $T$. reesei, however. Genome sequencing showed that there are 8 NRKS, 11 PKS, 2 NRPS-PKS hybrid, and 12 terpenoid synthase encoding genes (Schmoll et al. 2016; Zeilinger et al. 2016). The LaeA and VELVET regulatory genes are important for the expression of secondary metabolites in $T$. reesei, but nevertheless, only few of the putative gene clusters for secondary metabolites seem to be actually expressed.

\section{Conclusions}

Aspergillus oryzae produce few recognized mycotoxins, and they are only produced by few strains. If they are produced, there are genetic means of inactivating the biosynthetic pathways, so isolates of the species can be exploited for production of enzymes and as a transformation host for industrially relevant secondary metabolites or enzymes. Some isolates of Aspergillus niger can produce three types of mycotoxins, ochratoxin $A$, fumonisin $B_{2}\left(B_{4}\right.$ and $\left.B_{6}\right)$, and oxalic acid. Again, 
genetic means have been employed to inactivate the gene clusters for ochratoxins and fumonisins, while accumulation of the less toxic oxalic acid can be avoided by chosing an optimal substrate or use optimal procedures for the industrial products. Trichoderma reesei cannot produce any recognized mycotoxins and is one of the most important enzyme producers in the industry. All three species can produce interesting secondary metabolites, of which some are drug lead candidates and others, such as citric acid, are important bulk chemicals that are produced by fermentation.

\section{Compliance with ethical standards}

Conflict of interest The authors declare that they have no conflict of interest.

Ethical approval This article does not contain any studies with human participants or animals performed by any of the authors.

Open Access This article is distributed under the terms of the Creative Commons Attribution 4.0 International License (http:// creativecommons.org/licenses/by/4.0/), which permits unrestricted use, distribution, and reproduction in any medium, provided you give appropriate credit to the original author(s) and the source, provide a link to the Creative Commons license, and indicate if changes were made.

\section{References}

Abarca ML, Bragulat MR, Castella G, Cabanes FJ (1994) Ochratoxin A production by strains of Aspergillus niger var. niger. Appl Environ Microbiol 60:2650-2652

Abdelghany TM, El-Nagger MA, Ganash MA, Al Abboud MA (2017) PCR identification of Aspergillus niger with using natural additives for controlling and detection of malformins and maltoryzine production by HPLC. BioNanoSci 7:588-596

Abe K, Gomi K, Hasegawa F, Machida M (2006) Impact of Aspergillus oryzae genomics on industrial production of metabolites. Mycopathologia 162:143-153

Abe S, Saito T, Takayama KI, Furuya A (1961) L-Malic acid by fermentation. British patent no. 884,029, December 6

Abe N, Sugimoto O, Arakawa T, Tanji K, Hirota A (2001) Sorbicillinol, a key intermediate of bisorbicillinoid biosynthesis in Trichoderma sp. USF-2690. Biosci Biotechnol Biochem 65:2271-2279

Adler M, Wintersteiner O (1948) A reinvestigation of flavacidin, the penicillin produced by Aspergillus flavus. J Biol Chem 176:873-891

Aiso K, Arai T, Shidara I, Kurihara H, Morita Y (1955) A new broad spectrum antibiotic, violacetin. J Antibiot 8:33-38

Ali H, Ries MI, Lankhorst PP, van der Hoeven RAM, Schouten OL, Noga M, Hankemeier T, van Peij RAL, Vreeken RJ, Driessen AJM (2014) A non-canonical NRPS is involved in the synthesis of fungisporin and related hydrophobic cyclic tetrapeptides in Penicillium chrysogenum. PLoS ONE 9:e98212

Almassi F, Ghisalberti EL, Rowland CY (1994) Alkylcitrate-derived metabolites from Aspergillus niger. J Nat Prod 57:833-836

Al-Musallam A (1980) Revision of the black Aspergillus species. Centraalbureau voor Schimmelcultures, Baarn

Al-Tel TH, Al-Qawasmeyh R, Sabri SS, Voelter W (2009) Differential use of anhydropyranosides for eantiomere routes to bis-gbutyrolactones: a new approach to the frameworks of antibiotic and anticancer agents isoavenaciolide and ethisolide. $\mathrm{J}$ Org Chem 74:4690-4696

Anderegg RJ, Biemann K, Büchi G, Cusman M (1976) Malformin C, a new metabolite of Aspergillus niger. J Am Chem Soc 98:3365-3370

Andersen MR, Salazar MP, Schaap PJ, van de Vondervoort PJI, Culley D, Thykaer J, Frisvad JC, Nielsen KF, Albang R, Albermann K, Berka RM, Braus GH, Braus-Stromeyer SA, Corrochano LM, Dai Z, van Dijck PWM, Hofmann G, Lasure LL, Magnusson JK, Meijer SL, Nielsen JB, Nielsen ML, van Ooyen AJJ, Panther KS, Pel HJ, Poulsen L, Samson RA, Stam H, Tsang A, van den Brink JM, Atkins A, Aerts A, Shapiro H, Pangilinan J, Salamov A, Lou Y, Lindquist E, Lucas S, Grimwood J, Grigoriev IV, Kubicek CP, Martinez D, van Peij NNME, Roubos JA, Nielsen J, Baker S (2011) Comparative genomics of citric-acid producing Aspergillus niger ATCC 1015 versus enzyme-producing CBS 513.88. Genome Res 21:885-897

Armstrong V, Cortes M, Lopez J (1996) A revision of the absolute configuration of drim-9(11)-en-8-alfa-ol. Nat Prod Lett 8:225-229

Asai Y, Nonaka N, Nishio M, Okamura K, Date T, Sugita T, Ohnuki T, Komatsubara S (1997) TMC-2A, -2B and -2C, new dipeptidyl peptidase IV inhibitors produced by Aspergillus oryzae A374. II. Isolation and structure elucidation. J Antibiot 50:653-658

Asao T, Büchi G, Abdel-Kader MM, Chang SB, Wick EL, Wogan GN (1963) Aflatoxins B and G. J Am Chem Soc 85:1706-1707

Asao T, Büchi G, Abdel-Kader MM, Chang SB, Wick EL, Wogan GN (1965) The structures of aflatoxins B and $\mathrm{G}_{1}$. J Am Chem Soc 87: 882-886

Assante G, Camarda L, Locci R, Merlini L, Nasini G, Papadopoulos E (1981) Isolation and structure of red pigments from Aspergillus flavus and related species, growth on a differential medium. J Agric Food Chem 29:785-787

Atalla MM, Hassanein NM, El-Beih AA, Youssef YAG (2003) Mycotoxin production in wheat grains by different Aspergilli in relation to different relative humidities and storage periods. Nahrung 47:6-10

Ates S, Gökdere M (2006) Effect of silicone oil on gibberellic acid production by Gibberella fujikuroi and Aspergillus niger. Appl Biochem Microbiol 42:500-501

Avalos J, Limon MC (2015) Biological roles of fungal carotenoids. Curr Genet 61:309-324

Awakawa T, Yang X-L, Wakimoto T, Abe I (2013) Pyranonigrin E: a PKS-NRPS hybrid metabolite from Aspergillus niger identified by genome mining. ChemBioChem 14:2095-2099

Ayer WA, Nozawa K (1990) Taxonomy and chemistry of a new fungus from bark beetle infested Pinus contorta var. latifolia. 2. Arthrographol, the metabolite inhibitory to Ophiostoma clavigerum. Can J Microbiol 36:83-85

Baker SE (2006) Aspergillus niger genomics: past, present and into the future. Med Mycol 44:S17-S21

Baker SE, Perrone G, Richardson NM, Gallo A, Kubicek CP (2012) Phylogenomic analysis of polyketide synthase encoding genes in Trichoderma. Microbiology-SGM 158:147-154

Bakhali A, El-Samawaty AMA, Abd El-Rahim MA, Yassin MA, ElNaggar MA, Muhammed MH (2015) Toxigenic fungal biota associated with walnut in Saudi Arabia. J Pure Appl Microbiol 7:10791086

Baltz RH, Demain AL, Davies JE (eds) (2010) Manual of industrial microbiology and biotechnology. 3rd ed, ASM Press, Washington DC

Bandara HMSKH, Kumar NS, Jayasinghe L, Masubuti H, Fujimoto Y (2015) A 3-vinyl cephem derivative, a useful intermediate in the synthesis of cepham antibiotics, from Aspergillus awamori associated with banana fruit. Nat Prod Commun 10:1663-1666

Barbesgaard P, Heldt-Hansen HP, Diderichsen B (1992) On the safety of Aspergillus oryzae: a review. Appl Microbiol Biotechnol 36:569572 
Barnes CL, Steiner JR, Torres E, Pacheco R, Marquez H (1990) Structure and absolute configuration of pyrophen, a novel pyrone derivative of L-phenylalanine from Aspergillus niger. Int J Pept Prot Res 36:292296

Bennett JW, Inamdar AA (2015) Are some fungal volatile organic compounds (VOCs) mycotoxins? Toxins 7:3785-3804

Bentley R (2006) From miso, sake and shoyu to cosmetics: a century of science for kojic acid. Nat Prod Rep 23:1046-1062

Berg DH, Massing RP, Hoehn MM, Boeck LD, Hamill RL (1976) A30641, a new epidithiodiketopiperazine with antifungal activity. J Antibiot 29:394-397

Bertrand RL, Abdel-Hameed M, Sorensen JL (2018) Lichen biosynthetic gene clusters part II: homology mapping suggests a functional diversity. J Nat Prod 81:732-748

Bills GF, Yue Q, Chen L, Li Y, An ZQ, Frisvad JC (2016) Aspergillus mulundensis sp. nov., a new species for the fungus producing the antifungal echinocandin lipopeptides, mulundocandins. J Antibiot 69:141-148

Birkinshaw JH, Charles JHV, Lilly CH, Raistrick H (1931) The biochemistry of microorganisms VII. Kojic acid (5-hydroxy-2hydroxymethylpyrone). Phil Trans R Soc London B220:127-138

Blin K, Wolf T, Chevrette MG, Lu X, Schwalen CJ, Kautsar SA, Duran HGS, de los Santos ELC, Kim HU, Nave M, Dickschat JS, Mitchell DA, Shelest E, Breitling R, Takano E, Lee SY, Weber T, Medema MH (2017) AntiSMASH 4.0 - improvements in chemistry prediction and gene cluster boundary identification. Nucl Acids Res 45: W36

Blochwitz A (1929) Die Gattung Aspergillus. Neue spezies. Diagnosen. Synonyme. Ann Mycol 27:205-240

Blumenthal CZ (2004) Production of toxic metabolites in Aspergillus niger, Aspergillus oryzae and Trichoderma reesei: justification of mycotoxin testing in food grade enzymes derived from the three fungi. Reg Toxicol Pharmacol 39:214-228

Bothast RJ, Fennell DI (1974) A medium for rapid identification and enumeration of Aspergillus flavus and related organisms. Mycologia 66:365-369

Bouras N, Mathieu F, Coppel Y, Lebrihi A (2005) Aurasperone F-a new member of the naphtho-gamma-pyrone class isolated from a cultures microfungus, Aspergillus niger C-433. Nat Prod Res 19:653659

Bouras N, Mathieu F, Coppel Y, Strelkov SE, Lebrihi A (2007) Occurrence of naphtho-gamma-pyrones- and ochratoxin Aproducing fungi in French grapes and characterization of new naphtho-gamma-pyrone polyketide (aurasperone $\mathrm{G}$ ) isolated from Aspergillus niger C-433. J Agric Food Chem 55:8920-8927

Braun MS, Wink M (2018) Exposure, occurrence, and chemistry of fumonisins and their cryptic derivatives. Compr Rev Food Sci Food Saf 17:769-791

Brookes D, Tidd BK, Turner WB (1963) Avenaciolide, an antifungal lactone from Aspergillus avenaceus. J Chem Soc 1963:5385-5391

Brown DW, Hauser FM, Tommasi R, Corlett SS, Salso JJ (2003) Structural elucidation of a putative conidial pigment from Aspergillus parasiticus. Tetrahedron Lett 44:419-422

Brückner H, Graf H (1983) Paracelsin, a peptide antibiotic containing $\alpha$ aminobutyric acid, isolated from Trichodeerma reesei Simmons. Part A. Experientia 39:528-530

Brückner H, Graf H, Bokel M (1984) Paracelsin; characterization by NMR spectroscopy and circular dichroism, and hemolytic properties of a peptaibol antibiotic from the cellulolytically active mold Trichoderma reesei. Part B. Experientia 40:1189-1197

Bugni TS, Abbanat D, Bernan VS, Maiese WM, Gereenstein M, van Wagoner RM, Ireland CM (2000) Yanuthones: novel metabolites from a marine isolate of Aspergillus niger. J Org Chem 65:71957200
Burdock GA, Carabin IG, Madhusudan GS (2001) Safety assessment of $\beta$-nitropropionic acid: a monograph in support of an acceptable daily intake in humans. Food Chem 75:1-27

Burkhardt HJ, Forgacs J (1968) O-methylsterigmatocystin, a new metabolite from Aspergillus flavus, Link ex Fries. Tetrahedron 24:717720

Bush MT, Goth A (1943) Flavicin: an antibacterial substance produced by an Aspergillus flavus. J Pharmacol Exptl Therap 78:164-169

Bush MT, Goth A, Dickison HL (1945) Flavicin II: an antibacterial substance produced by an Aspergillus flavus. J Pharmacol Exp Ther 84: 262-277

Bush MT, Touster O, Brockman JE (1951) The production of $\beta$ nitropropionic acid by a strain of Aspergillus flavus. J Biol Chem 188:685-693

Caesar F, Jansson K, Mutschler E (1969) Über Nigragillin, ein neues Alkaloid aus der Aspergillus niger-Gruppe. 1. Mitteilung. Isolierung and Strukturaufklärung des Nigragillins und eines Dioxopiparazine. Pharm Acta Helv 44:676-690

Cairns TC, Nai C, Meyer V (2018) How a fungus shapes biotechnology: 100 years of Aspergillus niger research. Fung Biol Biotechnol 5:13

Capasso R, Iacobellis NS, Bottalico A, Randazzo G (1984) Structuretoxicity relationships of the eremophilane phomenone and PR-toxin. Phytochemistry 23:2781-2784

Cary JW, Ehrlich KC (2006) Aflatoxigenicity in Aspergillus: molecular genetics, phylogenetic relationship and evolutionary implications. Mycopathologia 162:167-177

Cary JW, Uka V, Han Z, Buyst D, Harris-Coward PY, Ehrlich KC, Wei Q, Bhatnagar D, Down PF, Martens SL, Calvo AM, Martins JC, Vanheaecke L, Coenye T, de Saeger S, di Mavungu JD (2015) An Aspergillus flavus secondary metabolic gene cluster containing a hybrid PKS-NRPS is necessary for synthesis of the 2-pyridones, leporins. Fung Genet Biol 81:88-97

Casadevall A, Pirofski L-A (2003) The damage-response framework of microbial pathogenesis. Nat Rev Microbiol 1:17-24

Cendoya E, Chiotta ML, Zachetti V, Chulze SN, Ramirez ML (2018) Fumonisins and fumonisin producing Fusarium occurrence in wheat and wheat by products: a review. J Cer Sci 80:158-266

Chang C.M, Chern J, Chen M-Y, Huang K-F, Chen CH, Yang YL, Wu SH (2015) Avenaciolides: potenatial Mur A-targeted inhibitors against peptidoglycan biosynthesis in methicillin-resistant Staphylococcus aureus (MRSA). J Am Chem Soc 137:267-275

Chang P-K, Wilkinson JR, Horn BW, Uy J, Bhatnagar D, Cleveland TE (2007) Genes differentially expressed by Aspergillus flavus strains after loss of aflatoxin production by serial transfers. Appl Microbiol Biotechnol 77:917-925

Chankhamjon P, Hoettger-Schmidt D, Scherlach K, Urbansky B, Lackner G, Kalb D, Dahse H-M, Hoffmeister D, Hertweck C (2014) Biosynthesis of the halogenated mycotoxin aspirochlorin in koji mold involves a cryptic amino acid conversion. Angew Chem Int Ed 53:13409-13413

Chen AJ, Hubka V, Frisvad JC, Visagie CM, Houbraken J, Meijer M, Varga J, Rasine D, Jurjević Ž, Kubátová A, Sklenář F, Samson RA (2017) Polyphasic taxonomy of Aspergillus section Aspergillus (formerly Eurotium) and its occurrence in indoor environment and food. Stud Mycol 88:37-135

Chiang Y-M, Meyer KM, Praseuth M, Baker SE, Bruno KS, Wang CCC (2011) Characterization of a polyketide synthase in Aspergillus niger whose product is a precursor for both dihydroxynaphthalene (DHN) melanin and naphtho- $\gamma$-pyrone. Fungal Genet Biol 48:430 437

Chidananda C, Kumar CM, Sattur AP (2008) Strain improvement of Aspergillus niger for the enhanced production of asperenone. Ind $\mathrm{J}$ Microbiol 48:274-278

Choque E, El Rayess Y, Reaynal J, Mathieu F (2015) Fungal naphtho- $\gamma$ pyrones - secondary metabolites of industrial interest. Appl Microbiol Biotechnol 99:1081-1096 
Christensen M (1981) A synoptic key and evaluation of the species in the Aspergillus flavus group. Mycologia 73:1056-1084

Christensen BE, Mølgaard H, Kaasgaard S, Lehmbeck J, Mølgaard MDLH (2000) Producing a polypeptide of interest such as a hormone or enzyme, comprising cultivating a mutant of a parent Aspergillus cell which produces less of at least one toxin of interest compared to the parent cell under the same conditions. Patent, WO200039322, July 6.

Cihangir N (2002) Stimulation of the gibberellic acid synthesis by Aspergillus niger in submerged culture using a precursor. World $\mathrm{J}$ Microbiol Biotechnol 18:727-729

Clevenger KD, Bok JW, Ye R, Miley GP, Verdan MH, Velk T, Chen C, Yang KH, Robey MT, Gao P, Lamprecht M, Thomas PM, Islam MN, Palmer JM, Wu CC, Keller NP (2017) A scalable platform to identify fungal secondary metabolites and the gene clusters. Nat Chem Biol 13:895-901

Cole RJ, Cox RH (1981) Handbook of toxic fungal metabolites. Academic Press, London

Cole RJ, Dorner JW, Springer JP, Cox RH (1981) Indole metabolites from a strain of Aspergillus flavus. J Agric Food Chem 29:293-295

Cole RJ, Kirksey JW, Schroeder HW (1970) Dihydro-Omethylsterigmatocystin, a new metabolite from Aspergilus flavus. Tetrahedron Lett 11:3109-3112

Costa CP, Silva DG, Rudnitskaya A, Almeida A, Rocha SM (2016) Shedding light on Aspergillus niger exometabolome. Sci Rep 6: 27441

Curtis RW, Tanaka H (1967) Production of malformin by Aspergillus awamori. Appl Microbiol 15:1519-1520

Cutler HG, Crumley FG, Cox RH, Hernandez O, Cole RJ, Dorner JW (1979) Orlandin: a nontoxic fungal metabolite with plant growth inhabiting properties. J Agric Food Chem 27:592-595

Daengrot C, Rukachairisikul V, Tansakul C, Thongpanchang T, Phongpaichit S, Bowornwiriyapan K, Sakayaroj J (2015) Eremophilane sesquiterpenes and diphenyl thioethers from the soil fungus Penicillium copticola PSU-RSPG138. J Nat Prod 78:615622

Dey NC (1945) A preliminary note on the antibacterial substance from Aspergillus flavus. Curr Sci (India) 14:265-267

Dickens F, Jones HEH (1961) Carcinogenic activity of a series of reactive lactones and related substances. Br J Cancer 15:85-100

Ding G, Jiang L, Guo L, Chen X, Zhang H, Che Y (2008) Pestalazines and pestalamides, bioactive metabolites from the plant pathogenic fungus Pestalotiopsis theae. J Nat Prod 71:1861-1865

Domíngues G, Hueso-Rodríguez JA, de la Torre MC, Rodríguez B (1991) Synthesis and absolute configuration of drim-9(11)-en-8 ols from Aspergillus oryzae. Tetrahedron Lett 32:4765-4768

Domsch KH, Gams W, Anderson T-H (2007) Compendium of soil fungi. IHW-Verlag, Eching

Dunn G, Newbold GT, Spring FS (1949) Synthesis of flavacol, a metabolic product of Aspergillus flavus. J Chem Soc 1949:2586-2587

Duran RM, Cary JW, Calvo AM (2007) Production of cyclopiazonic acid, aflatrem, and aflatoxin by Aspergillus flavus is regulated by $v e A$, a gene necessary for sclerotial formation. Appl Microbiol Biotechnol 73:1158-1168

Dutcher JD (1947) Aspergillic acid: an antibiotic substance produced by Aspergillus flavus. I. General properties, formastion of desoxyaspergillic acid and structural conclusions. J Biol Chem 171:321-339

Dutcher JD (1958) Aspergillic acid: an antibiotic substance produced by Aspergillus flavus. III. The structure of hydroxyaspergillic acid. J Biol Chem 232:785-796

Dutton MF, Heathcote JG (1968) Structure biochemical properties and origin of aflatoxins $\mathrm{B}_{2 \mathrm{a}}$ and $\mathrm{G}_{2 \mathrm{a}}$. Chem Ind 1968:418-420

Ehrlich KC, Mack BM (2014) Comparison of expression of secondary metabolite biosynthesis cluster genes in Aspergillus flavus, A. parasiticus, and A. oryzae. Toxins 6:1916-1928
El-Hag N, Morse RE (1976) Aflatoxin production by a variant of Aspergillus oryzae (NRRL strain 1988) on cowpeas (Vigna sinensis). Science 192:1345-1346

El-Kady I, El-Maraghy S, Zohri A (1994) Mycotoxin producing potential of some isolates of Aspergillus flavus and Eurotium groups from meat-products. Microbiol Res 149:297-307

Ellis JJ, Stodola FH, Vesonder RF, Glass CA (1964) $\mathrm{A} \mathrm{C}_{15} \mathrm{H}_{22} \mathrm{O}_{4}$ compound produced by the fungus Aspergillus fischeri var. glaber. Nature 203:1382

Elsahrkawy SH, Abbas HK (1991) Metabolism of T-2 toxin by Mucor and Aspergillus sp. Acta Pharm Jugos 41:191-201

El-Sayed ASA, Safan S, Mohamed NZ, Shaban L, Ali GS, Sitohy MZ (2018) Induction of taxol biosynthesis by Aspergillus terreus, endophyte of Podocarpus gracilior Pilger, upon intimate interaction with the plant endogenous microbes. Proc Biochem in press. doi:https:// doi.org/10.1016/j.procbio.2018.04.020

Enomoto M, Saito M (1972) Carcinogens produced by fungi. Annu Rev Microbiol 26:279-312

Esaki H, Onozaki H, Kawakishi S, Ozawa T (1996) New antioxidant isolated from tempeh. J Agric Food Chem 44:696-700

Evidente A, Cristinzio G, Punzo B, Andolfi A, Testa A, Melck D (2009) Flufuran, an antifungal 3,5-disubstituted furan produced by Aspergillus flavus Link. Chem Biodiver 6:328334

Faustinelli PC, Wang XM, Palencia ER, Arias RS (2016) Genome sequences of eight Aspergillus flavus spp., and one A. parasiticus sp., isolated from peanut seeds in Georgia. Genome Announc 4:e00278$\mathrm{e} 00216$

Fennell DI (1976) Aspergillus oryzae (NRRL strain 1988): a clarification. Science 194:1188

Fernagut PO, Diguet E, Stefanova N, Biran M, Wenning GK, Canioni P, Bioulac B, Tison F (2002) Subacute systemic 3-nitropropionic acid intoxication induced a distinct motor disorder in adult C57B1/6 mice: behavioural and histopathological characterization. Neuroscience 114:1005-1017

Foster JW, Karow EO (1945) Microbiological aspects of penicillin. VIII. Penicillin from different fungi. J Bacteriol 49:19-29

Frisvad JC (1989) The connection between the penicillia and aspergilli and mycotoxins with special emphasis on misidentified isolates. Arch Environ Contam Toxicol 18:452-467

Frisvad JC (2011) Rational for a polyphasic approach in the identification of mycotoxigenic fungi. In: De Saeger S (ed) Determining mycotocins and mycotoxigenic fungi in food and feed. Woodhead Publishing, Sawston, pp 279-297

Frisvad JC, Hubka V, Ezekiel CN, Hong S-B, Nováková A, Chen AL, Arzanlou M, Larsen TO, Sklenár F, Mahakarnchanakul W, Samson RA, Houbraken J (2019) Taxonomy of Aspergillus section Flavi and their production of aflatoxins, ochratoxins and other mycotoxins. Stud Mycol 93:1-63

Frisvad JC, Larsen TO (2015) Chemodiversity in the genus Aspergillus. Appl Microbiol Biotechnol 99:7859-7877

Frisvad JC, Larsen TO, Dalsgaard PW, Seifert KA, Louis-Seize G, Lyhne EK, Jarvis BB, Fettinger JC, Overy DP (2006) Four psychrotolerant species with high chemical diversity consistently producing cycloaspeptide A, $P$. jamesonlandense sp. nov., $P$. ribium sp. nov., P. soppii and P. lanosum. Int J Syst Evol Microbiol 56:1427-1437

Frisvad JC, Larsen TO, Thrane U, Meijer M, Varga J, Samson RA, Nielsen KF (2011) Fumonisin and ochratoxin production in industrial Aspergillus niger strains. PLoS ONE 6:e23496

Frisvad JC, Petersen LM, Lyhne EK, Larsen TO (2014) Formation of sclerotia and production of indoloterpenes by Aspergillus niger and other species in section Nigri. PLoS ONE 9:e94857

Frisvad JC, Smedsgaard J, Larsen TO, Samson RA (2004) Mycotoxins, drugs and other extrolites produced by species in Penicillium subgenus Penicillium. Stud Mycol 49:201-241 
Frisvad JC, Smedsgaard J, Samson RA, Larsen TO, Thrane U (2007) Fumonisin $\mathrm{B}_{2}$ production by Aspergillus niger. J Agric Food Chem 55:9727-9732

Fu Y, He F, Zhang S, Jiao X (1995) Consistent striatal damage in rats induced by 3-nitropropionic acid and cultures of Arthrinium fungus. Neurotoxicol Teratol 17:413-418

Fujii R, Ugai T, Ichonose H, Hatakeyama M, Kosaki T, Gomio K, Fujii I, Minami A, Oikawa H (2016) Reconstitution of biosynthetic intermediates by expression host. Biosci Biotechnol Biochem 80:426431

Fujimoto Y, Miyagawa H, Tsurushima T, Irie H, Okamura K, Ueno T (1993) Structures of antafumicins A and B, novel antifungal substances produced by the fungus Aspergillus niger NH-401. Biosci Biotechol Biochem 57:1222-1224

Fukuda T, Hasegawa Y, Hagimori K, Yamaguchi Y, Masuma R, Tomoda H, Omura S (2006) Tensidols, new potentiators of antifungal miconazol activity, produced by Aspergillus niger FKI-2342. J Antibiot 59:480-485

Fukui S, Tani Y, Kishibe T (1955a) The role of B vitamins in sake brewing, II, The nature of a growth-stimulating factor produced by Aspergillus oryzae for Saccharomyces sake and its relationship to pantothenic acid. J Ferment Technol 33:59-64

Fukui S, Tani Y, Kishibe T (1955b) The role of B vitamins in sake brewing, IV. Biosynthesis and decompositions of B vitamins by Saccharomyces sake and Aspergillus oryzae. J Ferment Technol 33:175-179

Galagan JE, Calvo SE, Cuomo C, Ma L-J, Wortman JR, Batzoglou S, Lee S-I, Bastürkmen M, Spevak CC, Clutterbuck J, Kapitonov V, Jurka J, Scazzocchio C, Farman M, Butler J, Purcell S, Harris S, Braus GH, Draht O, Busch S, D’Enfert C, Bouchier C, Goldman GH, BellPedersen D, Griffith-Jones S, Doonan JH, Yu J, Vienken K, Pain A, Freitag M, Selker EU, Archer DB, Penalva MA, Oakley BR, Momany M, Tanaka T, Kumagai T, Asai K, Machida M, Nierman WC, Denning DW, Caddick M, Hynes M, Paoletti NM, Fischer R, Miller B, Dyer P, Sachs MS, Osmani SA, Birren BW (2005) Sequencing of Aspergillus nidulans and comparative analysis with A. fumigatus and A. oryzae. Nature 438:1105-1115

Gallagher RT, Clardy J, Wilson BJ (1980a) Aflatrem, a tremorgenic toxin from Aspergillus flavus. Tetrahedron Lett 21:239-242

Gallagher RT, McCabe T, Hirotsu K, Clardy J, Nicholson J, Wilson BJ (1980b) Aflavinine, a novel indole-mevanolate metabolite from tremorgen-producing Aspergillus flavus species. Tetrahedron Lett 21:243-246

Gallagher RT, Richard JL, Stahr HM, Cole RJ (1978) Cyclopiazonic acid production by aflatoxigenic and non-aflatoxigenic strains of Aspergillus flavus. Mycopathologia 66:31-36

Gallagher RT, Wilson BJ (1980) Aflatrem, the tremorgenic mycotoxin from Aspergillus flavus. Mycopathologia 66:183-185

Gallo A, Ferrara M, Perrone G (2017) Recent advances on the molecular aspects of ochratoxin A biosynthesis. Curr Op Food Sci 17:49-56

Gardner SN, Slezak T, Hall BG (2015) kSNP3.0: SNP detection and phylogenetic analysis of genomes without genome alignment or reference genome. Bioinformatics 31:2877-2878

Garson MJ, Jenkins SM, Staunton J, Chaloner PA (1986) Isolation of some new 3,6-dialkyl-1,4-dihydroxypiperazine-2,5-diones from Aspergillus terreus. J Chem Soc Perkin Trans I 1986:901-903

Geiser DM, Dorner JW, Horn BW, Taylor JW (2000) The phylogenetics of mycotoxin and sclerotium production in Aspergillus flavus and Aspergillus oryzae. Fungal Genet Biol 31:169-179

Geiser DM, Pitt JI, Taylor JW (1998) Cryptic speciation and recombination in the aflatoxin-producing fungus Aspergillus flavus. Proc Nat Acad Sci USA 95:388-393

Georgianna D, Fedorova ND, Yu J, Machida M, Rokas A, Baker S, Dean R, Brown D, Dolexal A, Bhatnagar D, Cleveland T, Wortman J, Maiti R, Joardar V, Amedeo P, Denning D, Woloshuk C, Nierman W, Payne G (2009) Comparative genomics of Aspergillus flavus and
A. oryzae revealed nearly identical genomes but differences in gene expression. Phytopathol 99:S42

Ghosal S, Boswas K, Chakrabarti DK (1979) Toxic naphtho- $\gamma$-pyrones from Aspergillus niger. J Agric Food Chem 27:1347-1351

Gibbons JG, Salichos L, Slot JC, Rinker DC, McGary KL, King JG, Klich MA, Tabb DL, McDonald WH, Rokas A (2012) The evolutionary imprint of domestication on genome variation and function of the filamentous fungus Aspergillus oryzae. Curr Biol 22:14031409

Gilbert MK, Mack BM, Moore GG, Downey DL, Lebar MD, Joarder V, Losada L, Yu JJ, Nierman WC, Bhatnagar D (2018) Whole genome comparison of Aspergillus flavus L-morphotype strain NRRL 3357 (type) and S-morphotype strain AF70. PLoS ONE 13:e0199169

Gilbert MK, Mack BM, Wei Q, Bland JM, Bhatnagar D, Cary JW (2016) RNA sequencing of an $n s d C$ mutant reveals global regulation of secondary metabolite clusters in Aspergillus flavus. Microbiol Res $182: 150-161$

Gill-Serna J, García-Díaz M, González-Jaén M, Vázquez C, Patino B (2018) Description of an orthologous cluster of ochratoxin A biosynthetic genes in Aspergillus and Penicillium species. Int J Food Microbiol 268:35-43

Girol CG, Fisch KM, Heinekamp T, Günther S, Hüttel W, Piel J, Brakhage AA, Müller M (2012) Regio- and stereoselective oxidative phenol coupling in Aspergillus niger. Angew Chem Int Ed 51: 9788-9791

Gloer JB, TePaske MR, Sima JS, Wicklow DT, Dowd PF (1988) Antiinsectan aflavinine derivatives from the sclerotia of Aspergillus flavus. J Org Chem 53:5457-5460

Godet M, Munaut F (2010) Molecular strategy for identification in Aspergillus section Flavi. FEMS Microbiol Lett 304:157-168

Goris J, Konstantinidis KT, Klappenbach JA, Coenye T, Vandamme P, Tiedje JM (2007) DNA-DNA hybridization values and their relationship to whole-genome sequence similarities. Int J Syst Evol Microbiol 57:81-91

Gould RO, Simpson TJ, Walkinshaw MD (1981) Isolation and X-ray crystal structures of astellolides A and B, sesquiterpenoid metabolites of Aspergillus variecolor. Tetrahedron Lett 22:1047-1050

Grove JF (1972a) New metabolic products of Aspergillus flavus. Part. I. Asperentin, its methyl esters, and 5'-hydroxyasperentin. J Chem Soc Perkin Trans 1(1972):2400-2406

Grove JF (1972b) New metabolic products of Aspergillus flavus. Part. II. Asperflavin, anhydroasperflavin, and 5,7-dihydroxy-4methylphthalide. J Chem Soc Perkin Trans 1(1972):2406-2411

Grove JF (1973a) New metabolic products of Aspergillus flavus. Part. III. Biosynthesis of asperentin. J Chem Soc Perkin Trans 1(1973):26262429

Grove JF (1973b) New metabolic products of Aspergillus flavus. Part. IV. 4'-Hydroxyasperentin and 5'-hydroxyasperentin 8-methyl ether. J Chem Soc Perkin Trans 1(1973):2704-2706

Guida VO (1948) Activades antibioticas do Aspergillus flavus. Sobre diversas bacterias. Bol Soc Paulista Med Vet (Sao Paolo) 8:70-73

Gurupavithra S, Rajalakshmi A, Jayachitra A (2017) Optimization of fermentation conditions for red pigment production from Aspergillus flavus under submerged cultivation analyse its antioxidant properties. Indo Am J P Sci 2:2185-2194

Haenni AL, Lederer E, Barbier M (1962) Chimique biologique - sur la structure de l'aspergillomarasmine A. Compt Rend Hebd Scean Acad Sci 255:1476-1480

Haenni AL, Robert M, Vetter W, Roux L, Barbier M, Lederer E (1965) Structure chimique des aspergillomarasmins A et B. Helv Chim Acta 48:729-750

Hamasaki T, Kuwano H, Isono K, Hatsuda Y, Fukuyama K, Tsukihara T, Katsube Y (1975) New metabolite parasiticolide A, from Aspergillus parasiticus. Agric Biol Chem 39:749-751

Hamsa TAP, Ayres JC (1977) A differential medium for the isolation of Aspergillus flavus from cottonseed. J Food Sci 42:449-453 
Han X-M, Jiang HR, Xu J, Zhang J, Li F-Q (2017) Dynamic fumonisin $\mathrm{B} 2$ production by Aspergillus niger intended used in food industry in China. Toxins 9:217

Hanaka T, Ejiri K, Yamamoto H (2012) First synthesis of a natural isoxanthopterin glycoside, asperopterin A. Heterocycles 84:801813

Hanaka T, Yamamoto H (2013) First synthesis of asperopterin A, an isoxanthopterin glycoside from Aspergillus oryzae. Pteridines 24(special issue):3-6

Hanson JR (2008) The chemistry of fungi. The Royal Society of Chemistry, Cambridge

Happi GM, Kouam SF, Talontsi FM, Nkenfou CN, Longo F, Zuhlke S, Dounla-Meli C, Spiteller M (2015) A new dimeric naphtho-gammapyrone from an endophytic fungus Aspergillus niger AKRN associated with the roots of Entandrophragma congoense collected in Cameroun. Z Naturforsch Sect B J Chem Sci 70:625-630

Hardegger E, Liecht P, Jackman LM, Boller A, Plattner PA (1963) Welkstoffe und Antibiotika. 24. Mitteilung. Die Konstitution des Lycomarasmins. Helv Chim Acta 46:60-74

Hartley RD, Nesbitt BF, O'Kelley J (1963) Toxic metabolites of Aspergillus flavus. Nature 198:1056-1058

Hasegawa Y, Fukuda T, Hagimori K, Tomoda H, Omura S (2007) Tensyic acids, new antibiotics produced by Aspergillus niger FKI2342. Chem Pharm Bull 55:1338-1341

Hashimoto M, Nonaka T, Fujii I (2014) Fungal type III polyketide synthases. Nat Prod Rep 31:1306-1317

Hashimoto M, Seshime Y, Kitamoto K, Uchhiyama N, Goda Y, Fujii I (2013) Identification of csypyrone B2 and B3 as the minor products of Aspergillus oryzae type III polyketide synthase CsyB. Biomed Med Chem Lett 23:650-653

Hautbergue T, Puel O, Tadrist S, Meneghetti L, Pean M, Delaforge M, Debrauwer L, Oswald IP, Jamin EL (2017) Evidencing 98 secondary metabolites of Penicillium verrucosum using substrate isotopic labelling and high-resolution mass spectrometry. J Chromatogr B Anal Technol Biomed Life Sci 1071:29-43

He Y, Tain J, Chen X, Sun W, Zhu H, Li Q, Lei L, Yao G, Xue Y, Wang J, Li H, Zhang Y (2016) Fungal naphtho- $\gamma$-pyrones: potent antibiotics for drug-resistant microbial pathogens. Sci Rep 6:24291

He Y, Wang B, Chen W, Cox RJ, He J, Chen F (2018) Recent advances in reconstructing microbial secondary metabolites biosynthesis in Aspergillus spp. Biotechnol Adv 36:739-783

He FS, Zhang S, Qian FY, Zhang CL (1995) Delayed dystonia with striatal CT lucencies induced by a mycotoxin (3-nitropropionic acid). Neurology 456:2178-2183

Heathcote JG, Dutton MF (1969) New metabolites of Aspergillus flavus. Tetrahedron 10:1497-1500

Henrikson JC, Ellis TK, King JB, Cichewicz RH (2011) Reappraising the structures and distribution of metabolites from the black aspergilli containing uncommon 2-benzyl-4H-pyran-4-one and 2benzylpyridin-4(1H)-one systems. J Nat Prod 74:1959-1964

Henrikson JC, Hoover AR, Joyner PM, Cichewicz RH (2009) A chemical epigenetics approach for engineering the in situ biosynthesis of a cryptic natural product from Aspergillus niger. Org Biomol Chem 7: 435-438

Henry MH, Wyatt RD (2001) The toxicity of fumonisin $\mathrm{B}_{1}, \mathrm{~B}_{2}$ and $\mathrm{B}_{3}$, individually and in combination, in chicken embryos. Poultry Sci 80:401-407

Hesseltine CW, Shotwell OL, Smith M, Ellis JJ, Vandegraft E, Shannon G (1970). Production of various aflatoxins by strains of the Aspergillus flavus series. In: Herzberg M (ed) Proceedings of the first joint U.S.-Japan conference on toxic micro-organisms. Mycotoxins. Botulism. UJNR Joint Panels on Toxic Microorganisms and the U.S. Department of the Interior, Washington D.C., USA, 202-210

Heussner AH, Bingle LEH (2015) Comparative ochratoxin toxicity: a review of the available data. Toxins 7:4253-4282
Higuchi R (1956) Biosynthesis and destruction of flavin mononucleotide and flavine adenine dinucleotide by Aspergillus oryzae. I. Comparison of riboflavine and its derivatives biosynthesized by some species of Aspergillus oryzae. Vitamins (Kyoto) 11:559-561

Hiort J, Maksimenka K, Reichert M, Perović-Ottstadt S, Lin WH, Wray V, Steube K, Schaumann K, Weber H, Proksch P, Ebel R, Müller WEG, Bringmann G (2004) New natural products from the spongederived fungus Aspergillus niger. J Nat Prod 67:1532-1543

Holker JSE, Kagal SA, Mulheirn LJ, White PM (1966) Some new metabolites of Aspergillus versicolor and a revised structure for averufin. J Chem Soc Chem Commun 1966:911-913

Holm DK, Petersen LM, Klitgaard A, Knudsen PB, Jarzynska ZD, Nielsen KF, Gotfredsen CH, Larsen TO, Mortensen UH (2014) Molecular and chemical characterization of the biosynthesis of the 6-MSA-derived meroterpenoid yanuthone D in Aspergillus niger. Chem Biol 21:519-529

Holzapfel CW, Bredenkamp MW, Snyman RM, Boeyens JCA, Allen CC (1990) Cyclopiamide, an isoindolo[4,6-CD)indole from Penicillium cyclopium. Phytochem 29: 639-642.

Hong S-B, Lee M, Kim D-H, Chung S-H, Shin H-D, Samson RA (2013a) The proportion of non-aflatoxigenic strains of the Aspergillus flavus/ oryzae complex from Meju by analyses of the aflatoxin biosynthetic genes. J Microbiol 51:766-772

Hong S-B, Lee MM, Kim D-H, Varga J, Frisvad JC, Perrone G, Gomi K, Yamada O, Machida M, Houbraken J, Samson RA (2013b) Aspergilllus luchuensis, an industrially important black Aspergillus in East Asia. PLoS ONE 8:e63769

Horn BW, Dorner JW (2001) Effect of competition and adverse culture conditions on aflatoxin production by Aspergillus flavus through successive generations. Mycologia 94:741-751

Houbraken J, de Vries RP, Samson RA (2014) Modern taxonomy of biotechnologically important Aspergillus and Penicillium species. Adv Appl Microbiol 86:199-249

Hu X, Xia Q-W, Zhao Y-Y, Zheng Q-H, Liu Q-Y, Chen L, Zhang Q-Q (2014a) Speradines B-E, four novel tetracyclic oxindole alkaloids from the marine-derived fungus Aspergillus oryzae. Heterocycles 89:1662-1669

Hu X, Xia Q-W, Zhao Y-Y, Zheng Q-H, Liu Q-Y, Chen L, Zhang Q-Q (2014b) Speradines F-H, three new oxindole alkaloids from the marine-derived fungus Aspergillus oryzae. Chem Pharm Bull 62: 942-946

Hummel BCW (1956) Isolation and partial characterization of flavicidic acid, phytotoxic metabolite of Aspergillus flavus. Dissertation Abstr 16:1332-1333

Huson DH, Scornavacca C (2012) Dendroscope 3: an interactive tool for rooted phylogenetic trees and networks. Syst Biol 61:1061-1067

Hüttel W, Müller M (2007) Regio- and steroselective intermolecular oxidative phenol coupling in kotanin biosynthesis by Aspergillus niger. ChemBioChem 8:521-529

Iizuka A, Iida M (1962) Maltoryzin, a new toxic metabolite produced by a strain of Aspergillus oryzae var. microsporus isolated from the poisonous malt sprout. Nature 196:681-682

Inokoshi J, Shiomi K, Masuma R, Tanaka H, Yamada H, Omura S (1999) Funalenone, a novel collagenase inhibitor produced by Aspergillus niger. J Antibiot 52:1095-1100

Itoh Y, Takahashi S, Haneishi T, Arai M (1989) Structure of heptelidic acid, a new sesquiterpene antibiotic from fungi. J Antibiot 33:525526

Iwamoto T, Hirota A, Shima S, Sakai H, Isogai A (1985) Nigerazine A, an isomer of nigerazine B, from Aspergillus niger. Agric Biol Chem 49: 3323-3325

Iwamoto T, Shima S, Hirota A, Isogai A, Sakai H (1983) Nigerazine B, a new metabolite from Aspergillus niger screening, isolation, and chemical and biological properties. Agric Biol Chem 47:739-743

Iwasaki T, Kosikowski FV (1973) Production of $\beta$-nitropropionic acid in foods. J Food Sci 38:1162-1165 
Jahn F (1977) Toxicity and production of oxalic acid of an Aspergillus niger strain from mold hay. Wien Tierartl Monatschr 64:79-82

Jansen BJM, de Groot A (1990) The occurrence and biological activity of drimane sesquiterpenoids. Nat Prod Rep 8:309-318

Jansen BJM, de Groot A (2004) The occurrence and biological activity of drimane sesquiterpenoids. Nat Prod Rep 21:449-477

Jarvis BB, Miller JD (2005) Mycotoxins as harmful indoor air contaminants. Appl Microbiol Biotechnol 66:367-372

Jefferson WE Jr (1967a) Steroids and other factors influencing the accumulation of asperenone and fermentation acids by Aspergillus niger in replacement cultures. Biochem 6:3484-3488

Jefferson WE Jr (1967b) The isolation and characterization of asperenone, a new phenylpolyene from Aspergillus niger. Biochemistry 6:3479-3484

Jennings MA, Williams TI (1945) Production of kojic acid by Aspergillus effusus Tiraboschi. Nature 155:302

Johnson JR, Robinson BL, Ali SF, Binienda Z (2000) Dopamine toxicity following long term exposure to low doses of 3-nitropropionic acid (3-NPA) in rats. Toxicol Lett 116:113-118

Jørgensen TR (2007) Identification and toxigenic potential of the industrally important fungi, Aspergillus oryzae and Aspergillus sojae. J Food Prot 70:2916-2934

Jørgensen TR, Park J, Arentshorst M, van Welzen AM, Lamers G, vanKuyk PA, Damvel RA, van den Hondel CAM, Nielsen KF, Frisvad JC, Ram AFJ (2011) The molecular and genetic basis of conidial pigmentation in Aspergillus niger. Fungal Gen Biol 48: 544-553

Juvvadi PR, Seshime Y, Kitamoto K (2005) Genomics reveal traces of fungal phenylpropanoid-flavanoid metabolic pathway in the filamentous fungus Aspergillus oryzae. J Microbiol 43:457-486

Kaneko Y, Sanada M (1969) Studies on the fluorescent substances produced by Aspergillus fungi. VIII. Purification and isolation of asperopterin B and chemical properties of asperopterin B and A. J Ferment Technol 47:8-19

Kang D, Kim J, Choi JN, Liu K-H, Lee CH (2011) Chemotaxonomy of Trichoderma spp. using mass spectrometry metabolite profiling. J Microbiol Biotechnol 21:5-13

Kato A, Saeki T, Suzuki S, Ando K, Tamura G, Arima K (1969) Oryzachlorin, a new antifungal antibiotic (Studies on antiviral and antitumor Antibiotics XVIII). J Antibiot 22:322-326

Kato N, Tokuoka M, Shinohara Y, Kaeatani M, Uramoto M, Seshime Y, Fujii I, Kitamoto K, Takahashi T, Takahashi S, Koyama Y, Osada H (2011) Genetic safeguard against mycotoxin cyclopiazonic acid production in Aspergillus oryzae. ChemBioChem 12:1376-1382

Kayoko M (1985) Reduction of ochratoxin a toxicity in mice treated with phenylalanine and phenobarbital. Toxicol Lett 25:1-5

Kim JH, Lee CH (2009) Heptelidic acid, a sesquiterpene lactone, inhibits apoptosis in human leukemia U937 cells. J Microbiol Biotechnol 19:787-791

Kim K-W, Sugawara F, Yoshida S, Murofuschi N, Takahashi N, Curtis RW (1993) Structure of malformin B, a phytotoxic metabolite produced by Aspergillis niger. Biosci Biotech Biochem 57:787-791

Kimura Y, Nishibe M, Nakajima H, Hamasaki T, Shigemitsu N, Sugawara F, Stout TJ, Clardy J (1992) Emeniveol; a new pollen growth inhibitor from the fungus, Emericella nivea. Tetrahedron Lett 33:6987-6990

King AM, Reid-Yu SA, Wang W, King DT, De Pascale G, Strynadka NC, Walsch TR, Coombes BK, Wright GD (2014) Aspergillomarasmine A overcomes metallo- $\beta$-lactamase antibiotic resistance. Nature 510: 503-506

Kinoshita S, Akita S, Saito K (1961) L-glutamic acid. Japanese patent no. 3171, Apr. 14.

Kishimoto S, Tsunematsu Y, Sato M, Watanabe K (2017) Elucidation of biosynthetic pathways of natural products. Chem Rec 17:10951108
Kistner HE Sr (1962) Sucrose fermentation of Aspergillus flavus-oryzae. U.S. patent no. 3,043,748, July 10 .

Kiyota T, Hamada R, Sakamoto K, Iwashita K, Yamada O, Mikami S (2011) Aflatoxin non-productivity of Aspergillus oryzae caused by loss of function of the aflJ gene product. J Biosci Bioeng 111:512517

Kjærbølling I, Vesth TC, Frisvad JC, Nybo JL, Theobald S, Kuo A, Bowyer P, Matsuda Y, Mondo S, Lyhne EK, Kogle M, Clum A, Lipzen A, Salamov A, Ngan C, Daum C, Chiniquy J, Barry K, LaButti K, Haridas S, Simmons B, Magnuson J, Mortensen U, Larsen T, Grigoriev I, Baker S, Andersen MR (2018) Linking secondary metabolites to gene clusters through genome sequencing of six diverse Aspergillus species. Proc Nat Acad Sci, USA 115:E753E761

Klausmeyer P, McCloud TG, Tucker KD, Cardellina JH II, Shoemaker RH (2005) Aspirochlorine class compounds from Aspergillus flavus inhibit azole-resistant Candida albicans. J Nat Prod 68:1300-1302

Klich MA, Mullaney EJ (1987) DNA restriction enzyme gragment polymorphiosms as a tool for rapid differentiation of Aspergillus flavus from Aspergillus oryzae. Exp Mycol 11:170-175

Klich MA, Pitt JI (1985) The theory and practice of distinguishing species of the Aspergillus flavus group. In: Samson RA, Pitt JI (eds) Advances in Penicillium and Aspergillus systematics. Plenum Press, New York, pp 211-220

Klich MA, Pitt JI (1988) Differentiation of Aspergillus flavus from A. parasiticus and other closely related species. Trans Brit Mycol Soc 91:99-108

Klitgaard A, Nielsen JB, Frandsen RJN, Andersen MR, Nielsen KF (2015) Combining stabel isotope labelling and molecular networking for biosynthetic pathway characterization. Anal Chem 87:6520 6526

Kobayashi T (1966) Food poisoning. Chiba Daikage Fuhai Kenkyosho Hokoku 19:92-107

Kobayashi T, Abe K, Asai K, Gomi K, Juvvadi PR, Kato M, Kitamoto K, Takeuchi M, Machida M (2007) Genomics of Aspergillus oryzae. Biosci Biotechnol Biochem 71:646-670

Kobayashi K, Shimizu H, Itho M, Suginome H (1990) An efficient synthesis of 5,7-dihydroxy-4-methylisobenzofuran-1-(3H)-one, a metabolite of Aspergillus flavus and a key intermediate in the synthesis of mycophenolic acid. Bull Chem Soc Japan 63:2435-2437

Kobbe B, Cushman M, Wogan GN, Demain AL (1977) Production and bacterial activity of malformin C, a toxic metabolite of Aspergillus niger. Appl Environ Microbiol 33:996-997

Koch L, Lodin A, Herold I, Ilan M, Carmeli S, Yarden O (2014) Sensitivity of Neurospora crassa to a marine-derived Aspergillus tubingensis anhydride exhibiting antifungal activity that is mediated by the MAS1 protein. Mar Drugs 12:4713-4731

Kocsubé S, Perrone G, Magistà D, Houbraken J, Varga J, Szigeti G, Hubka V, Hong S-B, Frisvad JC, Samson RA (2016) Aspergillus is monophyletic: evidence from multiple gene phylogenies and extrolite profiles. Stud Mycol 85:199-213

Kodukula K, Arcuri M, Cutrone JQ, Hugill RM, Lowe SE, Pirnik DM, Shu Y-Z, Fernandes PV, Seethala R (1995) BMS-192548, a tetracyclic binding inhibitor of neuropeptide $\mathrm{Y}$ receptors, from Aspergillus niger WB2346. II. Taxonomy, fermentation, isolation and biological activity. J Antibiot 48:1055-1059

Koiso Y, Iwasaki S, Hanaoka K, Kobayashi T, Sonoda R, Fujita Y, Yaegashi H, Sato Z (1994) Ustiloxins, antimitotic cyclic peptides from false smut balls on rice panicles caused by Ustilaginoidea virens. J Antibiot 47:765-773

Koiso Y, Natori M, Iwasaki S, Sato S, Sonoda R, Fujita Y, Yaegashi H, Sato Z (1992) Ustiloxin: a phytotoxin and a mycotoxin from false smut balls on rice panicles. Tetrahedron Lett 33:4157-4160

Komagata D, Fujita S, Yamashita N, Saito S, Morino T (1996) Novel neuritogenic activities of pseurotin A and penicillic acid. J Antibiot 49:958-959 
Koteva K, King AM, Capretta A, Wright GD (2016) Total synthesis and activity of the metallo- $\beta$-lactamase inhibitor aspergillomarasmin A. Angew Chem Ind Ed 55:2210-2212

Kozakiewicz Z, Frisvad JC, Hawksworth DL, Pitt JI, Samson RA, Stolk AC (1992) Proposals for nomina specifica conservanda and rijicienda in Aspergillus and Penicillium (Fungi). Taxon 41:109-113

Közégi T, Poór M (2016) Ochratoxin A: molecular interactions, mechanisms of toxicity and prevention at the molecular level. Toxins 8:111

Kredics L, Varga J, Antal S, Samson RA, Kocsube S, Narendran V, Bhaskar M, Manoharan C, Vagvolgyi C, Manikandan P (2008) Black aspergilli in tropical infections. Rev Med Microbiol 19:65-78

Kozlovskii AG, Solov'yeva TF, Bukhtiyarov YE, Shurukhin YV, Sakharovskii VG, Adanin VM, Nefedova MY, Pertsova RN, Tokarev VG, Golovleva LE (1990) Secondary metabolites of new soil strains of microscopic fungi from the genera Aspergillus and Penicillium. Microbiology (Moscow) 59:409-415

Kubicek CP, Druzhinina IS (2016) Trichoderma mycoses and mycotoxins. In: Paterson RRM, Lima N (eds) Molecular biology of food and water borne mycotoxigenic and mycotic fungi. CRC Press, Boca Raton, pp 521-538

Kupfahl C, Michalka A, Lass-Flörl C, Fischer G, Haase G, Ruppert T, Geginat G, Hof H (2008) Gliotoxin production by clinical and environmental Aspergillus fumigatus strains. Int J Med Microbiol 298: 319-327

Lallouette P (1962) Extraction and purification of a growth factor. French patent no. 1,284,511 (June 18)

Larsen TO, Smedsgaard J, Nielsen KF, Hansen ME, Frisvad JC (2005) Phenotypic taxonomy and metabolite profiling in microbial drug discovery. Nat Prod Rep 22:672-695

Lederer E (1962) Chimie biologique -sur la structure de l'aspergillomarasmine A. C R Hebd Seance Acad Sci 255:14761485

Lee M, Cho J-Y, Lee YG, Lee HJ, Lim S-I, Lee S-Y, Nam Y-D, Moon J-H (2016) Furan, phenolic, and heptelidic acid derivatives produced by Aspergillus oryzae. Food Sci Biotechnol 25:1259-1264

Lee JH, Jo EH, Hong EJ, Kim KM, Lee I (2014) Safety evaluation of filamentous fungi isolated from industrial Doenjang Koji. J Microbiol Biotechnol 24:1397-1404

Lee CZ, Liou GY, Yuan GF (2006b) Comparison of aflR gene sequences of strains in Aspergillus section Flavi. Microbiology-SGM 152: $161-170$

Lee KC, Tam EWT, Lo KC, Tsang AKL, Lau CCY, To KKW, Chan JFW, Lam CW, Yuen KY, Lau SKP, Woo PCY (2015) Metabolomics analysis reveals specific novel tetrapeptide and potential antiinflammatory metabolites in pathogenic Aspergillus species. Int $\mathrm{J}$ Mol Sci 16:13850-13867

Lee YH, Tominaga M, Hayashi R, Sakamoto K, Yamado O, Akito O (2006a) Aspergillus oryzae strains with a large deletion of the aflatoxin biosynthetic homologous gene cluster differentiated by chromosomal breakage. Appl Microbiol Biotechnol 72:339-345

Leite MAF, Sarragiotto MH, Imamura PM, Marsaioli AJ (1986) Absolute configuration of drim-9(11)-en-8-ol from Aspergillus oryzae. J Org Chem 51:5409-5410

Leutou AS, Yun K, Son BW (2016) Induced production of 6,9dibromoflavasperone, a new radical scavenging naphthopyranone in the marine-mitflat-derived fungus Aspergillus niger. Arch Pharm Res 39:806-810

Lewis RE, Wiederhold NP, Lionakis MS, Prince RA, Kontoyiannis DP (2005) Frequency and species distribution of gliotoxin-producing Aspergillus isolates recovered from patients at a tertiary-care cancer center. J Clin Microbiol 43:6120-6122

Li Y, Chooi Y-H, Sheng Y, Valentine JS, Tang Y (2011) Comparative characterization of fungal anthracenone and naphthacenedione biosynthetic pathways reveals an $\alpha$-hydroxylation-dependent Claisenlike cyclization catalyzed by a dimanganese thioesterase. J Amer Chem Soc 133:15773-17785
Li D-H, Han T, Guan L-P, Bai J, Zhao N, Li Z-L, Wu X, Hua H-M (2016) New naphthopyrones from the marine-derived fungus Aspergillus niger $2 \mathrm{HL}-\mathrm{M}-8$ and their in vitro antiproliferative activity. Nat Prod Res 30:1116-1122

Li X-B, Li Y-L, Zhou J-C, Yuan H-Q, Wang X-N, Lou H-X (2015) A new diketopiperazine heterodimer from an endophytic fungus Aspergillus niger. J Asian Nat Prod Res 17:182-187

Li X-B, Xie F, Liu S-S, Li Y, Zhou JC, Liu YQ, Yuan H-Q, Lou H-X (2013) Naphtho- $\gamma$-pyrones from endophyte Aspergillus niger occurring in the liverwort Heteroscyphus tener (Steph.) Schiffn. Chem Biol 10:1193-2001

Liljegren K, Svendsen A, Frisvad JC (1988) Mycotoxins and exoenzyme production by members of Aspergillus section Flavi: an integrated taxonomic approach to their classification. Proc Jpn Assoc Mycotoxicol Suppl 1:35-36

Lind AL, Wisecaver JH, Lameiras C, Wiemann P, Palmer JM, Keller NP, Ridrogues F, Goldman GH, Rokas A (2017) Driver of genetic diversity in secondary metabolic gene clusters within a fungal species. PLOS Biol 15:e2003583

Lind AL, Wisecaver JH, Smith TD, Feng X, Calvo AM, Rokas A (2015) Examining the evolution of the regulatory circuit controlling secondary metabolism and development in the fungal genus Aspergillus. PLoS Genet 11:e1005096

Liu L, Bao L, Wang L, Ma K, Han J, Yang Y, Liu R, Ren J, Yin W, Wang W, Liu H (2018) Asperorydines A-M: Prenylated tryptophanderived alkaloids with neurotropic effects from Aspergillus oryzae. J Org Chem 83:812-822

Liu D, Li X-M, Li C-S, Gao S-S, Shang Z, Proksch P, Huang C-G, Wang B-G (2011) Nigerapyrones A-H, $\alpha$-pyrone derivatives from the marine mangrove-derived endophytic fungus Aspergillus niger MA132. J Nat Prod 74:1787-1791

Liu D, Li X-M, Li C-S, Wang B-G (2013) Nigerasterols A and B, antiproliferative sterols from the mangrove-derived endophytic fungus Aspergillus niger MA-132. Helv Chim Acta 96:1055-1061

Liu XJ, Luo XY, Hu WJ (1989) Arthrinium spp and the etiology of deteriorated sugarcane poisoning. In: Natori S, Ueno Y (eds) Mycotoxins and phycotoxins 88, vol 10. Elsevier, London. Bioactive Molecules, pp 109-118

Liu C, Tagami K, Minami A, Matsumoto T, Frisvad JC, Suzuki H, Ishikawa J, Gomi K, Oikawa H (2015) Reconstitution of biosynthetic machinery for highly elaborated indole diterpene penitrem. Angew Chem Int Ed 54:5748-5752

Logrieco A, Feracane R, Haidukowsky M, Cozzi G, Visconti A, Ritieni A (2009) Fumonisin B2 production by Aspergillus niger from grapes and natural occurrence in must. Food Addit Contam Part A 26: $1495-1500$

Lopez Diaz TM, Flannigan B (1997) Production of patulin and cytochalasin E by Aspergillus clavatus during malting of barley and wheat. Int J Food Microbiol 35:129-136

Lu S, Tian J, Sun W, Meng J, Wang X, Fu X, Wang A, Lai D, Liu Y, Zhou $\mathrm{L}$ (2014) Bis-naphtho- $\gamma$-pyrones from fungi and their bioactivities. Molecules 19:7169-7188

Lu X-T, Zhang E-X, Yin S-T, Fan L-H, Hu H-B (2017) Methylseleninic acid prevents patulin-induced hepatotoxicity and nephrotoxicity via the inhibition of oxidative stress and inactivation of p53 and MAPKs. J Agric Chem 65:5299-5305

Lubna AS, Hamayun M, Gul H, Lee I-J, Hussain A (2018) Aspergillus niger CSR 3 regulates plant hormones and secondary metabolites by producing gibberellins and indoleacetic acid. J Plant Interact 13: $100-111$

Luk KC, Kobbe B, Townsend JM (1977) Production of cyclopiazonic acid by Aspergillus flavus Link. Appl Environ Microbiol 33:211212

Lv Y, Xiao J, Pan L (2014) Type III polyketide synthase is involved in the biosynthesis of protocatechuic acid in Aspergillus niger. Biotechnol Lett 36:2303-2310 
Lv Y, Zhou F, Wang B, Pam L (2015) Morphological transitions under oxidative stress in response to metabolite formation in Aspergillus niger. Biotechnol Lett 37:6012-6018

Ma Y, Li T, Ma C (2016) A new pyrone derivative from an endophytic Aspergillus tubingensis of Lycium ruthenicum. Nat Prod Res 30: 1499-1503

Ma X, Peng J, Wu G, Zhu T, Li G, Gu Q, Li D (2015) Speradines B-D, oxygenated cyclopiazonic acid alkaloids from the sponge-derived fungus Aspergillus flavus MXH-X104. Tetrahedron 71:3522-3527

MacDonald JC (1961) Biosynthesis of aspergillic acid. J Biol Chem 236: 512-514

MacDonald JC (1962) Biosynthesis of hydroxyaspergillic acid. J Biol Chem 237:1977-1981

MacDonald JC (1973) Toxicity, analysis, and production of aspergillic acid and its analogs. Can J Biochem 51:1311-1315

Machida M, Asai K, Sano M, Tanaka T, Kumagai T, Terai G, Kusumoto K, Arima T, Akita O, Kashiwagi Y, Abe K, Gomi K, Horiuchi H, Kitamoto K, Kobayashi T, Takeuchi M, Denning DW, Galaghan JE, Nierman WC, Yu JJ, Archer DB, Bennett JW, Bhatnagar D, Cleveland TE, Fedorova ND, Gotoh O, Horikawa H, Hosoyama A, Ichinomaya M, Igarashi R, Iwashita K, Juvvadi PR, Kato M, Kato Y, Kin T, Kokubun A, Maede H, Maeyama N, Maruyama J, Nagasaki H, Nakajima T, Oda K, Okada K, Paulsen I, Sakamoto K, Sawano T, Takahashi M, Takase K, Terabayashi Y, Wortman JR, Yamada O, Yamagata Y, Anazawa H, Hata Y, Koide Y, Komori T, Koyama Y, Minetoki T, Suharnan S, Taanaka A, Isono K, Kuhara S, Ogasawara N, Kukuchi H (2005) Genome sequencing and analysis of Aspergillus oryzae. Nature 438:1157-1161

Machida M, Yamada O, Gomi K (2008) Genomics of Aspergillus oryzae: learning from the history of koji mold and exploration of its future. DNA Res 15:173-183

Manonmani HK, Sreektaniah KR (1984) Pigment production by a strain of Aspergillus sp. J Food Sci Technol 21:195-197

Månsson M, Klejnstrup ML, Phipps RK, Nielsen KF, Frisvad JC, Gotfredsen CH, Larsen TO (2010) Isolation and NMR characterization of fumonisin $\mathrm{B}_{2}$ and $\mathrm{B}_{6}$, a new fumonisin from Aspergillus niger. J Agric Food Chem 58:949-953

Manzanares-Miralles L, Sarikaya-Bayram Ö, Smith EB, Dolan SK, Bayram Ö, Jones GW, Doyle S (2016) Quantitative proteomcis revelas the mechanism and consequence of gliotoxin-mediates dysregulation of the methionine cycle in Aspergillus niger. J Proteomics 131:149-162

Marston RQ (1949) Production of kojic acid from Aspergillus lutescens. Nature 164:961

Martinez D, Berka RM, Henrissat B, Saloheimo M, Arvas M, Baker SE, Chapman J, Chertkov O, Coutinho PM, Cullen D, Danchin EG, Grigoriev IV, Harris P, Jackson M, Kubicek CP, Han CS, Ho I, Larrondo LF, de Leon AL, Magnuson JK, Merino S, Misra M, Nelson B, Putnam M, Robbertse B, Salamov AA, Scmoll M, Terry A, Thayer N, Westerhom-Parvinen A, Sloch CL, Yao J, Barbote R, Nelson MA, Detter C, Bruce D, Kuske CR, Xie G, Richardson P, Rokshar H, Lucas SM, Rubin EM, Dunn-Coleman N, Ward M, Brettin TS (2008) Genome sequencing and analysis of the biomass-degrading fungus Trichoderme reesei (syn. Hyprocrea jecorina). Nat Biotechnol 26:553-560

Martinez-Luis S, Cherigo L, Arnold E, Spadafora C, Gerwick WH, Cubila-Rios L (2012) Antiparasitic and anticancer constituents of the endophytic fungus Aspergillus sp. strain F1544. Nat Prod Commun 7:165-168

Marui J, Ohashi-Kunihiro S, Ando T, Nishimura M, Koike H, Machida M (2010) Penicillin biosynthesis in Aspergillus oryzae and its overproduction by genetic engineering. J Biosci Bioeng 110:8-11

Massi FP, Sartori D, Ferranti L d S, Iamanaka BT, Taniwaki MH, Vieira MKLC, Fungaro MHP (2016) Prospecting for the incidence of genes involved in ochratoxin and fumonisin biosynthesis in
Brazilian strains of Aspergillus niger and A. welwitschiae. Int $\mathrm{J}$ Food Microbiol 221:19-28

Matsumara T, Sunazuka T, Hirose T, Ishiyama A, Namatame M, Fukuda T, Tomoda H, Otoguro K, Omura S (2008) Synthesis and biological properties of tensuyic acid $\mathrm{B}, \mathrm{C}$, and $\mathrm{E}$, and investigation of the optical purity of natural tensyuic acid B. Tetrahedron 64:7369-7377

Matsuo M (1997) In vivo antioxidant activity of Okara koji, a fermented okara, by Aspergillus oryzae. Biosci Biotech Biochem 61:19681972

Matsuura S, Yamamoto M, Kaneko Y (1972) The structure of the pteridine glycoside from Aspergillus oryzae. Bull Chem Soc Japan 45: 492-495

Mazzaferro LS, Hüttel W, Fries A, Müller M (2015) Cytochrome P450catalyzed region- and stereoselective phenol coupling of fungal natural products. J Am Chem Soc 137:12289-12295

McCorkindale NJ, Wright JLC, Brian PW, Clarke SM, Hutchinson SA (1968) Canadensolide - an antifungal metabolite of Penicillium canadense. Tetrahedron Lett 9:727-730

McGivan JD, Chappell JB (1970) Avenaciolide - a specific inhibitor of glutamate transport in rat liver mitochondria. Biochem J 116:P37

McKean C, Tang L, Tang M, Billam M, Wang Z, Theodorakis CW, Kendall RJ, Wang JS (2006) Comparative acute and combinative toxicity of aflatoxin $\mathrm{B}_{1}$ and fumonisin $\mathrm{B}_{1}$ in animals and human cells. Food Chem Toxicol 44:868-876

McKee CM, MacPhillamy HB (1943) An antibiotic substance produced by submerged cultivation of Aspergillus flavus. Proc Soc Exptl Biol Med 53:247-248

McKee CM, Rake G, Houck CL (1944) Studies on Aspergillus flavus. II. The production and properties of a penicillin-like substanceflavididin. J Bacteriol 47:187-197

Mehedi MAU, Molla AH, Khondar P, Sultana S, Islam MA, Rashid MA, Chowdhury R (2010) Pseurotin A: an antibacterial secondary metabolite from Aspergillus fumigatus. Asian J Chem 22:2611-2614

Meng J, Sun W, Mao Z, Xu D, Wang X, Lu S, Lai D, Liu Y, Zhou L, Zhang G (2015) Main ustilaginoidins and their distribution in rice false smut balls. Toxins 7:4023-4034

Miknis GF, Williams RW (1993) Total synthesis of (+)-aspirochlorin. J Am Chem Soc 115:536-547

Minami A, Liu CW, Oikawa H (2016) Total biosynthesis of fungal indole terpenes using cell factories. Heterocycles 92:397-421

Ming L (1995) Moldy sugarcane poisoning - a case report with a brief review. J Toxicol Clin Toxicol 33:363-367

Mituzani S, Komori K, Taniguchi T, Monde K, Kuramochi K, Tsubaki K (2016) A bioinspired synthesis of (+)-rubramide, (+)-flavipucine, and (+)-isoflavipucine. Angew Chem Int Ed 55:9553-9556

Miyake Y, Ito C, Itoigawa M, Osawa T (2007) Isolation of the antioxidant pyranonigrin A from rice mold starters used in the manufacturing process of fermented foods. Biosci Biotechnol Biochem 71:25152521

Miyake Y, Mocchizuki M, Ito C, Itoigawa M, Osawa T (2008) Antioxidative pyranonigrins in rice mold starters and their suppressive effect on the expression of blood adhesion molecules. Biosci Biotech Biochem 72:1580-1585

Mogensen JM, Frisvad JC, Thrane U, Nielsen KF (2010) Production of fumonisin $\mathrm{B}_{2}$ and $\mathrm{B}_{4}$ by Aspergillus niger on grapes and raisins. $\mathrm{J}$ Agric Food Chem 58:954-958

Mogensen JM, Varga J, Thrane U, Frisvad JC (2009) Aspergillus acidus from Puerh tea and black tea does not produce ochratoxin A and fumonisin $\mathrm{B}_{2}$. Int J Food Microbiol 132:141-144

Mogi M, Nakayima S, Iguchi N (1952) Fortified miso (fermented soybean paste). II. Riboflavin production by ultraviolet-induced mutants of Aspergillus oryzae. J. Ferment Technol 30:363-369

Mogi M, Nakayima S, Yoshida F (1951) Fortified miso (fermented soybean paste). I. Trial brewing of miso with riboflavine-producing strain of Aspergillus oryzae. J Ferment Technol 29:302-310 
Monti F, Ripamonti F, Hawser SP, Islam K (1999) Aspirochlorine: a highly selective and potent inhibitor of fungal protein synthesis. $\mathrm{J}$ Antibiot 52:311-318

Morton HE, Kocholaty W, Junowicz-Kocholaty R, Kelner A (1945) Toxicity and antibiotic activity of kojic acid produced by Aspergillus luteo-virescens. J Bacteriol 50:579-583

Moule Y, Moreau S, Bousquet JF (1977) Relationship between the chemical structure and the biological properties of some ermophilane compounds related to PR-toxin. Chem Biol Interact 17:185-192

Munkvold GP, Weieneth L, Proctor RH, Busman M, Blandino M, Susca A, Logrieco A, Moretti A (2018) Pathogenicity of fumonisinproducing and nonproducing strains of Aspergillus species in section Nigri to maize ears and seedlings. Plant Dis 102:282-291

Murakami H (1971) Classification of the koji mould. J Gen Appl Microbiol 17:281-309

Murakami H (1979) Summary and description of species of the black aspergilli. Taxonomic studies on Japanese Industrial strains of the Aspergillus (Part 33). J Brew Soc Japan 74:854-858

Mushtaq S, Abbasi BH, Uzair B, Abbasi R (2018) Natural products as reservoirs of novel therapeutic agents. EXCLI J 17:420-451

Nagano N, Umemura M, Izumikawa M, Kawano J, Ishii T, Kikuchi M, Tomii K, Kumagai T, Yoshimi A, Machida M, Abe K, Shin-ya K, Asai K (2016) Class of cyclic ribosomal peptide synthetic genes in filamentous fungi. Fungal Genet Biol 86:58-70

Nair MG (1998) Fumonisin and human health. Ann Tropic Paed 18:S47$\mathrm{S} 52$

Nakamura S (1960) Muta-aspergillic acid, a new growth inhibitant against hiochi-bacteria. Bull Agric Chem Soc Jpn 24:629-630

Nakamura S (1961) The structure of muta-aspergillic acid. Agric Biol Chem 25:74-75

Nakamura S, Shimoda C (1954) Studies on antibiotic substance oryzacidin, produced by Aspergillus oryzae. Part 5. Existence of $\beta$-nitropropionic acid. J Agr Chem Soc Japan 28:909-913

Nakamura S, Shiro T (1959a) Studies on growth inhibition of hiochibacteria, specific saprophytes of sake. 4. Hydroxyaspergillic acid as a growth inhabitant against hiochi-bacteria. Bull Agric Chem Soc Jpn 23:418-427

Nakamura S, Shiro T (1959b) Hydroxyaspergillic acid as growth inhabitant against hiochi-bacteria (Studies on growth inhibition of hiochibacteria, specific saprophytes of sake. 4). Bull Agric Chem Soc Jpn 23:65-67

Nakazawa R (1907) On the koji fungus. Aspergillus awamori. Rept Inst Gov Res Formosa 1

Nakazawa M, Uehara T, Nomura Y (1997) Koningic acid (a potent glyceraldehyde-3-phosphate dehydrogenase inhibitor) induced fragmentation and condensation of DNA in NG108-15 cells. J Neurochem 68:24932499

Nicholson MJ, Koulman A, Monahan BJ, Pritchard BL, Payne GA, Scott B (2009) Identification of two aflatrem biosynthesis gene loci in Aspergillus flavus and metabolic engineering of Penicillium paxilli to elucidate their function. Appl Environ Microbiol 75:7469-7481

Nielsen KF, Gräfenham T, Zafari D, Thrane U (2005) Trichothecene production by Trichoderma brevicompactum. J Agric Food Chem 53:8190-8196

Nielsen JC, Grijseels S, Prigent S, Ji B, Dainat J, Nielsen KF, Frisvad JC, Workman M, Nielsen J (2017) Global analysis of biosynthetic gene clusters reveals vast potential of secondary metabolite production in Penicillium species. Nat Microbiol 2:17044

Nielsen KF, Mogensen JM, Johansen M, Larsen TO, Frisvad JC (2009) Review of secondary metabolites and mycotoxins from the Aspergillus niger group. Anal Bioanal Chem 395:1225-1246

Nierman WC, Yu J, Fedorova-Adams ND, Losada L, Cleveland TE, Bhatnagar D, Bennett JW, Dean R, Payne GA (2015) Genome sequence of Aspergillus flavus NRRL 3357, a strain that causes aflatoxin contamination of food and feed. Genome Announc 3:e00168e00115
Nishie K, Porter JK, Cole RJ, Dorner JW (1985) Neurochemical and pharmacological effects of cyclopiazonic acid, chlorpromazine and reserpine. Res Commun Psychol Psych Behav 10:291-302

Nishimura A, Okamoto S, Yoshizako F, Morishima I, Ueno T (1991) Stimulatory effect of acetate and propionate on aspergillic acid formation by Aspergillus oryzae A21. J Ferment Bioeng 72:461-464

Nishimura I, Shinohara Y, Oguma T, Koyama Y (2018) Survival strategy of the salt-tolerant lactic acid bacterium, Tetragenococcus halophilus, to counteract koji mold, Aspergillus oryzae, in soy sauce brewing. Biosci Biotechnol Biochem 82:1437-1443

Niu J, Arenthorst M, Nair PDS, Dai Z, Baker S, Frisvad JC, Nielsen KF, Punt PJ, Ram A (2016) Identification of a classical mutant in the industrial host Aspergillus niger by systems genetics: LaeA is required for citric acid production and regulates the formation of some secondary metabolites. G3: Gen Genom Genet 6:193-204

Nonaka N, Asai Y, Nishio M, Takahashi K, Okuda T, Tanaka S, Suita T, Ohnuki T, Komatsubara S (1997) TMC-2A, -2B and -2C, new dipeptidyl peptidase IV inhibitors produced by Aspergillus oryzae A374. I. Taxonomy of producing strain, fermentation, and biochemical properties. J Antibiot 50:646-652

Nozawa K, Nakajima S, Kawai K (1988) Isolation and structures of indoloterpenes, possible biosynthetic intermediates to the tremorgenic mycotoxin, paxilline, from Emericella striata. J Chem Soc Perkin Trans I 1988:2607-2610

Nozawa K, Sekita S, Harada M, Udagawa S, Kawai K (1989) Isolation and structures of two new indoloterpenes related to aflavinine from a microsclerotium-producing strain of Aspergillus flavus. Chem Pharm Bull 37:626-630

Oda M, Saraya T, Wakayama M, Shibuya K, Ogawa Y, Ihui T, Yokoyama E, Inoue M, Shimayamada H, Fujiwara M, Ota T, Takizawa H, Goto H (2013) Calcium oxalate crystal deposition in a patient with aspergilloma due to Aspergillus niger. J Thorac Dis 5:E174-E178

Ohmomo S, Sugita M, Abe M (1973) Isolation of cyclopiazonic acid, cyclopiazonic acid imine and bissecodehydrocyclopiazonic acid from the cultures of Aspergillus versicolor (Vuill.) Tiraboschi. J Agric Chem Soc Japan 47:57-93

Ohta A, Ohta M (1983) Synthesis of mutaaspergillic and dlhydroxyaspergillic acids. Chem Pharm Bull 31:20-24

Orth R (1977) Mycotoxins of Aspergillus oryzae strains for use in the food industry as starters and enzyme producing strains. Ann Nutr Aliment 31:617-624

Ovenden SPB, Sberna G, Tait RM, Wildman HG, Patel R, Li B, Steffy K, Nguyen N, Meurer-Grimes BM (2004) A diketopiperazine dimer from a marine-derived isolates of Aspergillus niger. J Nat Prod 67: 2093-2095

Park H-S, Jun S-C, Han K-H, Hong S-B, Yi J-H (2017a) Diversity, application, and synthetic biology of industrially important Aspergillus fungi. Adv Appl Microbiol 100:161-202

Park SY, Oh HH, Park YL, Yu HM, Myung DS, Ch SB, Lee WS, Park D, Joo YE (2017b) Malformin A1 treatment alters invasive and oncogenic phenotypes of human colorectal cancer cells through stimulation of the p38 singaling pathway. Int J Oncol 51:959-966

Parrish FW, Wiley BJ, Simmons EG, Lang L (1966) Production of aflatoxins and kojic acid by species of Aspergillus and Penicillium. Appl Microbiol 14:139

Patron NJ, Waller RF, Cozijnsen AJ, Straney DC, Gardiner DM, Nierman WC, Howlett BJ (2007) Origin and distribution of epipolythiodioxopiperazine (ETP) gene clusters in filamentous ascomycetes. BMC Evol Biol 7:174

Pattenden G (1969) Synthesis of asperenone, a new pigment from Aspergillus niger and Aspergillus awamori. Tetrahedron Lett 9: 4049-4052

Pattenden G (1970) Synthesis of asperenone [all-trans(E)-8-methyl-13phenyltrideca-4,6,8,10,12-pentaen-3-one], a pigment of Aspergillus species of fungi. J Chem Soc (C) 1970:1404-1409 
Payne GA, Nierman WC, Wortman JR, Pritchard BL, Brown D, Dean RA, Bhatnagar D, Cleveland TE, Machida M, Yu Y (2006) Whole genome comparison of Aspergillus flavus and A. oryzae. Med Mycol 44:S9-S11

Pel HJ, van de Winde JH, Archer DB, Dyer PS, Hofmann G, Schaap PJ, Turner G, de Vries RP, Albang R, Alberman K, Andersen MR, Bendtsen JD, Benen JA, van den Berg M, Breetstraat S, Caddick MS, Contreras R, Cornell M, Coutinho PM, Dancnin EG, Debets AJ, Dekker P, van Dijck PW, van Dijk A, Dijkhuizen L, Driessen AJ, d'Enfert C, Geysens S, Goosen C, Groot GS, de Groot PW, Guillemette T, Henrissat B, Herweijer M, van den Homberg JP, van den Hondel CA, van der Heijden RT, van der Kaaij RM, Klis FM, Kools HJ, Kubicek CP, van Kuyk PA, Lauber J, Lu X, van der Marel MJ, Meulenberg R, Menke H, Mortimer MA, Nielsen J, Oliver SG, Olsthoorn M, Pal K, van Peij NN, Ram AF, Rinas U, Troubos JA, Sagt CM, Schmoll M, Sun J, Ussery D, Varga J, Vervecken W, van de Vondervoort PJ, Wedler H, Wosten HA, Zeng AP, van Oorwen AJ, Visser J, Stam H (2007) Genome sequencing and analysis of the versatile cell factory Aspergillus niger CBS 513.88. Nat Biotechnol 25:221-231

Perrone G, Stea G, Epifani F, Varga J, Frisvad JC, Samson RA (2011) Aspergillus niger contains the cryptic phylogenetic species $A$. awamori. Fungal Biol 115:1138-1150

Perry MJ, Makins JF, Adlard MW, Holt G (1984) Aspergillic acids produced by mixed cultures of Aspergillus flavus and Aspergillus nidulans. J Gen Microbiol 130:319-323

Petersen LM, Holm DK, Knudsen PB, Nielsen KF, Gotfredsen CH, Mortensen UH, Larsen TO (2015) Characterization of four new yanuthones from Aspergillus niger. J Antibiot 68:201-205

Pfefferle W, Anka H, Bross M, Steffan B, Vianden R, Steglich W (1990) Asperfuran, a novel antifungal metabolite from Aspergillus oryzae. $\mathrm{J}$ Antibiot 43:648-654

Pinheiro EAA, Carvalho JM, dos Santos DCP, Feitosa AD, Marinho PSB, Guilhon GMSP, de Souza ADL, da Silva FMA, Marinho AMD (2013) Antibacterial activity of alkaloids produced by endophytic fungus Aspergillus sp EJC08 isolated from medical plant Bauhinia guianensis. Nat Prod Res 27:1633-1638

Pitt JI, Hocking AD, Glenn DR (1983) An improved medium for the detection of Aspergillus flavus and Aspergillus parasiticus. J Appl Bacteriol 54:109-114

Plattner PA, Clauson-Kaas N (1945) Über ein Welke erzeugendes Stoffwechselproducte von Fusarium lycopersici Sacc. Helv Chim Acta 28:188-195

Pócsfalvi G, Ritieni A, Ferranti P, Randazzo G, Vékey K, Malorni A (1997) Microheterogeneity characterization of a paracelsin mixture from Trichoderma reesei using high-energy collision-induced dissociation tandem mass spectrometry. Rap Commun Mass Spectrom 11:922-930

Pontovich VE (1943) Aspergillus flavus as a source of flavin. Biokhimiya 8:297-301

Powell AJ, Conant CC, Brown DE, Carbone I, Dean RA (2008) Altered patterns of gene duplication and differential gene gain and loss in fungal pathogens. BMC Genomics 9:147

Poulsen L, Andersen MR, Lantz AE, Thykaer J (2012) Identification of a transcription factor controlling $\mathrm{pH}$-dependent organic response in Aspergillus niger. PLoS ONE 7:e50596

Price MN, Dehal PS, Arkin AP (2009) FastTree: computing large minimum evolution trees with profiles instead of a distance matrix. Mol Biol Evol 26:1641-1650

Priegnitz B-E, Brandt U, Pahirulzaman AK, Dickschat JS, Fleissner A (2015) The AngFus3 mitogen-activated protein kinase controls hyphal differentiation and secondary metabolism in Aspergillus niger. Euk Cell 14:602-615

Przybylski M, Dietrich I, Manz I, Brückner H (1984) Elucidation of structure and microheterogeneity of the polypeptide antibiotics paracelsin and trichotoxin A-50 by fast atom bombardment mass spectrometry in combination with selective in situ hydrolysis. Biomed Mass Spectrom 11:569-582

Purchase IFH (1971) The acute toxicity of the mycotoxin cyclopiazonic acid to rats. Toxicol Appl Pharmacol 18:114-123

Purchase IFH, Theron JJ (1968) The acute toxicity of ochratoxin A to rats. Food Cosmet Toxicol 6:479-480

Qiao M-F, Ji N-Y, Liu X-H, Li F, Xue Q-Z (2010a) Asporyergosterol, a new steroid from an algicolous isolate of Aspergillus oryzae. Nat Prod Commun 5:1575-1578

Qiao M-F, Ji N-Y, Liu X-H, Li K, Zhu Q-M (2010b) Indoloterpenes from an algicolous isolate of Aspergillus oryzae. Bioorg Med Chem Lett 20:5677-5680

Qiao M-F, Ji N-Y, Miao F-P, Yin X-L (2011) Steroids and an oxylipin from an algicolous isolate of Aspergillus flavus. Magn Res Chem 49:366-369

Rabache M, Neuman J, Lavollay J (1974) Phenylpolyenes d'Aspergillus niger: structure et proprietes de l'asperrubrol. Phytochem 13:637642

Rahssaparpoor P (2014) An investigation on the patterns of deoxunivalenol (DON) mean values in Aspergillus isolates, based on subgenus and species correlations. Ind J Fund Appl Life Sci 4: $143-154$

Raistrick H, Clark AB (1919) On the mechanism of oxalic acid formation by Aspergillus niger. Biochem J 13:329-344

Ramakrishnan CV, Desai PJ (1956) Effect of addition of iron, cobalt, and ascorbic acid to the medium on the synthesis of ascorbic acid in molds. Curr Sci (India) 25:189-190

Ramakrishnan CV, Sathe V (1956) Effect of vitamin $\mathrm{K}_{3}$ on inducing its biosynthesis in moulds. Sci Cult (Calcutta) 22:340

Rand TG, Chang CT, McMullin DR, Miller JD (2017) Inflammationassociated gene expression in RAW 264.7 macrophages induced by toxins from fungi common on damp building materials. Toxicol in Vitro 43:16-20

Rank C, Klejnstrup ML, Petersen LM, Kildegaard S, Frisvad JC, Gotfredsen CH, Larsen TO (2012) Comparative chemistry of Aspergillus oryzae (RIB40) and A. flavus (NRRL 3357). Metabolites 2:39-56

Rao KCS, Divakar S, Babu KN, Rao AGA, Karanth NG, Sattur AP (2002a) Nigerloxin, a novel inhibitor of aldose reductase and lipoxygenase with free radical scavenging activity from Aspergillus niger CFR-W-105. J Antibiot 55:789-793

Rao KCS, Divakar S, Rao AGA, Karanth NG, Suneetham WJ, Krishnakantha TP, Sattur AP (2002b) Asperenone: an inhibitor of 15-lipoxygenase and of human platelet aggregation from Aspergillus niger. Biotechnol Lett 24:1967-1970

Rao KCS, Karanth NG, Sattur AP (2005) Production of nigerloxin, an enzyme inhibitor and a free radical scavenger, by Aspergillus niger using solid state fermentation. Proc Biochem 40:2517-2522

Raper KB (1946) The development of improved penicillin-producing molds. Ann NY Acad Sci 48:41-52

Raper KB, Fennell DI (1965) The genus Aspergillus. Williams and Wilkins, Baltimore

Ray AC, Eakin RE (1975) Studies on the biosynthesis of aspergillin by Aspergillus niger. Appl Microbiol 30:909-915

Ren R, Chen C-J, Hu S-S, Ge H-M, Zhu W-Y, Tan R-X, Jiao R-H (2015) Drimane sesquiterpenoids from the Aspergillus oryzae QXPC-4. Chem Biodiv 12:371-379

Robert M, Barbier M, Lederer E, Roux L, Biemann K, Vetter W (1962) Two new natural phytotoxins: Aspergillomarasmines A and B and their identity to lycomarasmine and its derivatives. Bull Soc Chim Fr 1962:187-188

Rodricks JV, Lustig E, Campbell AD, Stoloff L (1968) Aspertoxin, a hydroxyl derivative of O-methylsterigmatocystin from aflatoxin producintg cultures of Aspergillus flavus. Tetrahedron Lett 9: 2975-2978 
Rodrigues BSF, Sahm BDB, Jimenez PC, Pinto FCL, Mafezoli J, Mattos MC, Rodrigues-Filho E, Pfenning LH, Abreau LM, Costa-Lotufo LV, Oliveira MCF (2015) Bioprospection of cytotoxic compounds in fungal strains recovered from sediments of the Brazilian coast. Chem Biodiv 12:432-442

Rodriguez RLM, Konstantinidis KT (2014) Bypassing cultivation to identify bacterial species. Microbe 9:111-118

Rodríguez A, Rodríguez M, Luque MI, Martín A, Córdoba JJ (2012) Real-tine PCR assays for detection and quantification of aflatoxinproducing molds in foods. Food Microbiol 31:89-99

Rokas A (2009) The effect of domestication on the fungal proteome. Trends Genet 23:60-63

Rokas A, Payne G, Fedorova ND, Baker SE, Machida M, Yu J, Georgianna DR, Dean RA, Bhatnagar D, Cleveland TE, Wortman JR, Maiti R, Joardar V, Denning DW, Nierman WC (2007) What can comparative genomics tell us about species concepts in the genus Aspergillus? Stud Mycol 59:11-17

Saito K (1907) Über die Säurebildung bei Aspergillus oryzae. Botan Mag (Tokyo) 21:7-11

Saito M, Tsuruta O (1993) A new variety of Aspergillus flavus from tropical soil in Thailand and its aflatoxin productivity. Proc Jpn Assoc Mycotoxicol 37:31-36

Sakaguchi K, lizuka H, Yamazaki S (1951) A study on the black aspergilli. J Agric Chem Soc Japan 24:138-142

Sakaguchi K, Takahashi H, Morino H (1953) Production of $\alpha$ ketoglutaric acid by molds. J Agr Chem Soc Japan 27:591-595

Sakai H (1953) On vitamin $B_{12}$ production by fermentation. Part. 2. Production test of $\mathrm{B}_{12}$ by various microorganisms. J Agr Chem Soc Japan 27:405-407

Sakai K, Kinioshita H, Shimuzu T, Nihira T (2008) Construction of a citrinin gene cluster expression system in heterologous Aspergillus oryzae. J Biosci Bioeng 106:466-472

Sakata K, Kuwatsuka T, Sakurai A, Takahashi N, Tamura G (1983) Isolation of aspirochlorine (= antibiotic A 30641) as a true antimicrobial constituent of the antibiotic oryzachlorin, from Aspergillus oryzae. Agric Biol Chem 47:2673-2674

Sakata K, Maruyama M, Uzawa J, Sakurai A, Lu HSM, Clardy J (1987a) Structural revision of aspirochlorine (= antibiotic A 30641), a novel epidithiopiperazine-2,5-dione produced by Aspergillus spp. Tetrahedron Lett 28:5607-5610

Sakata K, Masago H, Sakurai A, Takahashi N (1982) Isolation of aspirochlorine (= antibiotic A 30641) possessing a novel dithiodiketopiperazine structure from Aspergillus flavus. Tetrahedron Lett 23:2095-2098

Sakata K, Masahito M, Kuwatsuka T, Uzawa J, Sakurai A, Lu HSM, Clardy J (1987b) Structure of aspirochlorine, a novel epidithiopiperazine-2,5-dione, and related compounds produced by Aspergillus spp. 29th Symp Chem Nat Prod 29:685-691

Saldan NC, Almeida RTR, Avíncola A, Porot C, Galuch MB, Magon TFS, Pilau EJ, Svidzinski TIE, Oliveira CC (2018) Development of an analytical method for identification of Aspergillus flavus based on chemical markers using HPLC-MS. Food Chem 241:113-121

Samson RA, Hong S-B, Peterson SW, Frisvad JC, Varga J (2007) Polyphasic taxonomy of Aspergillus section Fumigati and its teleomorph Neosartorya. Stud Mycol 59:147-203

Samson RA, Visagie CM, Houbraken J, Hong S-B, Hubka V, Klaassen CHW, Perrone G, Seifert KA, Susca A, Tanney JB, Varga J, Kocsubé S, Szigeti G, Yaguchi T, Frisvad JC (2014) Phylogeny, identification and nomenclature of the genus Aspergillus. Stud Mycol 78:141-173

Samuels GJ, Ismaiel A, Mulaw TB, Szakacs G, Druzhinina IS, Kubicek CP, Jaklitsch WM (2012) The Longibrachiatum clade of Trichoderma: a revision with new species. Fungal Divers 55:77-108

Samuels GJ, Petrini O, Kuhls K, Lieckfeldt E, Kubicek CP (1998) The Hypocrea schweinitzii complex and Trichoderma sect. Longibrachiatum. Stud Mycol 41:1-54
Sano Y, Ishikawa TY, Muramatsu S, Uzuka Y, Kokubo S, Omata S, Kitamura T, Matsugo S (2007) Study on the Koji mold producing substrate - possible application as a food supplement. Food Sci Technol 13:13-19

Sasaki M, Asoa Y, Yokotsuka T (1968) Studies of the compounds produced by molds part V. Isolation of non-fluorescent pyrazine compounds (2). J Agric Chem Soc Jpn 42:351-355 (in Japanese)

Sato N, Horiuchi T, Hamano M, Sekine H, Chiba S, Yamamoto H, Yoshioka T, Kimura I, Satake M, Ida Y (1996) Kojistatin A, a new cysteine protease inhibitor produced by Aspergillus oryzae. Biosci Biotech Biochem 60:1747-1748

SCCS (Scientific Committee on Consumer Safety) (2012) Opinion on kojic acid, 26-27 June 2012.

Schlingmann G, Taniguchi T, He H, Bigelis R, Yang HY, Koehn FE, Carter GT, Berova N (2007) Reassessing the structure of pyranonigrin. J Nat Prod 70:1180-1187

Schmoll M, Dattenböck C, Carreras-Villaseñor N, Mendoza-Mendoza A, Tisch D, Alemán MI, Baker SE, Brown C, Cervantes-Badillo MG, Cetz-Chel J, Cristobal-Mondragon GR, Delaye H, Esquivel-Naranjo EU, Frischmann A, Gallardo-Negrete JD, Garca-Esquivel M, Gomez-Rodriguez E, Greenwood DR, Hernandez-Onata M, Kruszewska JS, Lawrey R, Mora-Montes HM, Munoz-Centeno T, Nieto-Jacobo MF, Lopez GN, Olmedo-Nonfil V, OsoroaConceosion M, Pilsyk S, Pomraning KR, Rodriguez-Iglesias A, Rosales-Saavedra MT, Sanchez-Arregyúin JA, Sedl-Seiboth V, Stewart A, Iresti-Rivera EE, Wang CL, Wang TF, Zeilinger S, Casas-Flores S, Herrera-Estrella A (2016) The genomes of three uneven siblings: Footprints of the lifestyles of three Trichoderma species. Microbiol Mol Biol Rev. 80:205-327

Schroeder HW, Kelton WH (1975) Production of sterigmatocystin by some species of the genus Aspergillus and its toxicity to chicken embryos. Appl Microbiol 30:589-591

Schuster E, Dunn-Coleman N, Frisvad JC, van Dijck PWM (2002) On the safety of Aspergillus niger-a review. Appl Microbiol Biotechnol 59:426-435

Seshime Y, Juvvadi PR, Fujii I, Kitamoto K (2005) Discovery of a novel superfamily of type III polyketide synthases in Aspergillus oryzae. Biochem Biophys Res Commun 331:253-260

Seshime Y, Juvvadi PR, Kitamoto K, Ebizuka Y, Fujii I (2010b) Identification of csypyrone B1 as the novel product from Aspergillus oryzae type III polyketide synthase CsyB. Biomed. Med Chem 18:4542-4546

Seshime Y, Juvvadi PR, Kitamoto K, Ebizuka Y, Nonaka T, Fujii I (2010a) Aspergillus oryzae type III polyketide synthase csyA is involved in the biosynthesis of 3,5-dihydroxy-benzoic acid. Biomed. Med Chem Lett 20:4785-4788

Shaaban M, El-Metwally MM, Nasr H (2014) A new diketopiperazine alkaloid from Aspergillus oryzae. Nat Prod Res 28:86-94

Shen L, Ye Y-H, Wang X-T, Zhu H-L, Xu C, Song YC, Li H, Tan R-X (2006) Structure and total synthesis of aspernigerin: a novel cytotoxic endophyte metabolite. Chem Eur J 2006:4393-4396

Shi YS, Zhang Y, Chen XZ, Zhang N, Liu YB (2015) Metabolites produced by the endophytic fungus Aspergillus fumigatus from the stem of Erythrophloeum fordii Oliv. Molecules 20:10793-10799

Shigehisa H, Kikuchi H, Suzuki T, Hiroya K (2015) The revised structure of trichodermatide A. Eur J Org Chem 2015:7670-7673

Shimizu Y, Ogata H, Goto S (2017) Type III polyketide synthases: functional classification and phylogenomics. ChemBioChem 18:50-65

Shimoda C (1951) An antibacterial substance, oryzacidin, against sakeputryfying bacteria, produced by Aspergillus oryzae. J Agric Chem Soc Japan 25:254-260

Shinohara Y, Kawatani M, Futamura Y, Osada H, Koyama Y (2016) An overproduction of astellolides induced by genetic disruption of chromatin-remodeling factors in Aspergillus oryzae. J Antibiot 69: 4-8 
Shiomi K, Hatae K, Yamaguchi Y, Masuma R, Tomoda H, Kobayashi S, Omura S (2002) New antibiotics miyakamides produced by a fungus. J Antibiot 55:952-961

Shishido K, Omodani T, Shibuya M (1991) Novel and enantioselective total synthesis of drimane type sesquiterpenes. J Chem Soc Perkin Trans 1(1991):2285-2287

Shu Y-Z, Cutrone JQ, Klohr SE, Huang S (1995) BMS-192548, a tetracyclic binding inhibitor of neuropeptide $\mathrm{Y}$ receptors, from Aspergillus niger WB2346. II Physicochemical properties and structural characterization. J Antibiot 48:1060-1065

Skóra J, Sulyok M, Nowak A, Otlewska A, Gutarowska B (2017) Toxinogenicity and cytotoxicity of Alternaria, Aspergillus and Penicillium moulds isolated from working environments. Int $\mathrm{J}$ Environ Sci Technol 14:595-608

Son SY, Lee S, Singh D, Lee N-R, Lee D-Y, Lee CH (2018) Comprehensive secondary metabolite profiling toward delineating the solid and submerged-state fermentation of Aspergillus oryzae KCCM 12698. Front Microbiol 9 Art 1076

Sørensen LM, Lametsch R, Andersen MR, Nielsen PV, Frisvad JC (2009) Proteome analysis of Aspergillus niger: lactate added in starchcontaining medium can increase production of the mycotoxin fumonisin $\mathrm{B}_{2}$ by modifying acetyl-CoA metabolism. BMC Microbiol 9:255

Springer JP, Büchi G, Kobbe B, Demain AL, Clardy J (1977) The structure of ditryptophenaline - a new metabolite of Aspergillus flavus. Tetrahedron Lett 18:2403-2406

Srinisavan KS, Ramakrishnan CV (1952) Synthesis of thiamine by molds. Biochem Biophys Acta 9:156-160

Stockmann-Juvala H, Savolainen K (2008) A review of the toxic effects and mechanisms of action of fumonisin $\mathrm{B}_{1}$. Hum Exp Toxicol 27: 799-809

Sugawara F, Kim K-W, Uzawa J, Yoshida S, Takahashi N, Curtis RW (1990) Structure of malformin $\mathrm{A}_{2}$, reinvestigation of phytotoxic metabolites produced by Aspergillus niger. Tetrahedron Lett 31:43374340

Sugimoto T, Murata S, Matsuura S, Pfleiderer W (1986) Synthesis of asperopterin B and some analogues. Tetrahedron Lett 27:4179-4180

Sugiyama M, Masaki M, Ohta M (1967) Synthesis of 1-hydroxy-3isobutyl-6-(1-hydroxy-1-methylethyl)-2-pyrazinone and the structure of muta-aspergillic acid. Tetrahedron Lett 8:845-848

Sun Y, Laian T, Huangn J, Ma H-Y, Lv A-L, Yasukawa K, Pei Y-H (2008) Trichodermatides A-D, novel polyketides from the marine-derived fungus Trichoderma reesei. Org Lett 10:393-396

Sun K, Li Y, Guo L, Wang Y, Liu P, Zhu W (2014) Indole diterpenoids and isocoumarin from the fungus Aspergillus flavus, isolated from the prawn, Penaeus vannamei. Mar Drugs 12:3970-3981

Suresha BS, Srinivasan K (2013) Antioxidant properties of fungal metabolite nigerloxin in vitro. Appl Biochem Microbiol 49:587-591

Susca A, Proctor RH, Butchko RAE, Haidukowski M, Stea G, Logrieco A, Moretti A (2014) Variation in the fumonisin biosynthetic gene cluster in fumonisin-producing and nonproducing black aspergilli. Fungal Genet Biol 73:39-52

Taevernier L, Wynendaele E, de Vreese L, Burvenich C, de Spiegeleer B (2016) The mycotoxin definition reconsidered towards fungal cyclic depsipeptides. J Environ Sci Health, Part C 34:114-135

Tagami K, Minami A, Fujii R, Liu C, Tanaka M, Gomi K, Dairi T, Oikawa H (2014) Rapid reconstruction of biosynthetic machinery of fungal metabolites in Aspergillus oryzae: total biosynthesis of aflatrem. ChemBioChem 15:2076-2080

Takagi M, Motohashi K, Hwang J-H, Nagai A, Shin-ya K (2010) New tensidols, JBIR-86 and JBIR-87, isolated from Aspergillus sp. fJ80. J Antibiot 63:371-373

Takahashi T, Jin FJ, Sunagawa M, Machida M, Koyama Y (2008) Generation of large chromosomal deletions in koji molds Aspergillus oryzae and Aspergillus sojae via loop-out recombination. Appl Environ Microbiol 74:7684-7693
Takahashi T, Ogawa M, Koyama Y (2012) Analysis of the functions of recombination-related genes in the generation of large chromosomal deletions by loop-out recombination in Aspergillus oryzae. Euk Cell 11:507-517

Talontsi FM, Tatong MD, Dittrich B, Douanla-Meli C, Laatsch H (2013) Structures and absolute configuration of three $\alpha$-pyrones from an endophytic fungus Aspergillus niger. Tetrahedron 69:7147-7151

Tamiya H (1927) Studien über die Stoffwechselprodukte von Aspergillus oryzae. I. Metabolic physiology of Aspergillus oryzae. I. Acta Phytochim Jpn 3:51-173

Tamogami S, Katayama M, Marumo S, Isobe M (1996) Synthesis of the 5-demethyl-6-deoxy analogue of sporogen AO1, a sporogenic substance of Aspergillus oryzae. Biosci Biotech Biochem 60:13721374

Tan Q-W, Gao F-L, Wang F-R, Chen Q-J (2015) Anti-TMV activity of malformin $\mathrm{A}_{1}$, a cyclic penta-peptide produced by an endophytic fungus Aspergillus tubingensis FJBJ11. Int J Mol Sci 16:5750-5761

Tanabe M, Hamasaki T, Suzuki Y, Johnson LF (1973) Biosynthetic studies with carbon-13: Fourier nuclear magnetic resonance spectra of the metabolite avenaciolide. J Chem Soc Chem Commun 1973: 212-213

Tanaka K, Goto T, Manabe M, Matsuura S (2002) Traditional japanese fermented foods free from mycotoxin contamination. Jpn Agric Res Quart 236:45-50

Tanaka T, Hasegawa A, Aoki N, Yamamoto S, Udagawa S, Sekita S, Harada M, Nozawa K, Kawai K (1989) Production of aflatrem and its related indoloterpenes by microsclerotium-producing strains of Aspergillus flavus. Proc Jpn Assoc Mycotoxicol 30:19-23

Tanaka S, Wada K, Katayama M, Marumo S (1984a) Isolation of sporogen-AO1, a sporogenic substance from Aspergillus oryzae. Agric Biol Chem 48:3189-3191

Tanaka S, Wada K, Marumo S, Hattori H (1984b) Structure of sporogenAO1, a sporogenic substance. Tetrahedron Lett 25:5907-5910

Tang M-C, Lin H-C, Li D, Zou Y, Li J, Xu W, Cacho RA, Hillenmeyer ME, Garg NK, Tang Y (2015) Discovery of unclustered fungal indole diterpene biosynthetic pathways through combinatorial pathway reassembly in engineered yeast. J Am Chem Soc 137:13724 13727

Tao L, Chung SH (2014) Non-aflatoxigenicity of commercial Aspergillus oryzae strains due to genetic defects compared to aflatoxigenic strains. J Microbiol Biotechnol 24:1081-1087

TePaske MR, Gloer JB, Wicklow DT, Dowd PF (1990) Aflavazole: a new antiinsectan carbazole metabolite from the sclerotia of Aspergillus flavus. J Org Chem 55:5299-5301

TePaske MR, Gloer JB, Wicklow DT, Dowd PF (1991) Leporin A - an antiinsectan N-alkoxypyridone from the sclerotia of Aspergillus leporis. Tetrahedron Lett 32:5687-5690

TePaske MR, Gloer JB, Wicklow DT, Dowd PF (1992) Aflavarin and beta-aflatrem - new anti-insectan metabolites from the sclerotia of Aspergillus flavus. J Nat Prod 55:1080-1086

Terabayashi Y, Sano M, Yamane N, Maruui J, Tamano K, Sagara J, Dohmoto M, Oda K, Ohshima E, Tachibana K, Higa Y, Ohashi S, Koike H, Machida M (2010) Identification and characterization of genes responsible for biosynthesis of kojic acid, an industrially important compound from Aspergillus oryzae. Fungal Genet Biol 47: 953-961

Thom C, Church MB (1921) Aspergillus flavus, A. oryzae, and associated species. Amer J Bot 8:103-126

Tokuoda M, Seshime Y, Fujii I, Kitamoto K, Takahashi T, Koyama Y (2008) Identification of a novel polyketide synthase-nonribosomal peptide synthase (PKS-NRPS) gene required for the biosynthesis of cyclopiazonic acid in Aspergillus oryzae. Fungal Genet Biol 45: $1608-1615$

Tokuoka M, Kukuchi T, Shinohara Y, Koyama A, Iio S, Kubota T, Kabayashi J, Kayama A, Shindo H, Sato K (2015) Cyclopiazonic 
acid biosynthesis gene cluster cpaM is required for speradine A biosynthesis. Biosci Biotechnol Biochem 79:2081-2085

Tominaga M, Lee Y-H, Hayashi R, Suzuki Y, Yamada O, Sakamoto K, Gotoh K, Akita O (2006) Molecular analysis of an inactive aflatoxin biosynthesis gene cluster in Aspergillus oryzae RIB strains. Appl Environ Microbiol 72:484-490

Torres J, Guarro J, Suarez G, Sune N, Ramírez C (1980) Morphological changes in strains of Aspergillus flavus Link ex Fries and Aspergillus parasiticus Speare related with aflatoxin production. Mycopathologia 72:171-174

Tsuda M, Mugishima T, Komatus K, Sone T, Tanaka M, Mikami Y, Shiro M, Hirai M, Ohizumi Y, Kobayashi J (2003) Speradine A, a new pentacyclic oxindole alkaloid from a marine-derived fungus Aspergillus tamarii. Tetrahedron 59:3227-3230

Tsukui T, Nagano N, Umemura M, Kumagai T, Terai G, Machida M, Asai K (2015) Ustiloxins, fungal cyclic peptides, are ribosomally synthesized in Ustilaginoidea virens. Bioinformatics 31:981-985

Turner WB (1971) Fungal metabolites. Academic Press, London

Turner WB, Aldridge DC (1983) Fungal metabolites II. Academic Press, London

Uchoa PKS, Pimenta ATA, Braz-Filho R, de Oliveira M da CF, Saraiva NN, Rodrigues BSF, Pfenning LH, Abreau LM, Wilke DV, Florenciog KDG, Lima MAS (2017) New cytotoxic furan from the marine sediment-derived fungi Aspergillus niger. Nat Prod Res 31:2599-2603

Ueno T, Nishimura A, Yoshizako F (1977) Isolation and identification of a new analogue of aspergillic acid derived from valine and isoleucine. Agric Biol Chem 41:901-902

Ui H, Shiomi K, Yamaguchi Y, Masuma R, Nagamitsu T, Takano D, Sunazuka T, Namikoshi M, Omura S (2001) Nafuredin, a novel inhibitor of NADH-fumarate reductase, produced by Aspergillus niger FT-0554. J Antibiot 54:234-238

Uka V, Moore GG, Arroyo-Manzanares N, Nebija D, De Saeger S, Mavungu JDD (2017) Unravelling the diversity of the cyclopiazonic acid family of mycotoxins in Aspergillus flavus by UHPLC tripleTOF HRMS. Toxins 9:35

Umemura M, Koike H, Nagano N, Ishii T, Kawano J, Yamane N, Kozone I, Horimoto K, Shin-ya K, Asai K, Yu J, Bennett JW, Machida M (2013b) MIDDAS-M: Motif-independent de novo deetction of secondary metabolite gene clusters through the integration of genome sequencing and trinscriptome data. PLoS ONE 8:e84028

Umemura M, Koike H, Yamane N, Koyama Y, Satou Y, Kikuzato I, Teruya M, Tsukahara M, Imada Y, Wachi Y, Miwa Y, Yano S, Tamano K, Kawarabayasi Y, Fujimoro KE, Machida M, Hirano T (2012) Comparative genome analysis between Aspergillus oryzae strains reveals close relationship between sites of mutation localization and regions of highly divergent genes among Aspergillus species. DNA Res 19:375-382

Umemura M, Koyama Y, Takeda I, Hagiwara H, Ikegami T, Koike H, Machida M (2013a) Fine de novo sequencing of a fungal genome using only SOLiD short read data: verfication on Aspergillus oryzae RIB40. PLoS ONE 8:e63673

Umemura M, Nagano N, Koike H, Kawano J, Ishii T, Miyamura Y, Kikuchi M, Tamano K, Yu J, Shin-ya K, Machida M (2014) Characterization of the biosynthetic gene cluster for the ribosomally synthesized cyclic peptide ustiloxin B in Aspergillus flavus. Fungal Genet Biol 68:23-30

Umezawa H, Tobe H, Shibamoto N, Nakamura F, Nakamura K, Matzusaki M, Takeuchi T (1975) Isolation of isoflavones inhibiting DOPA decarboxylase from fungi and Streptomyces. J Antibiot 28: 947-952

Valdes JJ, Cameron JE, Cole RJ (1985) Aflatrem: a tremorgenic mycotoxin with acute neurotoxic effects. Environ Health Perspec 62:459 463

Van der Merwe KJ, Fourie L, Scott de B (1963) On the structure of the aflatoxins. Chem Ind 1963:1660-1661
Varga J, Due M, Frisvad JC, Samson RA (2007) Taxonomic revision of Aspergillus section Clavati based on molecular, morphological and physiological data. Stud Mycol 59:89-106

Varga J, Frisvad JC, Kocsubé S, Brankovics B, Tóth B, Szigeti G, Samson RA (2011a) New and revisited species in Aspergillus section Nigri. Stud Mycol 69:1-17

Varga J, Frisvad JC, Samson RA (2009) A reappraisal of fungi producing aflatoxin. World Mycotoxin J 2:263-277

Varga J, Frisvad JC, Samson RA (2011b) Two new aflatoxin producing species and an overview of Aspergillus section Flavi. Stud Mycol 69:57-80

Varoglu M, Corbett TH, Valeriote FA, Crews P (1997) Asperazine, a selective cytotoxic alkaloid from a sponge-derived culture of Aspergillus niger. J Org Chem 62:7078-7079

Varoglu M, Crews P (2000) Biosynthetically diverse compounds from a saltwater culture of sponge-derived Aspergillus niger. J Nat Prod 63: $41-43$

Vasantha KY, Singh RP, Sattur AP (2018) A preliminary pharmacokinetic and toxicity study of nigerloxin. Ind J Biochem Biophys 55:44-51

Vernot EH, MacEwen CC, Kinkead ER (1977) Acute toxicity and skin corrosion data for some organic and inorganic compounds and aqueous solutions. Toxicol Appl Pharmacol 42:417-423

Vesth TC, Nybo JL, Theobald S, Frisvad JC, Larsen TO, Nielsen KF, Hoof JB, Brandl J, Salamov A, Ryley R, Gladden JM, Phatale P, Nielsen MT, Lyhne EK, Kogle ME, Strasser K, McDonald E, Berrey K, Clun A, Chen C, Nolan M, Sandor L, Kuo A, Lipzen A, Hainaut M, Drula E, Tsang A, Magnuson JK, Henrissat B, Wiebenga A, Simmons BA, Mäkelä MR, de Vries RP, Grigoriev IV, Mortensen UH, Baker SE, Andersen MR (2018) Section-level genome sequencing of Aspergillus section Nigri to investigate inter- and intra-species variation. Nature Genetics in press

Vidal-Garcia M, Redrado S, Domingo MP, Marquina P, Colmemarejo C, Meis JF, Rezusta A, Pardo J, Galvez EM (2018) Production of the invasive aspergillosis biomarker bis(methylthio)gliotoxin within the genus Aspergillus: in vitro and in vivo metabolite quantification and genomic analysis. Front Microbiol 9:1246

Voss KA, Riley RT (2013) Fumonisin toxicity and mechanism action: overview and current perspectives. Food Saf 1:50-69

Wada K, Tanaka S, Marumo S (1983) Structures of two new sesquiterpenes from Aspergillus oryzae. Agric Biol Chem 47:1075-1078

Waiss AC, Wiley M, Black DR, Lundin RE (1968) 3-Hydroxy-6,7dimethoxydifuroxanthone-a new metabolite from Aspergillus flavus. Tetrahedron Lett 9:3207-3210

Waksman SA, Bugie E (1943) Strain specificity and production of antibiotic substances. II. Aspergillus flavus-oryzae group. Proc Nat Acad Sci U S A 29:282-288

Wang D, Bao Y-R, Yang X-X, Meng X-S, Chen G (2015) A new alkaloid from Penicillium dipodomyicola. Chem Nat Comp 51:733-735

Wang Y, Wang LQ, Liu F, Wang Q, Selvaraj JN, Xing FG, Zhao YJ, Liu Y (2016) Ochratoxin producing fungi, biosynthetic pathways and regulatory mechanisms. Toxins 8:83

Wani MA, Sanjana K, Kumar DM, Lal DK (2010) GC-MS analysis reveals production of 2-phenylethanol from Aspergillus niger endophytic in rose. J Basic Microbiol 50:110-114

Wasil Z, Huhnert E, Simpson TJ, Cox RJ (2018) Oryzines A \& B, maleidride congeners from Aspergillus oryae and their putative biosynthesis. J Fungi 4:96

Watts R, Dahiya J, Chanhary K, Tauro P (1988) Isolation of a new antifungal metabolite of Trichoderma reesei. Plant Soil 107:81-84

Wenke J, Anke H, Sterner O (1993) Pseurotin A and 8-Odemethylpseurotin A from Aspergillus fumigatus and their inhibitory activities on chitin synthase. Biosci Biotechnol Biochem 57:961964

White EC (1940) Bactericidal filtrates from a mold culture. Science 92: 127 
White EC, Hill JH (1943) Studies on antibacterial products formed by molds. I. Aspergillic acid, a product of a strain of Aspergillus flavus. J Bacteriol 45:433-444

Wicklow DT (1984) Adaptation in wild and domesticated yellow-green aspergilli. In: Kurata H, Ueno Y (eds) Toxigenic fungi-their toxins and health hazard. Elsevier, Amsterdam, pp 78-85

Wicklow DT, Cole RJ (1982) Tremorgenic indole metabolites and aflatoxins in sclerotia of Aspergillus flavus - an evolutionary perspective. Can J Bot 60:525-528

Wiemann P, Guo C-J, Palmer JM, Sekonyela R, Wang CCC, Keller NP (2013) Prototype of an intertwined secondary metabolite gene cluster. Proc Nat Acad Sci U S A 110:17065-17070

Wu Z-J, Ouyang M-A, Su R-K, Kuo Y-H (2008) Two new cerebrosides and anthraquinone derivatives from the marine fungus Aspergillus niger. Chin J Chem 26:759-764

Wu ZC, Williams LJ, Danischefsky SJ (2000) A tree-step entry to the aspirochlorine family of antifungal agents. Angew Chem Int Ed 39: 3866-3869

Xu X, Zhang X, Nong X, Wei X, Shuhua Q (2015) Oxindole alkaloids from the fungus Penicillium commune DFFSCS026 isolated from deep-sea-derived sediments. Tetrahedron 71:610-615

Yabuta T (1912) On kojic acid, a new organic acid produced by Aspergillus oryzae. J Coll Agr, Imp Univ Tokyo 5:51-58

Yabuta T (1922) A new organic acid (kojic acid) formed by Aspergillus oryzae. J Chem Soc 122:939-941

Yamada T, Hiratake J, Aikawa M, Suizu T, Saito Y, Kawato A, Suginami $\mathrm{K}$, Oda J (1998) Cysteine protease inhibitors produced by the industrial koji mold, Aspergillus oryzae O-1018. Biosci Biotechnol Biochem 62:907-914

Yamaji K, Fukushi Y, Hashidoko Y, Yoshida T, Tahara S (1999) Characterization of antifungal metabolites produced by Penicillium species isolated from seeds of Picea glehnii. J Chem Ecol 25:16431653

Yang X-L, Awakara T, Wakimoto T, Abe I (2014) Three acyltetronic acid derivatives: noncanonical cryptic polyketides from Aspergillus niger identified by genome mining. ChemBioChem 15:1578-1583

Yang G, Sandjo L, Yun K, Leutou AS, Kim GD, Choi HD, Kang JS, Hong J, Son BW (2011) Flavusides A and B, antibacterial cerebrosides from the marine-derived fungus Aspergillus flavus. Chem Pharm Bull 59:1174-1177

Yassin MA, El-Rahim A, El-Samawaty MA, Moslem AA, Al-Arfaj AA (2015) Coffee bean myco-contaminants and oxalic acid producing Aspergillus niger. Ital J Food Sci 27:1

Ye Y, Minami A, Igarashi Y, Izumikawa M, Umemura M, Nagano N, Machida M, Kawahara T, Shin-ya K, Gomi K, Oikawa H (2016) Unveiling the biosynthetic pathway of the ribosomally synthesized and post-translationally modified peptide ustiloxin B in filamentous fungi. Angew Chem Int Ed 55:8072-8075

Ye YH, Zhu HL, Song YC, Liu JY, Tan RX (2005) Structural revision of aspernigrin A, reisolated from Cladosporium herbarum IFB-E002. J Nat Prod 68:1106-1108

Yoshimi A, Umemura M, Nagano N, Koike H, Machida M, Abe K (2016) Expression if $u s t R$ and the Golgi protease KexB are required for ustiloxin B biosynthesis in Aspergillus oryzae. AMB Express 6:9

Yoshizawa T, Tsuchiya Y, Morooka N, Sawada Y (1975) Malformin $A_{1}$ as a mammalian toxicant from Aspergillus niger. Agric Biol Chem 39:1325-1326

Yu J, Tamura G, Takahashi N, Arima K (1967) Asperyellone, a new pigment of Aspergillus awamori. Agric Biol Chem 31:831-836
Zabala AO, Xu W, Chooi Y-H, Tang Y (2012) Charactrization of a silent azaphilone gene cluster from Aspergillus niger ATCC 1015 reveals a hydroxylation-mediate pyran-ring formation. Chem Biol 19:10491059

Zalesskaya MI (1950) Riboflavin formation in Aspergillus flavus mycelium grown in filtered cereal mashes. Mikrobiologiya 19:127-136

Zeilinger S, Gruber S, Bansal R, Mukherjee PK (2016) Secondary metabolism in Trichoderma - chemistry meets genomics. Fungal Biol Rev 30:74-90

Zeiliger S, Martin J-F, García-Estrada C (eds) (2015) Biosynthesis and molecular genetics of fungal secondary metabolites. vol. 2. Springer, New York

Zeringue HJ, Shih BY Jr, Moskos K, Grimm D (1999) Identification of the bright-greenish-yellow-fluorescence (BGY-F) compound on cotton lint associated with aflatoxin contamination in cottonseed. Phytochemistry 52:1391-1397

Zhang Y, Li X-M, Feng Y, Wang B-G (2010) Phenetyl- $\alpha$-pyrone derivatives and cyclodipeptides from a marine algous endophytic fungus Aspergillus niger EN-13. Nat Prod Res 24:1036-1043

Zhang Y, Li X-M, Proksch P, Wang B-G (2007b) Ergosterimide, a new natural Diels-Alder adduct of a steroid and maleimide in the fungus Aspergillus niger. Steroids 72:723-727

Zhang Y, Li X-M, Wang B-G (2007d) Nigerasperones A-C, new monomeric and dimeric naphtho- $\gamma$-pyrones from marine alga-derived endophytic fungus Aspergillus niger EN-13. J Antibiot 60:204-210

Zhang Y, Li XM, Wang CY, Wang BG (2007c) A new naphthoquinoneimide derivative from the marine algal-derived endophytic fungus Aspergillus niger EN-13. Chin Chem Lett 18:951953

Zhang S, Monahan BJ, Tkacz JS, Scott B (2004) Indole-diterpene gene cluster from Aspergillus flavus. Appl Environ Microbiol 70:68756883

Zhang Y, Wang S, Li X, Cui CM, Feng C, Wang BG (2007a) New sphingolipids with a previously unreported 9-methyl-C20sphingosine moiety from a marine algous endophytic fungus Aspergillus niger EN-13. Lipids 42:759-764

Zhao G, Yao Y, Chen W, Cao X (2013b) Comparison and analysis of the genomes of two Aspergillus oryzae strains. J Agric Food Chem 61: 7805-7809

Zhao G, Yao Y, Hou L, Wang C, Cao X (2014a) Draft genome sequence of Aspergillus oryzae 100-8, an increased acid protease production strain. Genome Announc 2: e00548-14

Zhao G, Yao Y, Hou L, Wang C, Cao X (2014b) Comparison of the genomes and transcriptomes associated with the different protease secretions of Aspergillus oryzae 100-8 and 3.042. Biotechnol Lett 36:2053-2058

Zhao G, Yao Y, Wang C, Hou L, Cao X (2013a) Comparative genomic analysis of Aspergillus oryzae strains 3.042 and RIB40 for soy sauce fermentation. Int J Food Microbiol 164:148-154

Zhao G, Yao W, Wang C, Hou L, Zeng B, Cao X (2012) Draft genome sequence of Aspergillus oryzae strain 3-042. Euk Cell 11:1178

Zhou X, Fang W, Tan S, Lin X, Xun T, Yang B, Liu S, Liu Y (2016) Aspernigrins with anti-HIV-1 activities from the marine-derived fungus Aspergillus niger SCSIO Jcsw6F30. Bioorg Med Chem Lett 26:361-365

Zhuravleva OI, Kirichuk NN, Denisenko VA, Dmetrenok PS, Pivkin MV, Afiatullov SS (2016) New kipukasin from marine isolate of the fungus Aspergillus flavus. Chem Nat Comp 52:266-268 